\title{
Short Mountain Landfill Gas Recovery Project
}

Stage 1: Environmental Assessment

Received by OST

JUL 211992

DOE/EA-0551 
1.0 PURPOSE AND NEED 1

2.0 ALTERNATIVES 2

2.1 No Action 2

2.2 Proposed Project. 3

2.3 Other Actions 8

3.0 ENVIRONMENTAL, IMPACTS OF THE PROPOSED ACTION AND

ALTERNATIVES 9

3.1 FROPOSED ACTION 9

$\begin{array}{ll}3.1 .1 & \text { Land Use } 9 \\ 3.1 .2 & \text { Vegetation } 10\end{array}$

3.1 .3 Water 10

3.1.4 Fish and Wildife 12

3.1 .5 Soils 12

3.1.6 Air Quality 13

3.1.7 Public Health and Safety 16

3.1 .8 Visual 17

3.1.9 Historic/Cultural 18

3.2 ALTERNATIVE OF NO ACTION 18

3.3 OTHER ACTIONS 18

4.O ENVIRONMENTAL CONSULTATION, REVIEW, AND PERMIT REQUIREMENTS 18

4. I NATIONAL ENVIRONMENTAL POLICY 18

4.2 ENDANGERED AND THREATENED SPECIES AND CRITICAL HABITAT 19

4.3 FISH AND WILDLIFE CONSERVATION 19

4.4 HERITAGE CONSERVATION 19

4.5 STATE, AREAWIDE, AND LOCAL PLAN AND PROGRAM CONSISTENCY 20

4.6 COASTAL ZONE MANAGEMENT CONSISTENCY 21

4.7 FLOODPLAIN MANAGEMENT 21

4.8 WETLANDS PROTECTION 21

4.9 FARMLANDS PROTECTION 21

4.10 RECREATION RESOURCES 22

4.11 GLOBAL WARMING 22

4.12 PERMITS FOR STRUCTURES IN NAVIGABLE WATERS 23

4.13 PERMITS FOR DISCHARGES INTO WATERS OF THE UNITED STATES 23

4.14 PERMITS FOR RIGHTS-OF-WAY ON PUBLIC LAND 23

4.15 POLLUTION CONTROL 24

4.15.1 Prevention control, and Abatement of Environmental Pollution 24

4.15.2 Compliance with the clean Air Act 24

4.15.3 Compliance with the Clean water Act 24

4.15.4 Solid and Hazardous Waste 24

4.15.5 Resource Conservation and Recovery 25

4.15.6 Noise Control Act 25

4.15.7 Safe Drinking Water Act 26

4.15.8 Pesticides 26

4.15.9 Toxic Substances Control Act 27

4.15.10 Federal Insecticide, Fungicide, and 
Rodenticide Act 27

4.15 .11 Asbestos 27

4.15.12 Comprehensive Environmental Response, Compensation and Liability Act 28

4.15 .13 Radon 28

5. 0 PERSONS AND AGENCIES CONSULTED 28

6.0 REFERENCES 29

APPENDIX A Figures

APPENDIX B Attachments

APPENDIX $C$ Maps

ATTACHMENT D Wetlands Delineation 


\subsection{PURPOSE AND NEED}

The Bonneville Power Administration (BPA), a Federal power marketing agency, has statutory responsibilities to supply electrical power to its utility, industrial, and other customers in the Pacific Northwest. BPA's latest load/resource balance forecast, shown in Figure 1, projects the capability of existing resources to satisfy projected Federal system loads. The forecast indicates a potential resource deficit. The underlying need for action is to satisfy BPA customers' demand for electrical power.

\section{Ficure 1: BPA Load/Resource Balance Forecast}

\section{REGIONAL FIRM ENERGY SURPLUSES/DEFICITS Assuming No Resource Acquisitions}

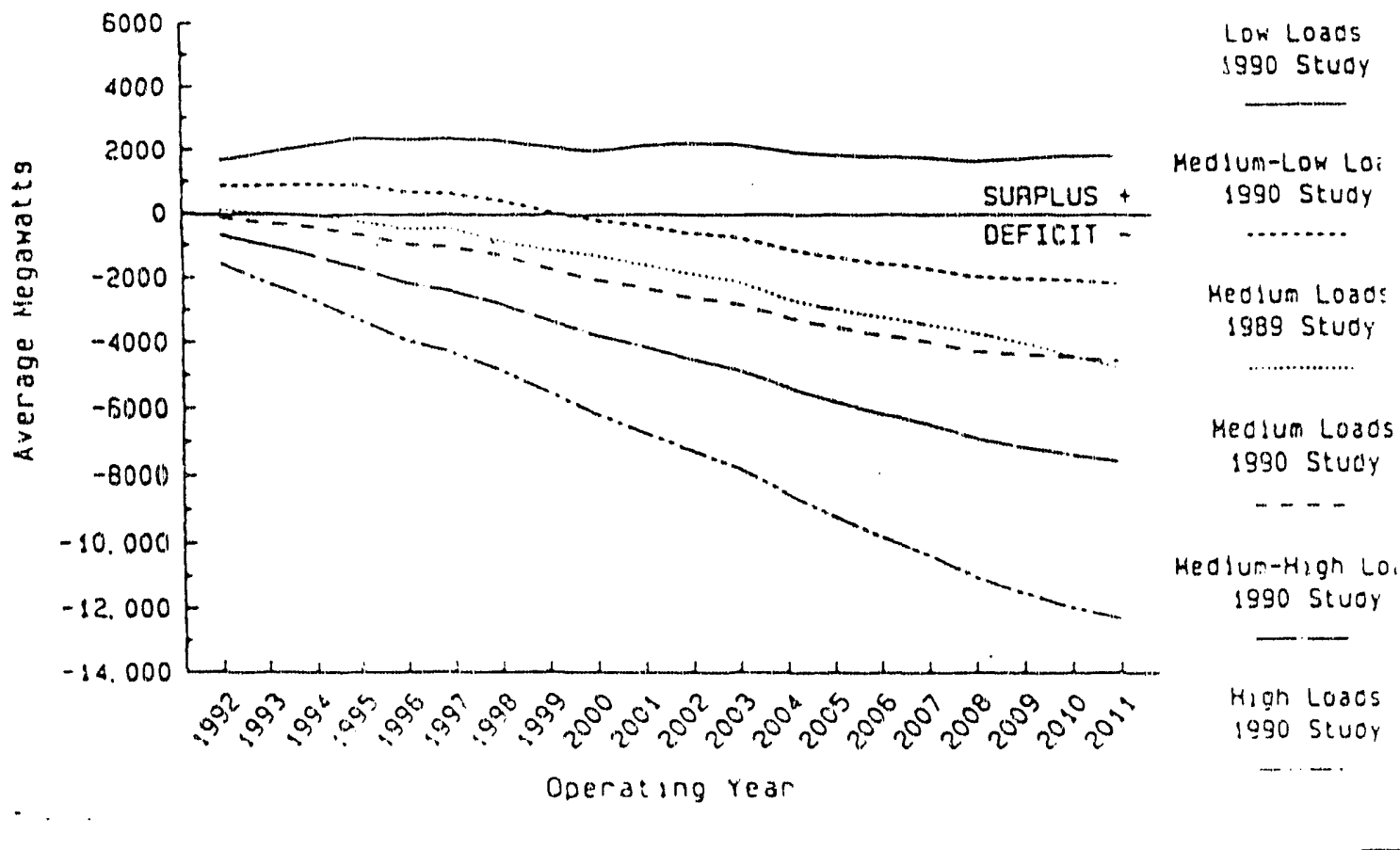


BPA's purposes in satisfying this need are to:

- Meet contractual obligations to supply requested, costeffective electric power to BPA customers;

- Assure consistency with BPA's statutory responsibilities, including the Pacific Northwest Electric Power Planning and Conservation Act (Northwest Power Act), while taking into consideration the Pacific Northwest Power Planning Council's Conservation and Electric Power Plan, and its Fish and Wildlife Program;

- Restore and enhance environmental quality, and avoid or minimize potential adverse environmental effects;

- Test implementation of BPA's Billing credits ${ }^{1}$ Policy (BPA, June 1982); and

-Efficiently administer BPA's Billing Credits Program.

\subsection{ALTERNATIVES}

\subsection{No Action}

Under this alternative, BPA would not grant a Billing credit for the proposed action, foregoing the opportunity to reduce BPA's projected energy deficit by approximately 1.5 firm megawatts annually. However, as Emerald People's Utility District (EPUD) decided to build the project independent of BPA's consideration to grant them a Billing credit ${ }^{2}$, the environmental impacts of the no action alternative are at least equal to the environmental impacts of the proposed action.

Ione method that BPA uses to acquire energy resources is Billing credits. With this innovative mechanism, authorized by the Northwest Power Act, BPA provides a credit to an eligible customer (utility, certain industries, and others) for load reduction actions and energy resource developments. Under BPA's 1990 Resource Program, BPA is seeking to test the Billing credits policy by acquiring up to 50 average megawatts; a solicitation for proposals was issued on July 9, 1990.

A complete description of the Billing credits policy is presented in an Environmental Assessment (EA) (DOE/EA-0180, June 1982), which has been made available to the public. The Billing Credit policy provides for site-specific National Environmental Policy Act (NEPA) review for each proposal after it is received (Billing Credit EA, page 5-2).

2upon submission of their proposal to BPA pursuant to the Billing credits Program, EPUD declared that the Project was financially viable with or without a Billing credit from BPA and, as such, would be constructed and operated prior to BPA completing its NEPA process. Further, EPUD does not need assistance from BPA in the form of transmission, wheeling, or other services in order to construct, operate, and maintain the project. Accordingly, BPA was placed in a position between wanting to implement its Billing 


\subsection{Proposed Action}

For this EA, BPA is considering awarding a Billing credit for the gas recovery project in its first stage of development. The proposed action would reduce, not eliminate, the need for power. EPUD is also planning a second stage of development. The second stage of development is not part of the Billing Credit proposal, and is independent of BPA's action. The short Mountain Landfill gas recovery project includes a generation plant that houses two 800-kilowatt internal combustion engines, and associated vertical and horizontal gas recovery wells located in two separate portions of the landfill. These wells are used to recover methane from the landfill that are used to run caterpillar (CAT) 3516 internal combustion engines to generate electricity. Short Mountain Landfill has been in operation since the late 1970 s and is expected to remain active for another 24 years (until 2016). EPUD's gas recovery project is expected to remain in operation for approximately 15 years beyond the life of the landfill. The project generates between 1.44 and 1.5 firm megawatts annually.

The Short Mountain Landfill is centrally located in oregon, approximately three miles north of the town of creswell and approximately seven miles south of Eugene and springfield (see Appendix C, Map A). Lane County owns the 580 acre landfill parcel which includes the project site. The project site (Section 36, Township 18 South, Range 3 West.) is bordered on the north by short Mountain, the west by Interstate 5 (I-5), the south by camas swale creek, and the east by the coast Fork willamette River.

Vertical wells: The landfill is being filled in six separate phases. There are fourteen vertical wells for the phase I cell of the landfill (see Appendix C, Map B). The maximum depth of garbage in this portion of the landfill is 150 feet. EPUD has drilled fourteen two foot diameter wells to a depth of one foot above the bottom of the landfill. The wells vary in depth from 35 feet to 85 feet depending on where trey are located on the landfill. Auger material from the drilling is disposed of in an active phase of the landfill. A six inch diameter high density

2 (cont.)credits policy only for environmentally sound projects and, as ultimately evinced by EPUD's action to construct the facility prior to a decision by BPA as to whether a Billing credit would be granted, having no control over the applicant's decision to develop the project. Consequently, BPA decided, consistent with CEQ's implementing regulations for NEPA, 40 C.F.R. section $1501.3(b)$, and BPA's programmatic NEPA document regarding the Billing Credit Policy, Billing Credit Policy EA at 5-2, to prepare an EA on the project in order to assist the agency in decisionmaking. However, as BPA's Billing credit is not enabling the Project, a NEPA document was not statuturily required. 
polyethylene (HDPE) pipe is centered into the kell (down to one foot above the bottom of the well) and the rest of the well is backfilled with specified materials (see Appendix A, Figure 1). The top five feet of backfill material consists of native material followed by two feet of bentonite clay to provide a seal that prevents gases from leaking upward and out of the well. The next two feet of backfill material consists of sand underlain by coarse (one to one and a half inches) gravel down to the bottom of the well. The six inch HDPE vertical wells are perforated with $5 / 8$ inch diameter holes beginning one foot below the top of the gravel. The perforated portion of the pipe contains approximately 18 evenly spaced holes per foot. The bottom of the pipe is capped.

Approximately three feet of the wellhead is exposed above the surface of the landfill. A butterfly valve is located on each of the wellheads so that adjustments can be made to the amount of vacuum applied to each well. A small stopcock valve is located on the wellhead so that small samples of gas can be collected for monitoring purposes. A six inch diameter flexible polyvinyl chloride (PVC) Kanaflex tubing is attached to the top of the six inch HDPE wellhead. A 45 degree elbow in the tubing directs it back towards the landfill where it connects to a six inch HDPE lateral pipe. This two to three foot section of flexible PVC tubing reduces stress on the HDPE pipes which may result from differential settling of the landfill.

Landfitl closure plans require a flexible membrane liner to be placed over the landfill. The purpose of the liner is to prevent rainwater from leaching through the landfill. The gas recovery project requires that holes be placed in the liner in order to maintain access to the wellheads. This creates openings in the liner which could allow the introduction of rainwater which would increase leachate volumes from the landfill (Davison, 6/20/91). To eliminate this potential problem, EPUD constructed collars around the wellheads. The collars are cone shaped and sealed around the wellhead so that rain water is diverted away from the holes in the membrane 1 iner.

Phase I of the landfill is no longer active and the finished grade resembles a large mound or hill. EPUD has located vertical wells in a circular pattern encompassing the peak of the hill (see App. C, Map $C$ ). Six inch diameter HDPE lateral pipes (mentioned above) connect the vertical wells to a main 10 inch diameter HDPE header pipe. The lateral pipes have a minimum slope of 4 percent from the well to the header pipe. The slope is necessary to prevent a buildup of condensate in the pipes. The 10 inch header pipe is placed in a circular pattern to collect gas which emanates from the wells through the lateral pipes.

Two low points are located along the 10 inch header pipe which encompasses phase I of the landfill. Condensate traps are 
located at each of these low points to remove condensate from the pipes before it reaches the plant. The condensate traps are drilled to a depth of 20 feet below the surface of the landfill. The traps consist of 10 inch diameter PVC piping that is centered in the well and backfilled using the same specifications that are used to backfill the vertical wells. The condensate drains into the traps and seeps back into the landfill through perforations in the bottom of the pipe. The 10 inch main header pipe carries the gas under ground to the plant. When the pipe crosses under the access road it passes through a culvert constructed of 18 inch diameter corrugated pipe. (Zelenka, 6/19/91)

Horizontal Wells: Three horizontal wells are in Phase II area of the landfill (see App. C, Map B). Although this portion of the landilil is referred to as phase II, it was the first area in the landfill to be filled. The current maximum depth of garbage in this portion of the landfill is 40 feet. EPUD excavated three parallel trenches in this existing garbage that are four feet wide and five feet deep. The $t$-nches are backfilled with three feet of gravel covered by 2 feet of clay (see Appendix A, Figure 2). An 8 inch diameter HDPE pipe is centered within the 3 foot layer of gravel (three-fourths to one and one half inch) backfill. The 8 inch HDPE horizontal well is perforated with eighteen $5 / 8$ inch diameter holes per foot. The south end of the well is capped. The north end of the well angles out of the trench so that the well head can be accessed above ground. The horizontal well heads include butterfly valves so that the amount of vacuum applied to the wells can br adjusted. The well head also includes a small stopcock valve so that samples can be collected for monitoring purposes.

The horizontal wellheads are located close to the access road so that they will not be covered by the additional 60 feet of garbage which are placed in this area of the landfill in phase II. The three horizontal wells tie into an eight inch HDPE header pipe which goes underground, through an 18 inch corrugated pipe under the access road, where it enters a water knock out tank at the plant. A condensate trap, as previously described for the vertical wells, is located on the 8 inch header pipe before the pipe crosses under the access road (Zelenka, 6/19/91). The approximate amount of piping used to construct the project is listed in the following table.

\begin{tabular}{|c|c|c|}
\hline PIFE 8 IZE AND TYPE & PIPE LENGTH & PIPE USE \\
\hline 6" diameter HDPE SDR 17 & 1217 feet & Vertical wells \\
\hline 8" diameter HDPE SDR II & 2725 feet & Horizontal Wells \\
\hline 6" diameter HDPE SIR 17 & 1400 feet & $\begin{array}{l}\text { Lateral Pipes and } \\
\text { Header pipes }\end{array}$ \\
\hline 8" diameter HDPE SDR 17 & 975 feet & \\
\hline $\begin{array}{l}10^{\circ} \text { diameter HDPE SDR } \\
17\end{array}$ & 2750 feet & \\
\hline
\end{tabular}




\begin{tabular}{|l|l|l|}
\hline 3" diameter HDPE SDR 11 & 2430 feet & $\begin{array}{l}\text { Condensate Drain } \\
\text { Pipe }\end{array}$ \\
\hline
\end{tabular}

Power Plant: The plant building is located on the north side of the access road just north of Phase II of the landfill (see App. $c$, Map $c)$. The 60 foot by 36 foot one story building is constructed on a crushed rock pad consisting of 18" of bar run sand or gravel and 6 inches of crushed gravel. The dimensions of the pad are 101 feet by 60 feet. The plant is staffed by one full time employee for eight hours a day.

The building is insulated with 3 inches of fiberglass padding in order to reduce some oi. the noise from the engines and to prevent moisture from building up inside the building. Exhaust noise from the engines is muffled by silencers located on the roof of the vilding.

At the power plant the header pipes emerge from the ground and lead into a water knock out tank. The water knock out tank further removes condensate from the gas. The condensate from the water knock out tank drains to a 3 inch diameter HDPE condensate drain pipe which leads away from the plant to the existing leachate lagoon ponds for the landfill. The gas exits the water knock out tank and passes through a $10 \mathrm{micron}$ coarse filter which is installed to remove particulates that are 10 microns or greater in size. The gas then passes through a 75 horsepower blower which is also located outside of the building. The blower creates a vacuum on the pipes and draws the gas out of the landfill through the wells. The gas is then piped into the building and enters a second gas prefilter system which removes particulates down to 0.1 microns in size. The gas then enters two 800 kilowatt, 16 cylinder, CAT 3516 internal combustion engines.

In addition to the generation of electricity, some components of the power plant (such as the blower) require a certain amount of electricity in order to operate. The demand for electricity required to operate the plant is referred to as the parasitic load. The parasitic load at this plant reaches approximately 125 kilowatts per engine.

Oil makeup tanks are located in a separate room of the building. Two 275 gallon oil makeup tanks are used to replace oil in the engines. Each engine contains 120 gallons of oil. One 10 gallon wall mounted oil reservoir is located next to each engine. 'I is s 10 gallon reservoir contains a site check so that oil levels in the engine can be monitored. Oil is replaced in the engines approximately every 25 days. A curb is around the oil storage tanks in order to contain the oil in case of a spill. A curb is also located beneath the pipe which carries oil to the engines. A gr dted pit is located between the two engines which will serve as a closed drain for any oil spilled in the area. 
A water cooling system is used to prevent the engines from overheating. This consists of a closed looped system of water and antifreeze which circulates through a radiator.

The engines operate generators which send electricity through conduits which are routed through the floor of the building to a step up transformer which is located on a pad outside of the building. The dimensions of the transformer pad are 10.5 feet by 6.5 feet. The transformer steps up the voltage on the lines from 4,160 volts to 20,800 volts. The transformer contains 640 gallons of oil which is permanently sealed within the transformer.

The main hazard at the plant is the potential for an explosion due to methane buildup. The power plant is equipped with a mechanical ventilation system, a methane sensor in the ceiling of the building, and fire extinguishers. These features help to reduce the hizard of explosion at the power plant. The community of Goshen which is located about 1.5 miles northwest of the site has a fire department which will be on call for the gas recovery project. In order to further protect equipment and increase safety, the CAT engines and the power plant building are equipped with sensors to monitor various parameters. The following parameters are monitored in the building to determine when a full. or partial shutdown of the piant is necessary: unacceptable levels of methane in the building, battery system failure, grourd fault, overcurrent, phase unbalance, building forced air ventilation failure, and gas blower failure. The following parameters are monitored in the individual engines to determine when the shutdown of an individual engine is necessary: oil level, jacket water level, oil pressure, oil temperature, cylinder exhaust temperature, stack exhaust temperature, jacket water temperature, inlet manifold temperature, overspeed, detonation, jacket water pressure, phase unbalance, current unbalance, generator bearing temperature, generator winding temperature, oil filter differential pressure, kilowatts, and reverse power. These sensors are wired to a computer which contains preset limits for each of the parameters. If a sensor detects a parameter which exceeds preset limits, the plant or an individual engine will automatically shutdown. (Zelenka, 6/19/91)

Electricity generated by the plant is carried over a new 3-phase $3 / 4-m i l e ~ 20.8 \mathrm{kV}$ wood single-pole transmission line. The 3-phase transmission line replaced and relocated a single-phase line which extended from the generator site at the landfill to the existing 2-mile long Short Mountain feeder. The generator output is normally fed into the EPUD creswell substation over the short Mountain feeder. However, during outages of that feeder, EPUD can switch off the feeder to Creswell and switch on the feeder to the EPUD Pleasant Hill substation. The new line runs along the north side of the access road. The first pole includes a pole mounted transformer. The pole mounted transformer is equipped with plastic cones for raptor protection. 
In addition to the site development and the installation of gas gathering wells, piping, pumps, water separators, and the generator itself, the only new construction is the 3/4-mile of $20.8 \mathrm{kV}$ transmission line between the generator and the line tap to the short Mountain feeder. The new line portion includes the appropriate positioning of phase wires to insure raptor protection and minimum levels of electromagnetic fields.

Decommissioning of the power plant includes dismantling the power plant facility and removing the transmission line. The gas collection system will remain buried in the landfill and the wellheads will probably be removed and sealed off. Whether or not the header pipes (pipes which lead to the power plant) are sealed will depend on Lane county's requirements for venting and recovering the gas once the power plant is closed.

\subsection{Other Actions}

Applicants for Billing credits develop each potentially qualifying action independently and submit them to Bonneville Power Administration separately. Therefore, collective consideration of all potential actions is not practical. However, implementing the proposed action will not foreclose future consideration of other potential BPA energy resource actions by means of the Billing credit Program and other resource acquisitions mechanisms. In fact, because this proposed action would merely reduce, not eliminate, the need for power, other resources, independent of the proposed action, will likely be considered, pursuant to NEPA, regardless of whether a Billing credit is granted for the proposed action. Resource types potentially available to meet future load growth include:

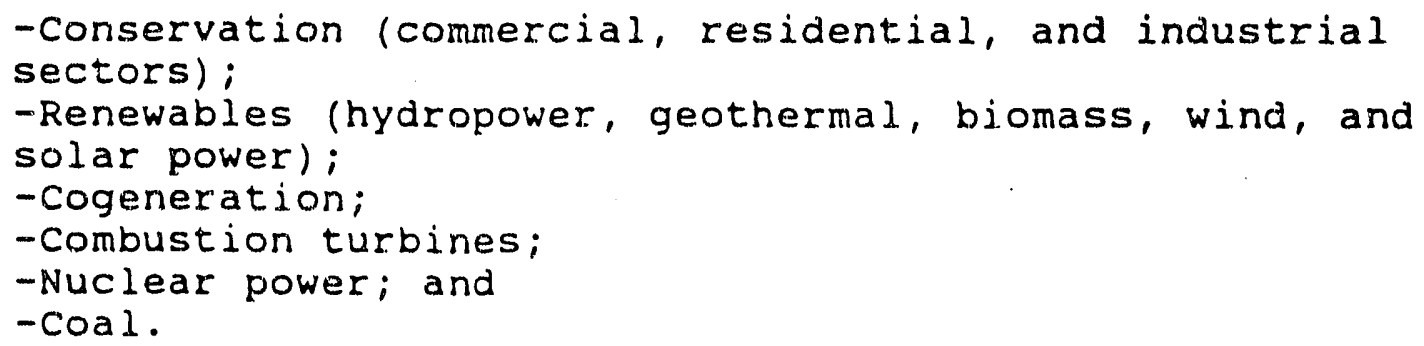

To comparatively evaluate these resource types, BPA is currently preparing an environmental. impact statement (EIS) on its resource programs (Resource Programs Draft EIS, April 1992).

Generally, every two years, BPA prepares a Resource Program that communicates how BPA proposes to meet its expected load obligations. For each Resource Program, alternatives are examined which are composed of different combinations of energy resource types from BPA's resource stack (the resource stack is the list of resources, ordered generally by cost, forecast to be available to meet electric power needs). BPA's planning model relies on this resource stack in simulating resource acquisitions and serves as a basis for BPA's resource planning decisions. 
In developing a Resource Program, BPA prepares load forecasts jointly with the Northwest Power Planning Council. A range of forecasts are prepared to reflect uncertainties about future load growth. Next, a range of load/resource balances are prepared by comparing the capability of the existing Federal system resources to the range of projected Federal system loads over the next 20 years. In a parallel process, BPA and the council develop new resource supply forecasts to plan acquisition of cost-effective resources as needed to meet load growth and to facilitate program design. pursuant to this formula, resources other than the proposed action will undoubtedly be examined and evaluated in the future for their eligibility and capability to satisfy BPA's future needs.

\subsection{ENVIRONMENTAL IMPACTS OF THE PROPOSED ACTION AND \\ ALTERNATIVES}

3.1 PROPOSED ACTION

3.1.1 Land Use

The gas recovery project is lccated in a rural agricultural area. one main access road leads to the project site from I-5. Public access to the short Mountiin Landfill and power plant site is restricted by a security attendant located in a building at the entrance to the site. The attendant is on duty from 8:00 in the morning until 6:00 at night. At 6:00 P.M. a gate, which blocks entry to the site, is closed and locked.

The major land use at the project site is the disposal of municipal solid waste. Landfill operations include a shed for landfill employees two leachate lagoon ponds located in the southwest portion of the property, and a metals separation area which is located jlist north of the landfill access road (see App. C. Map B).

Limited land uses other than the disposal of solid waste also occur at the site. A pistol range is located on the north side of the access road west of the proposed project (see App. C, Map B). This site is used as a practice site for the Eugene police Department. Use of the pistol range will not be affected by the proposed gas recovery project.

A model airplane runway is located east of the pistol range and south of the access road (see App. C, Map B). This runway is used on a regular basis by members of a model airplane club. The project sponsor (Zelenka, 6/18/91) usualiy sees two to three people using the site during the week and more on the weekends. Use of this runway is not expected to be affected by the gas recovery project. The short Mountain Landfill will eventually eliminate the model airplane runway as a result of filling during Phase IV of the landfill operations. This is part of the long term plan for the landfill and the model airplane club recognizes that it is only being allowed interim use. 
See section 4.5 for more information regarding local land use plans, and relevant zoning information.

Unavoidable Adverse Impacts. Short term increased traffic levels during decommissioning, and increased noise levels and air emissions from power plant operations would have minor adverse impacts on land lises. Impacts to the three land uses on site (municipal solid waste landfill, pistol range, and model airplane runway) are not significant for the following reasons:

traffic increases will be small and short term, 2) noise levels from the pxoject are similar to surrounding levels, and 3) air emissions axe regulated by a permit which limits the concentration of pilidutants in the area (pollutants shali not exceed Natioral Ambient Air Quality standards).

\section{1 .2 Vegetation}

There is a variety of vegetation surrounding the site. Short Mountain which borders the site to the north is upland and mostly forested with oak, fir, and pine species. The southern portion of the site near camas swale creek is wetter and contains vegetation common to wetlands. The landfill area has been mostly disturbed; grasses and weeds are beginning to reestablish themselves in the area.

Most features of the power plant project are constructed on sites that have previousiy been disturbed by landfill operations. The wells are drilled into inactive portions of the landfill and the generating plant is built on a site that was previously excavated as cover material for the landfill. The only exception to this is the aduition of an upgraded transmission line. A new transmission line is constructed just north of the access road ard runs parallel to the access road from the generating plant to just east of the pistol range, it then turns west to connect to the existing EPUD transmission line which runs north and south along the east side of I-5. construction of this transmission line had minor and localized impacts on grasses located on the north side of the access road. The impact consisted of approximately 10 auger holes which have been drilled for the installation of transmission line utility poles. The impact to vegetiation is minimal.

Vegetation control at the power plant site is necessary for saftey purposes. EFUD maintains several options for dealing with this problem. See section 4.15 .8 for more information

See section 4.2 for information regarding state and Federal threatened or endangered plant species.

Unavoidable Adverse Impacts. Approximately 10 auger holes have been drilled for the installation of new utility poles. This impart on vegetation was not significant due to the type and small size of the area affected. 


\section{1 .3 Water}

Operation of the gas recovery project should not change existing surface or ground water patterns. Camas swale creek runs east along the southern portion of the landfill site and into the coast Fork Willamette. The coast Fork Willamette River runs north just east of the short Mountain Landfill site. Leachate lagoon ponds have been constructed in the southwest cornei of the landfill site to brid leachate collected from the landfill. It has been estimated that approximately 280 gallons of leachate per day enters the leachate lagoon ponds (2elenka, 6/19/91). A surface water diversion ditch has been constructed around the landfill so that surface water runoff from short mountain will be diverted around the landfill before it drains into camas swale creek.

Condensate from the EPUD project is piped to a manhole that drains into the landfill's leachate lagoon punds. condensate volumes vary and are difficult to predict with existing information. Energy Tactics (the construction contractor) estimates that the total volume of leachate/condensate flowing into the lagoon ponds is similar to existing volumes of leachate from the landfill (zelenka, 6/91). However, it is possible that the condensate/leachate volumes generated by the londfill and the power plant marginally exceeds existing leachate volumes from the landfill.

Leachate in the lagoon ponds evaporates over time. However, leachate levels in the ponds increase with time and when the leachate levels reach a height of three feet below the top of the berms which surround the ponds, the leachate is spray irrigated over landfill areas identified as Phase $V$ and Phase VI on Map $B$ (Appendix $C$ ). Leachate from the ponds is usually spray irrigated in the summer and the ponds fill up over the winter. As landfill operations expand to the east, the present spray irrigation area will not be available for leachate disposal. Expansion of the landfill may also require larger leachate lagoon ponds for increased volumes of leachate. other methods for disposing of the leachate/condensate may be necessary as the landfill expands (Davison, 6/20/91).

Lane county has a permit for landfill operations from the Hazardous and Solid Waste Division of the oregon Department of Environmental Quality (DEQ). The landfill permit requires Lane county to take semiannual samples upstream and downstream in Camas swale creek, at the creek's confluence with the surface water diversion ditch, and at each groundwater monitoring well (DEQ has several groundwater monitoring wells on site). If the leachate/condensate is found to contain hazardous materials, the leachate/condensate will be disposed of at a site which is assigned for hazardous waste disposal. This may require loading the leachate/condensate into trucks and hauling it to an approved hazardous waste disposal site.

Some of the land bordering camas swale creek is identified as 
wetlands by the National Wetlands Inventory (see section 4.8). construction and operation of the gas recovery project is limited to Eill areas of the landfill and areas north of the landfill. operation of the gas recovery project is not expected to have an impact on wetlands which border camas swale creek.

Onavoidable Adverse Impacts. The project is not expected to affect any surface water or ground water systems.

3.1.4 Fish and wildife

Camas swale creek has been channelized and degraded by agricultural runoff. Cut-throat trout may spawn in upper areas of the creek and introduced warm water fish species such as brown bullhead may also be present. Large mouth bass are possible but not likely to be found in the creek. The creek has very low volumes, especially in the summer time (Wade, 6/91).

Rainbow trout and cut-throat trout are found in the coast Fork Willamette River at least seasonally and probably year round. There are a very 1 imited number of winter steelhead which migrate through this ar a. Backwaters and sloughs to the coast Fork willamette contain warm water fish species such as crappie, blue gill, large mouth bass, and bullhead. The gas recovery project is not expected to have any impact on local fisheries (wade, $6 / 91)$.

A great blue heron rookery is located approximately one mile east of the project site along the coast fork willamette River. The gas recovery project is located at a sufficient distance that it is not likely to have any impact on the roskery. Two osprey nests are located in the same area and somewhat closer to the landfild property. Osprey are fairly tolerant of development and noise and the project is not expected to have any impact on this species (Castillo, 6/14/91). Deer and migratory birds are also present in the area but are not expected to be affected by the project.

See section 4.2 for more information regarding Federally Threatened and Endangered Species.

Onavoidable Adverse Impacts. Increased noise levels and air emissions from power -ant operations may have minor adverse impacts on fish and widlife near the project site. These impacts are not significant for the following reasons: 1) the project is located at a sufficier distance from rivers (fish) and nesting sites (for osprey and blue herons) to minimize impacts, 2) air emissinns are required to meet National Ambient Air Quality standards, $\therefore$ changes in noise levels are small and increm ntal to the existing high levels present from the landfill operations, and 4) increased traffic levels from decommissioning will be short term and low volume. 


\section{1 .5 soils}

The main soil located beneath the landfill is identified in soil conservation Service, Soil survey Maps as Natroy silty clay loam. vegetation common to this type of soil is rushes, sedges, grasses, and scattered rose, hawthorn, and oregon ash. Permeability of this soil is very slow due to a high clay content. This soil is subject to severe shrinking and swelling.

The main soil type that is located on short Mountain and on portions of the access road is a shallow well drained soil. The vegetation is mainly scattered oregon white oak, Douglas-fir, poison-oak, and forbs and grasses. Other soils located in the access road area are also well drained. Vegetation common to these soils include Douglas-fir, oregon white oak, Pacific madrone, vine maple, wild rose, and grasses. A deep, poorly drained soil is located near I-5 surrounding the most eastern portion of the access road. Vegetation common to this type of soil includes grasses, sedges, western brackenfern, oregon ash, oregon white oak, and occasional Douglas-fir.

The main soil type in the camas swale creek area is a deep, poorly drained soil common to flood plains, terraces, and fans. Vegetation common to this soil type includes oregon ash, hawthorn, rushes, sedges, and grasses.

The existing soils were minimally affected by development of the project. Changes resulted primarily from relocation of very small amounts of existing soil due to the installation of utility poles along the north side of the access road. Some of the pipes transporting gas and condensate are buried underground, however, these pipes are buried in areas that have previously been disturbed by landfill operations.

Onavoidable Adverse Impacts. Approximately 10 auger holes have been drilled for the installation of new utility poles. This impact on soils is not significant due to the small size of the area affected.

\section{1 .6 Air Quadity}

Air quality in the area is monitored for ozone, by Lane Regional Air Pollution Authority (LRAPA) approximately six miles south (or downwind) of the project. To date, results from the monitoring have not exceeded National Ambient Air Quality standards (NAAQS) The Eugene-Springfield Urban Area has been designated as a PM10 (particulate matter which is 10 microns and smaller) nonattainment area, which exceeds the 24-hour PM10 NAAQS. This project is outside the Eugene-springfield Urban area, but close erough to potentially impact the area. EPUD is filtering the gas, down to 0.1 micron in size, before it enters the combustion engines. This project is not considered to be a significant source of PMIO (Arkell, 1/21/92). The project site is not located within (or close enough to potentially impact) any other EPA Classified Air Shed (Arkell, 6/27/91). 
An Air Contaminant Discharge Permit (ACDP) is required for this Project from LRAPA. Special rules for hazardous air pollutants, the Prevention of Significant Deterioration (PSD), or New Source Performance standards (NSPS) are included as part of an ACDP. An ACDP is required for this project because the project is a source that will emit more than 10 tons per year of any pollutant. Any source that has an ACDP must modify its permit before making equipment changes.

An ACDP permit was issued on April 1, 1990 and modified on July 5, 1991 (see Appendix B attachment).

The ACDP contains limits for oxides of Nitrogen (NOX), Carbon Monoxide (CO), and Volatile organic compounds (VOCs). These emission limits are provided in the permit for two stages of the project. Stage one, which is being considered for Billing credit, allows the simultaneous operation of two internal combustion units and stage Two increases that number to seven.

The site is not located within a nonattainment area for $c 0$, vocs or Nox. Modeling results indicate that Nox is approaching the standard near the site. However, trase modeling results are based on background levels from Portland. Although portland is more well ventilated than the Eugene-Springfield urban area, historic monitoring data from Eugene indicate Nox concentrations are probably well below the standard (Arkell, 1/21/92). The permit requires post completion monitoring for Nox to verify the modeling results. The permit also specifies that until the permittee can demonstrate, through monitoring, that NAAQs are not being exceeded and are not in jeopardy of being exceeded in proximity to the site, only two of the internal combustion units may be operated at any time. Ozone is another pollutant of concern near the project site and LRAPA stated its concern about nearing or exceeding the standards for ozone. Although the project is not a direct source of ozone, ozone can be created by a photochemical reaction between hydrocarbons and Nox. Therefore, if the NAAQS for ozone is exceeded, Nox reductions will most likely be a part of the attainment strategy to reduce ozone. A possible consequence to the plant would be a permit modification that includes a requirement for additional Nox controls.

If NAAQS are exceeded for Nox and thus ozone, a possible impact would be detrimental human health effects. ozone can irritate the human respiratory tract. Generally, young children and older people are most sensitive to ozone (Arkell, 6/91). Ozone has also been found to damage vegetation and reduce crop production (Heck, 6/91).

Quantitative air modeling has been conducted for this project. Nitrogen dioxide monitoring data from portland was used to provide a background concentration of $0.019 \mathrm{ppm}$ because ambient air quality data was not avai. ble for the project site. One-hour impact predictions were converted to annual averages. Results of 
the modeling indicate a maximum annual off-site impact of 53 micrograms per cubic meter. This concentration is eqlal to 0.028 ppm, which, when added to the $0.019 \mathrm{ppm}$ background equals 0.047 ppm. This is less than the NAAQS of $0.053 \mathrm{ppm}$. However, as inentioned above, monitoring is required in the ACDP to ensure NOX levels do not exceed NAAQS.

The following table illustrates emissions of concern that are expected from the new CAT 3516 engines, and the emission limits that are presentiy listed in the ACDP for the first stage of the project.

$\begin{array}{lllll}\text { Stage 1:: } & \frac{\text { Parameter }}{\text { Total }} & \frac{\text { One } 3516 \text { Enqine }}{37.5 \text { tons } / \mathrm{yr}} & \frac{\text { Two } 3516 \text { Enqines }}{75 \text { tons } / \mathrm{yr}} & \frac{\text { Emission Limits }}{81.7 \text { tons } / \mathrm{yr}} \\ \begin{array}{l}\text { Hydrocarbons } \\ \text { Carbon }\end{array} & 18.75 \mathrm{tons} / \mathrm{yr} & 37.5 \mathrm{tons} / \mathrm{yr} & 45.8 \mathrm{tons} / \mathrm{yr} \\ \begin{array}{l}\text { Monoxide } \\ \text { Oxides of } \\ \text { Nitrogen }\end{array} & 18.75 \mathrm{tons} / \mathrm{yr} & 37.5 \mathrm{tons} / \mathrm{yr} & 38.8 \mathrm{tons} / \mathrm{yr}\end{array}$

Engine emissions listed in the table were based on the utilization of 450,000 cubic feet of landfill gas per engine per day (or 900,000 cubic feet of landfill gas for stage 1) (Zelenka, 6/19/91). Emission limits were based on the utilization of $1,225,900$ cubic feet of landfill gas per day for stage 1.

In 1987, West Coast Analytical service, Inc. performed a gas analysis on samples from the landfill. No detectable traces of problem elements were found. Results of this test are attached to the Air Contaminant Discharge Permit Application. During a personal communication, the EPA operations office in Portland (Craig, 6/24/91) provided a preliminary review of existing data from the landfill and the gas recovery project. Based on previous experience with landfill gases and leachate, EPA (Craig, $6 / 24 / 91$ ) suggested testing the leachate for vocs using lower detection levels. EPA methods 524.2 and 8240 both have a $0.1 \mathrm{ppb}$ detection limit. Testing was also suggested for gas samples from the landfill (collected wilile simulating vacuum conditions of the gas recovery system) using EPA method TO-14 for the determination of VoCs in ambient air using canister sampling GC analysis with a detection limit of 0.01 nanograms per microliter. EPA's concern is based on previous experience with landfilis found to emit substances such as Vinyl Chloride, PCE, or TCE. Vinyl chloride is a known human carcinogen and the other two compounds have been found to cause cancer in animals.

other concerns with air quality impacts from the project include the possibility of air entrainment of asbestos. Because vacuum conditions exist at the wells, it is possible that asbestos could migrate into the wells. If this situation occurs, much of the asbestos will be filtered from the gas by the gas prefilter system at the power plant. These filters remove asbestos particles down to 0.1 microns in size. Asbestos particles which 
are 5 microns in size or greater are known to cause cancer in humans. Asbestos particles less than 5 microns in size are not regulated (Primack, 7/3/91).

Odor: Net odor was reduced at the site when operation of the gas recovery project began. Odors at landfills are generally strong due to the gases released from decomposition. The gas recovery project captures most of these gases in pipes and burn thern in internal combustion engines therefore reducing odor at the landfill site (Arkell, 6/27/91).

Unavoidable Adverse Impacts. Unavoidable adverse impacts result from project emissions of certain air pollutants. These impacts are not significant because emissions are required by permit to meet NAAQS. An additional unavoidable adverse impact could result from the possible air entrainment of asbestos. This impact is not significant because the gas is filtered for asbestos down to 0.1 microns in size where the health risk from asbestos is associated with particles that are 5 microns in size or greater. Also the migration of asbestos into the gas recovery wells is minimal because asbestos in the landfill is mostly wet and trapped by other garbage materials.

\subsubsection{Public Health and Safety}

Possible health and safety impacts from the project include impacts from air emissions, impacts from increased noise levels, hazards due to the potential for explosions on site, and exposure to asbestos which was previously disposed of in the landfill.

An Air Contaminant Discharge Permit (ACDP) would not have been issued to EPUD if the project is expected to emit pollutants exceeding NAAQS (see section 3.1 .6 regarding air emissions). Therefore, emissions from the project are not expected to have an impact on human health.

An insulated building houses the internal combustion engines therefore muffling some of the noise from the engines. Silencers are installed on the roof of the building to muffle exhaust noise from the engines. An additional source of noise generated by the project includes a 75 horsepower blower located on a concrete pad outside of the building. Existing noise levels at the site are somewhat $h i g h$ due to landfill operations, $I-5$, and a pistol range which is located on site. The closest "noise sensitive property" as defined in the oregon Administrative Rules for noise control is approximately one mile away. People likely to be affected by the roise include the model airplane runway users and employees which operate the landfill and the power plant. Energy Tactics, the cinstruction contractor, has estimated a noise level of approximately $70 \mathrm{dBA}$ at a distance of 200 feet from the plant.

In order to minimize hazards due to explosion potential at the power plant, the building is equipped with a mechanical ventilation system, a methane sensor in the ceiling of the 
building, and fire extinguishers. These features minimize the hazard of explosion at the power plant. The nearast fire department is approximately 1.5 milez away. The CAT engines and the power plant building are equipped with sensors to monitor various parameters (see page 11). These sensors are wired to a computer which contains preset limits for each of the parameters. If a sensor detects a parameter which exceeds preset limits, the plant or an individual engine will automatically shutdown.

Public access to the site is restricted by a security attendant on duty at the entrance to the site from 8:00 A.M. to 6:00 P.M. at which time the entrance gates are then closed and locked. This minimizes the risk of impact to public nealth and safety.

Unavoidable Adverse Impacts. 1) Noise levels in the area increased as a result of the project. The impact from noise levels is not significant because the closest "noise sensitive property" is approximately 1 mile away (noise attenuates over distance), and noise levels at the site are already high due to landfill operations. Also I-5 passes between the project and the closest "noise sensitive property". 2) Area levels of certain pollutants will increase as a result of the project. However, emissions of pollutants from the project are not significant because they are required by permit to meet NAAQs. 3) Explosions may occur during operation but are not likely. The hazard of explosion is not significant and is minimized by sensors on the engines which detect unusual levels of gases. 4) Operation of the project pose limited potential for exposure to asbestos. Exposure is very unlikely but will be further minimized to insure that impacts are not significant. If, during operation, asbestos are entrained, they will be filtered down to 0.1 microns limiting exposure to employees operating the plant (see section 3.1.6 for more information).

\subsection{8 visual}

The most visible portion of the gas recovery project is the building which houses the engines and the generator. The EPUD plant is located at the base of short Mountain, just north of the landfill access road, approximately one third mile east of I-5. The entire Lane county Landfill site is bordered on the north by Short Mountain, on the west by I-5, on the south by Camas Swale creek and on the east by private property which borders the coast Fork Willamette River. The closest resident to the plant is located approximately 1 mile to the west of the plant on the west side of $\mathrm{I}-5$.

Initially the plant is visible from portions of $I-5$. Eventually however, the grading of the landfill will probably block all offsite views of the power plant. Short Mountain blocks any view of the plant from the north and the landfill will eventually block the view of the plant from all other directions. The final elevation of the landfill is planned for 680 feet and the elevation of the top of the plant will be located at approximately 610 feet (see App. C, Map D). Before the landfill 
is complete, residences located west of the project would have to see across $I-5$ and then another one third mile to be able to see the plant which is only about 20 feet ligh. Therefore, the visual impact from the plant is expected to be minimal.

A new transmission line has been constructed from the plant to I-5. This is visible from the highway. However, it replaced an existing line which was already located on the site.

Air emissions may be visible from the engine exhaust stack. The visibility of these emissions is not significant because EPUD's Air Contaminant Discharge permit states that visible emissions shall not exceed more than lor opacity for more than three minutes in any hour.

Unavoidable Adverse Impacts. A power plant which is approximately $60^{\prime}$ by $36^{\prime}$ by $2^{\prime}$ high is built on the site. The visual impact of the plant is not significan= since the discance to the nearest resident is one mile and across I-5, and because views of the plant will eventually be blocked by the final grading of the landfill. A new distribution line, which runs from the power plant to an existing EPUD line which runs parallel to I-5, has been constructed. This impact is not significant because it replaced an existing line. Air emissions may be visible from the engine exhaust stack. The visibility of these emissions is not significant because EPUD's Air contaminarit Discharge permit states that visible emissions shall not exceed more than 10 of opacicy for more than three minutes in any hour.

\subsubsection{Historic/cultural}

The gas recovery project is not expected to have any impact on historic or archaeological resources. See section 4.4 regarding consultations with the oregon state Historic preservation officer.

Unavoidable Adverse Impacts. No unavoidable adverse impacts to historical or cultural resources are expected as a result of this project.

\subsection{ALTERNATIVE OF NO AC'TION}

The no action alternative is BPA not providing a Billing credit to EPUD for firm power generated by the short Mountain Landfill gas recovery power project. Environmental impacts from the no action alternative are the same as the impacts from the proposed action because EPUD built the project regardless of whether it received a Billing credit from BPA.

\subsection{OTHER ACTIONS}

See sections 2.3 and referenced materials.

$\because 0$ ENVIRONMENTAL CONSULTATION, REVIEW, AND PERMIT REQUIREMENTS 4. 1 NATIONAL ENVIRONMENTAL POLICY

This environmental assessment is prepared pursuant to regulations implementing the National Environmental Policy Act (42 USC 4321 
et seg.), which requires Federal agencies to assess the impacts that its actions may have on the environment. The Department of Energy (DOE) will use the information in this environmental assessment to determine whether the proposed action, to offer a billing credit to EPUD, would have a significant impact on the environment. If the impacts may significantly affect the quality of the human environment, then an Environmental Impact statement will be required. If the impacts are not significant, DOE will issue a Finding of No significant Impact.

\subsection{ENDANGERED AND THREATENED SPECIES AND CRITICAL HABITAT}

The Portland Field Station of the U.S. risi and Wildlife service (FWS) (Wong, 6/24/91) was consulted regarding Federally listed Threatened and Endangered species and Critical Habitat. The species list for the area surrounding the project includes one plant which is Federally listed as Endangered. The Endangered plant is known as Bradshaw's Lomatium (Lomatium Bradshawii) and is listed to be located in section 6 , Township 18 South, Range 3 West, and in section 20, Township 18 South, Range 2 West. This includes areas surrounding the project site. Bradshaw's Lomatium is a type of parsley that is associated with wet prairies or wetlands. Given the site conditions and the project specificutions, the FWS did not expect the project to have an impact on the plant (wong, $6 / 24 / 91$ ).

On February 6, 1992, a plant survey was conducted at the landfill site along the newly constructed condensate pipe (see Attachment D). No endangered plant species are impacted by the project.

\subsection{FISH AND WILDLIFE CONSERVATION}

Emissions from gas combustion at the power plant and noise crtated by the engines are two features of the gas recovery project with possible impacts on fish and wildife. To minimize the impact from noise, the CAT engines are housed in a metal building that is insulated with 3 inches of fiberglass padding. The insulation muffles some of the noise from the engines. Exhaust noise from the engines is muffled by silencers located on the roof of the building. To reduce the impact from air emissions the plant includes gas prefilters to filter particulates (down to 0.1 microns in size) out of the gas prior to combustion in the engines. Gas emissions such as NOx, $C O$, and vocs are not expected to exceed National Ambient Air Quality standards at the site and are therefore not expected to have any measurable impact on $\mathrm{fish}$ and wildife in the area.

\subsection{HERITAGE CONSERVATION}

The oregon state Historic Preservation officer (SHPO) was consulted regarding sites that are listed on the National Register of Historic Places, sites listed as National Historic Landmarks, and sites identified as archaeologically sensitive (Prior, 6/18/91). None of the sites on the National Register of Historic Places or National Historic Landmarks would be impacted by the gas recovery project. Four archaeologically sensitive 
sites are located approximately one mile from the project, however, the project will not affect these sites.

The SHPO was also consulted regarding the statewide Inventory of Historic sites and Buildings for Lane county, and the Lane county Cultural and Historic Landscape Resource survey, 1985. None of the sites on the statewide Inventory would be affected by the gas recovery project. one field identified in the lane county Cultural and Historic Landscape Resource Survey is located across $\mathrm{I}-5$ to the northwest of the site (approximately $1.5 \mathrm{miles}$ ) (see Appendix B, Attachment 2). Since this site is located ac: uss the Interstate and north of the landfill it is not expected to be affected by the proposed project.

The National Park Service (NPS), Pacific Northwest Region, was consulted regarding sites listed in the National Registry of Natural/National Landmarks (Atkins, 6/91). None of the sites on the list were located in Lane county. The NPS also checked lists which exist for potential natural/national landmark sites. Twenty seven potential sites exist in Lane county, however, none of these sites are affected by the EPUD project.

\section{5 state, AREANIDE, AND lOCAL PLAN AND PROGRAM CONSISTENCY}

The Lane County Planning Department (Howe, 6/20/91) was consulted regarding local land use plans. Officiai zoning maps were provided which include the Short Mountain Landfill site and all of the surrounding parcels. These maps are included as Maps EI through EA (Appendix C). The site itself (Parcel number 100) is zoned for PF (Public Facilities) a.ld the power plant project is consistent with permitted uses. Permitted uses in this zone include "utilities essential to the physical, economic and social welfare of an area such as: (i) electric utility: electric transmission right-of-way, electric generation plant, electricity regulating substations. (ii) Gas utility: gas pipeline right-ofway, natural or manufactured gas storage and distribution points, gas pressure control stations... (v) solid waste disposal: refuse incineration, central garbage grinding stations, compositing plants, sanitary landfills and refuse disposal." A copy of the zoning information for Public Facilities is included as Attachment 3 (Appendix B).

Parcels directly surrounding the Short Mountain Landfill site are all zoned exclusive farm use or forest. A Greenway Boundary is located within the landfill site along the coast Fork willamette River. Approximately 85 acres of the Lane county parcel is located within the Greenway Boundary. Development or a change in land use within the Greenway Boundary requires a जreenway Development Permit (Howe, 6/20/91). EPUD's project does not include plans to develop or change the land that is located within the Greenway Boundary. The Greenway Boundary is delineated on the zoning maps which are included as Maps El through E4.

When an air, water or waste permit is required from the DEQ, a 
Land Use Compatibility statement is also required. This is DEQ's way of ensuring that the project is consistent with local land use plans (Amidon, 6/25/91). For this project an air permit was obtained through the LRAPA. LRAPA does not require a Land Use compatibility statement. However, if a water permit is required from DEQ for this project, then a Land Use compatibility statement will also be required by $D E Q$.

\subsection{COASTAL ZONE MANAGEMENT CONSISTENCY}

Consultation with the oregon Land Conservation and Development Commission (Ocean Resources) (Houte, 6/26/91) confirmed that the project site is located outside of the coastal zone.

\subsection{FLOODPLAIN MANAGEMENT}

The U.S. Army Corps of Engineers (Corps) (MCGowen, 6/14/91) provided a Flood Insurance Rate Map for the project site (included as Map $F$, Appendix C). Zone $A 3$ on the map represents the 100 year flood plain. Zone $B$ which covers a larger portion of the short Mountain Landfill site represents the 500 year flood plain. Zone $C$ which is also delineated on the map represents a zone which has minimal flooding or flooding which occurs less than every 500 years. The 100 year flood plain at the short Mountain Landfill site is located along the southern portion of the property along Camas Swale creek at an elevation of 507 feet. The 100 year flood plain elevation of the coast Fork willamette just southeast of the landfill is at an elevation of 507 feet. The gas recovery project is not located within the 100 year flood plain as identified on the Flood Insurance Rate Map.

\subsection{WETLANDS PROTECTION}

The area bordering Camas swale creek (the south end of the landfill) is identified in the National Wetlands Inventory as a wetland. This wetland area is a buffer zone between the landfill and camas swale creek. The gas recovery project does not include any construction south of the existing manhole above the leachtate pond.

on February 6, 1992, a wetland delineation was conducted at the landfill site along the newly constructed condensate pipeline. soils, hydrology, and vegetation were investigated consistent with the 1989 Federal Wetland Delineation Manual, which is accepted by the Department of State Lands (DSL), and the 1987 Wetlands Manual, which is adopted by the corps. The condensate pipeline does not cross wetlands regulated by DSL or the corps (See Attachment D).

Therefore, the gas recovery project does not have an impact on wetlands.

\subsection{FARMLANDS PROTECTION}

According to the Agricultural stabilization and conservation Service (Reerslev, 7/24/91), the closest farmlands to the site 
are located approximately one quarter-mile due south of the Lane county property boundary (on the south side of Camas swale Creek). Emissions from the plant are not expected to have a direct affect on local farmlands, however, farmland vegetation is often sensitive to ozone levels (Heck, 6/91). Emissions from the plant will include Nox and vocs which can combine to produce increased ozone levels. These ozone levels are expected to remain within National Ambient Air Quality standards and any indirect impact from the power plant is expected to be minimal.

\subsection{RECREATION RESOURCES}

Recreational resources at the site include a model airplane runway. As mentioned above (Section 3.1.1), the model airplane runway is located east of the pistol range and south of the access road. This runway is presently used on a regular basis by members of a model airplane club. Use of this runway is not expected to be affected by the gas recovery project. The short Mountain Landfill will eventually eliminate the model airplane runway as a result of filling during phase IV of landfill operations. The model airplane club recognizes that they are only being allowed interim use of the site.

The Coast Fork willamette River may include recreational resources such as fishing and boating. These uses are not expected to be affected by the gas recovery project. The project will not affect any National and wild seenic Rivers or National Wilderness areas (Wold, 6/17/91).

\section{- 11 gLOBAL maRMING}

rhis project will reduce the total "green house effect" by removing methane which would otherwise be released from the landfill. The gas from the landfill has been tested and the content was determined to be approximately 55 percent methane, 36 percent carbon dioxide, and 6 percent nitrogen. The estimated amounts of greenhouse gases removed and released as a result of the gas recovery project are listed in the following table. These numbers are based on the rated combustion potential of 450,000 cubic feet of gas per engine per day at 85 percent efficiency (Zelenka, 6/19/91). Oxides of nitrogen, which may contribute to global warming, should be released by the project. The project will prevent the release of approximately 9,589 tons of greenhouse gas (methane and carbon dioxide) while releasing approximately 15,638 tons (carbon dioxide and nitrogen). Although the weight of the emitted greenhouse gases will increase as a result of the project, methane is a more potent greenhouse gas than oxides of nitrogen and carbon dioxide. Therefore, the net effect of the project is expected to reduce the greenhouse effect (Arkell, 6/27/91). 


\begin{tabular}{|l|l|l|}
\hline GAS & $\begin{array}{l}\text { ESTIMATED VOLUME } \\
\text { REMOVED PER YEAR } \\
\text { 2 Engines }\end{array}$ & $\begin{array}{l}\text { ESTIMATED TONS } \\
\text { REMOVED PER YEAR }\end{array}$ \\
\hline Methane & $\begin{array}{l}153,570,000 \text { cubic } \\
\text { feet }\end{array}$ & 3,425 \\
\hline Carbon Dioxide & $\begin{array}{l}100,520,000 \text { cubic } \\
\text { feet }\end{array}$ & 6,164 \\
\hline GAS & $\begin{array}{l}\text { ESTIMATED VOLUME } \\
\text { RELEASED PER YEAR }\end{array}$ & $\begin{array}{l}\text { ESTIMATED TONS } \\
\text { RELEASED PER YEAR }\end{array}$ \\
\hline Carbon Dioxide & $\begin{array}{l}254,190,000 \text { cubic } \\
\text { feet }\end{array}$ & 15,590 \\
\hline Oxides of Nitrogen & 585,000 cubic feet & 38 \\
\hline $\begin{array}{l}\text { Numbers in the table were calculated assuming standard } \\
\text { temperature and pressure. }\end{array}$
\end{tabular}

4.12 PERMITS FOR STRUCTURES IN NAVIGABLE WATERS

EPUD's gas recovery project does not involve work or structures over or in any navigable waters of the united states and therefore does not require a section 10 permit (Marg, 6/91.).

\subsection{PERMITS FOR DISCHARGES INTO WATERS OF THE UNITED STATES}

EPUD's gas recovery project does not include filling in waters of the United States or involve any other activities regulated under Section 404 (Marg, 6/91).

Under the clean water Act, the DEQ has authority to issue permits, for certain discharges into waters of the United States. Discharges associated from this project (which consist of condensate from the gas recovery pipes) drain into the landfill's existing leachate lagoon ponds which are not waters of the United states. The DEQ believes that Lane county may need a water permit for the disposal of wastewater from their leachate lagoon ponds. EPUD, however, would not need a separate permit because its condensate should be authorized in the Lane county landfill permit (Ashbaker, 6/26/91).

\subsection{PERMITS FOR RIGHTS-OF-WAY ON PUBLIC IAND}

Permits for right-of-ways on public land are required when development or construction is proposed on public land. All of the construction or development for EPUD's gas recovery project occurred on Lane county property. Lane county's property includes two easements which border the east side of I-5. An EPUD easement (right-of-way) exists which runs north and south on the east side of I-5 and a Pacific Power and Light easement (right-of-way) runs north and south along the east side of EPUD's right-of-way. The electric transmission line is constructed from the power plant west across the Pacific Power and Light easement to the existing EPUD right-of-way. The transmission line that presently exists for the landfill also crosses PP\&L's right-of.. way.

EPUD and it's contractors are authorized to use the landfill 
through a landfill gas recovery agreement (see Appendix B, Attachment 4).

\subsection{POLLUTION CONTROL}

4.15.2 Prevention, control, and Abatenent of Environmental Pollution

The project includes gas prefilters to remove particulates from the gas. The gas will pass through two filters before it enters the engines. One of the filters removes particulates down to 10 microns in size and the second fiter removes particulates down to $0.1 \mathrm{microns}$ in size. The disposable portion of the 0.1 micron filter will need to be replaced approximately once every six months. The disposable portion of the 10 micron filter will need to be replaced approximately once every twelve months. Disposal methods need to be evaluated on a site specific basis. EPUD will have to analyze materials in tire filter to determine whether or not the filters will have to be disposed of in a hazardous waste landfill. With existing information it is difficult to predict the quantity and nature of particulates that will be removed by the filters.

California has the nation's strictest emission standards for stationary internal combustion engines. The CAT 3516 engines were designed to meet these California emissions standards. The California emissions standards limit emissions from the engines to 2 grams per horsepower hour for NOx, CO, and VOCs. Emissions from the gas recovery project should meet this standard and are not expected to exceed NAAQS.

4.15.2 Compliance with the clean Air Act

LRAPA's issuance of an Air contaminant Discharge Permit (ACDP) ensures compliance with the clean Air Act. A copy of the final ACDP is included in Appendix $B$ as Attachment 1.

4.15.3 Compliance with the clean water Act

The DEQ, Water Quality Division, stated that if the condensate from the power project is discharged to the leachate lagoons which are covered under Lane county's landfill permit, then EPUD will not need an additional permit to be in compliance with the clean water Act.

4.154 Solid and Hazardous waste

Solid waste generated as a result of the gas recovery project includes auger material from wells arilled during construction, particulate matter filtered from the gas, waste oil from the engines and condensate from the wells.

If the condensate/leachate is determined to contain hazardous materials, then disposal must avoid the leachate lagoon ponds. Should this occur, the leachate/condensate will likely be drained to a tank which will periodically be unloaded to vehicles that will transport the waste to a si: that is approved for hazardous waste disposal. If the disposable portions of the gas filters are determined to contain hazardous materials, then they must 
also be disposed of at a site that is approved for hazardous waste disposal. The closest approved site is located in Arlington, Oregon which is northeast of the project site approximately 300 miles away. This is the only site in oregon that is approved for the disposal of hazardous waste.

\subsubsection{Resource Conservation and Recovery Act}

The Resource Conservation and Recovery Act (RCRA) of 1976, authorizes EPA to establish regulations and progrims to ensure safe waste treatment and disposal. Three main programs were developed under RCRA. The first program, subtitle D, encourages States to develop comprehensive plans for the management of solid wastes (primarily non-hazardous). New subtitle D regulations are expected to be published in the near future. Until then, the DEQ, Hazardous and Solid waste Division, implements a state program for the management of solid wastes. Lane county has a Solid waste Disposal Permit from DEQ to operate the short Mountain Landfill.

The second program under RCRA, subtitle $C$, establishes a system for tracking hazardous wastes from "cradle to grave". The third program, subtitle I, regulates certain underground storage tanks.

At this time, EPUD's gas recovery project does not require a permit under RCRA. If, however, the condensate or the disposable portions of the gas filters are determined to contain hazardous substances, RCRA compliance issues may apply. Another RCRA concern relates to final closure plans (as required by $D E Q$ ) at the landfill. Landfill closure requires that a flexible membrane liner be placed over the landfill. The purpose of the liner is to prevent rainwater from leaching through the landfill. The gas recovery project requires that holes be placed in the liner in order to maintain access to the wellheads. This creates openings in the liner which could allow the introduction of rainwater which would increase leachate volumes from the landfill. To eliminate this potential problem, EPUD has constructed collars around the wellheads. The collars are cone shaped and sealed around the wellhead so that rain water will be diverted away from the holes in the membrane liner.

4.15.6 Noise Control Act

A noise permit is not required for the gas recovery project, however, according to Oregon Administrative Rules, new sources locating on sites used for industrial or commercial purposes in the last 20 years ("previously used") must limit noise to specified levels during various times of the day. The allowable statistical noise levels in any one hour are as follows:

$\frac{7 a \cdot m \cdot-10 \text { p.m. }}{L_{50}-55 d B A}$
$L_{10}-60 d B A$
$L_{1}-75 d B A$

$$
\begin{aligned}
& \mathrm{L}_{50}-\frac{10 \mathrm{p} \cdot \mathrm{m} \cdot \mathrm{d} \cdot \mathrm{dBA}}{\mathrm{a} \cdot \mathrm{m} .} \\
& \mathrm{L}_{10}-55 \mathrm{dBA} \\
& \mathrm{L}_{1}-60 \mathrm{dBA}
\end{aligned}
$$


$L_{1}$ is the noise level allowed for 1 of an hour, or 36 seconds. $\mathrm{L}_{10}$ is the noise level that is allowed for 108 of an hour, or 6 minutes, and $L_{50}$ is the noise level that is allowed for $50 \%$ of an hour, or 30 minutes. $75 \mathrm{dBA}$ is a noise level that would be comparable to what you would hear if you were standing next to I5 during heavy traffic. $90 \mathrm{dBA}$ is the noise level of a typical lawn mower. An air conditioner generates a noise level of about $50 \mathrm{dBA}$ for a person sitting next to it. Noise levels during the day in urban residential areas are approximately $50 \mathrm{dBA}$, while noise levels during the day in quiet residential areas are approximately 40 dBA.

Additional standards are listed in the oregon Administrative Rules regarding tonal type noises (whistling, roaring, humming, etc.). These types of noises are required to meet Octave Band Standards which are stricter than the noise source standards tabulated above.

If the project generates complaints against EPUD regarding excessive noise levels from the project, monitoring might be required to determine exact noise levels. When monitoring for regulatory purposes, noise levels are measured at the closest "noise sensitive property". "Noise sensitive property" is defined in the oregon Administrative Rules as "real property normally used for sleeping, or normally used as schools, churches, hospitals or pubiic libraries. property used in industrial or agricultural activities is not noise sensitive property unless it meets the above criteria in more than an incidental manner".

See section 3.1 .7 for more information.

1.15.7 Safe Drinking Water Act

The Safe Drinking water Act is implemented in oregon by the $D E Q$, Health Division (Putnam, 6/91). This act applies to public drinking water systems. A public drinking water system is defined as a system which has four or more water hookups, is a system which is used for drinking by employees or the general public at least 60 days out of the year. If a facility is defined by the state to be a public drinking water system, then the facility must comply with the safe Drinking water Act. Tre Act places limits on the amount of contaminants allowed drinking water. since EPUD's project will not constitute a public drinking water system, the project does not involve compliance issues with the safe Drinking water Act. Drinking water at the site consists of bottled water for the one full time person that operates the plant.

\subsubsection{Pesticides}

The National Electric Safety Code requires a weed free environment at electric facilities in order to minimize fire and safety hazards. EPUD is presently considering several options to maintain a weed free environment. EPUD placed a geotextile 
membrane liner 6 inches beneath the gravel pad which supports the generation plant. This prevents most weeds from growing around the plant. If weeds do appear in the gravel above the liner they are easily removed because they are not rooted in soil. Herbicides known as Roundup and oust may be used for spot application purposes. EPUD is also considering the option of hiring a contractor to apply herbicides at the power plant site.

\subsubsection{Toxic substances control Act (TSCA)}

The Toxic Substances Control Act of 1976, includes requirements and authorities for identifying and controlling toxic chemical hazards to human health and the environment. Under TSCA, EPA has authority to limit the manufacture, import, processing, distribution in commerce, use or disposal of a chemical when these activities are found to pose an unreasonable risk of injury to human health or the environment. TSCA also regulates specific activities involving the manufacturing, processing or distribution in commerce of polychlorinated biphenyls (PCBs). EPA Region 10 feels that the EPUD project will not involve TSCA compliance issues, however, they suggested that a more definitive answer could be obtained from Mark Greenwood, Director, office of Toxic substances, EPA, Washington D.C. (Colt, 7/1/91).

4.15.10 Federal Insecticide, Fungicide, and Rodenticide Act In oregon, the Federal Insecticide, Fungicide, and Rodenticide Act (FIFRA) is implemented by the oregon Department of Agriculture. The Act encompasses all uses of restricted pesticides including product registration, licensing and certification, and misuse investigations. All applicators of restricted pesticides must be licensed and certified by the state. Pesticides are defined under the Act as including any substance or mixture of substances intended for preventing, destroying, repeliing, or mitigating any pest, and any substance or mixture of substances intended for use as a plant regulator, defoliant, or desiccant (Mitchell, 7/2/91). Under FIFRA there are two types of pesticides: general use pesticides, and restricted pesticides. FIFRA does not require applicator licensing and certification for the application of general use pesticides (Parkins, $7 / 2 / 91$ ). See section 4.15 .8 regarding the possible application of general use pesticides (Roundup and oust) at the proposed project.

\subsubsection{Asbestos}

Asbestos has been deposited at various locations throughout the Short Mountain Landfill. Asbestos has been deposited in the cells shown as Phase 1 and Phase II (see App. C, Map B). In the landfill area identified as Phase $I$, the approximate locations of known asbestos deposits were identified and outlined by Lane county's Short Mountain Landfill personnel by placing panels on the landfill surface around deposits for aerial photography and preparation of a topographic map. In the area of the landfill labeled as Phase II, the location of asbestos deposits are not 
known. The contractor must therefore comply with all applicable federal, state, and local laws and regulations pertaining to the handling of asbestos. Asbestos is a known carcinogenic substance.

EPA Region 10, and the LRAPA both believe that the greatest concern with asbestos is as an air pollutant (Johnston, 6/20/91). Asbestos trapped within a landfill or in water does not have a tendency to migrate.

\subsubsection{Comprehensive Environmental Response, Compensation and} Liability ACt (CERCLA)

The Comprehensive Environmental Response, Con ${ }_{i}$ sensation and Liability Act of 1980 (CERCLA or Superfund), establishes programs and funds to deal with the release of hazardous substances in spilis and from inactive and abandoned disposal sites. The EPUD project is not expected to involve CERCLA compliance issues.

\subsubsection{Radon}

Naturally occurring radon levels at he EPUD project site are not known. ERA believes that it is cheaper to construct a building which includes radon abatement measures than it is to characterize radon levels at the site. EPA believes that some of the construction details of the EPUD power plant may serve as radon abatement measures (Leitch, 7/2/91). EPUD ventilates the building, and the building is located on a pad which consists of 2 feet of crushed gravel. A liner to prevent weed growth is placed beneath the gravel as well. It will be important to ensure that the ventilation system does not create a negative pressure in the building, therefore drawing air up through the ground beneath the building.

\subsection{PERSONS AND AGENCIES CONSULTED}

\section{Project Developers}

Alan Zelenka, Emerald Peoples Utility District, Eugene, OR

Mr. Richard Voldstad, Energy Tactics, Yaphank, NY

\section{Interest Groups}

Mr. Jerry O'Rourke, Creswell, Oregon

Lane County (Local)

County Planning

Solid Waste Management

Regional Air Pollution Authority

Tax Assessors

Environmental Health

Public Works

Clackamas County 
Solid Waste

state of oregon

Department of Environmental Quality

Historic Preservation office

Department of Agriculture

Public Utility Commission

Land Conservation and Development Commission

Health Division

Department of Fish and Wildlife

Agricultural Stabilization and Conservation service

Department of Insurance and Finance

\section{United States}

Fish and wildife Service

U.S. Environmental Protection Agency, Region X

U.S. Army Corps of Engineers

Bureau of Land Management, Eugene District

Bureau of Indian Affairs

U.S. Geological Survey

Warm Springs Agency

U.S. Environmental Protection Agency operations office

National Marine Fisheries Service

U.S. Department of Agriculture

National Park Service, Pacific Northeast Region

Soil Conservation Service

U.S. Environmental Protection Agency, Air, Toxics Division

U.S. Environmental Protection Agency, Office of Toxic Substances, Asbestos Section

\subsection{REFERENCES}

Lane County, Department of Environmental Management, Solid Waste Division. January 1976. Environmental Assessment, Short Mountain Landili, Lane County, Oregon. PTL-06.111.

Miles, T.R., L.S. Craig, and W.T> Greene, prepared for Oregon Department of Energy, Pacific Northwest and Alaska Bioenergy Program. October 1984. Guide to Oregon's Environmental Permits for Biomass Energy projects. ODOE Contract No. C50065.

United States Department of Agriculture, Soil Conservation Service. 1981. Soil Survey of Lane county Area, oregon.

United States Environmental Protection Agency, offices fo solid waste. January 1989. RCRA Orientation Manual.

United States Environmental Protection Agency, Office of Toxic 
Substances. June 1987. The Layman's Guide to the Toxic Substances Control Act. EPA 560/1-87-011. 
APPENDIX A 


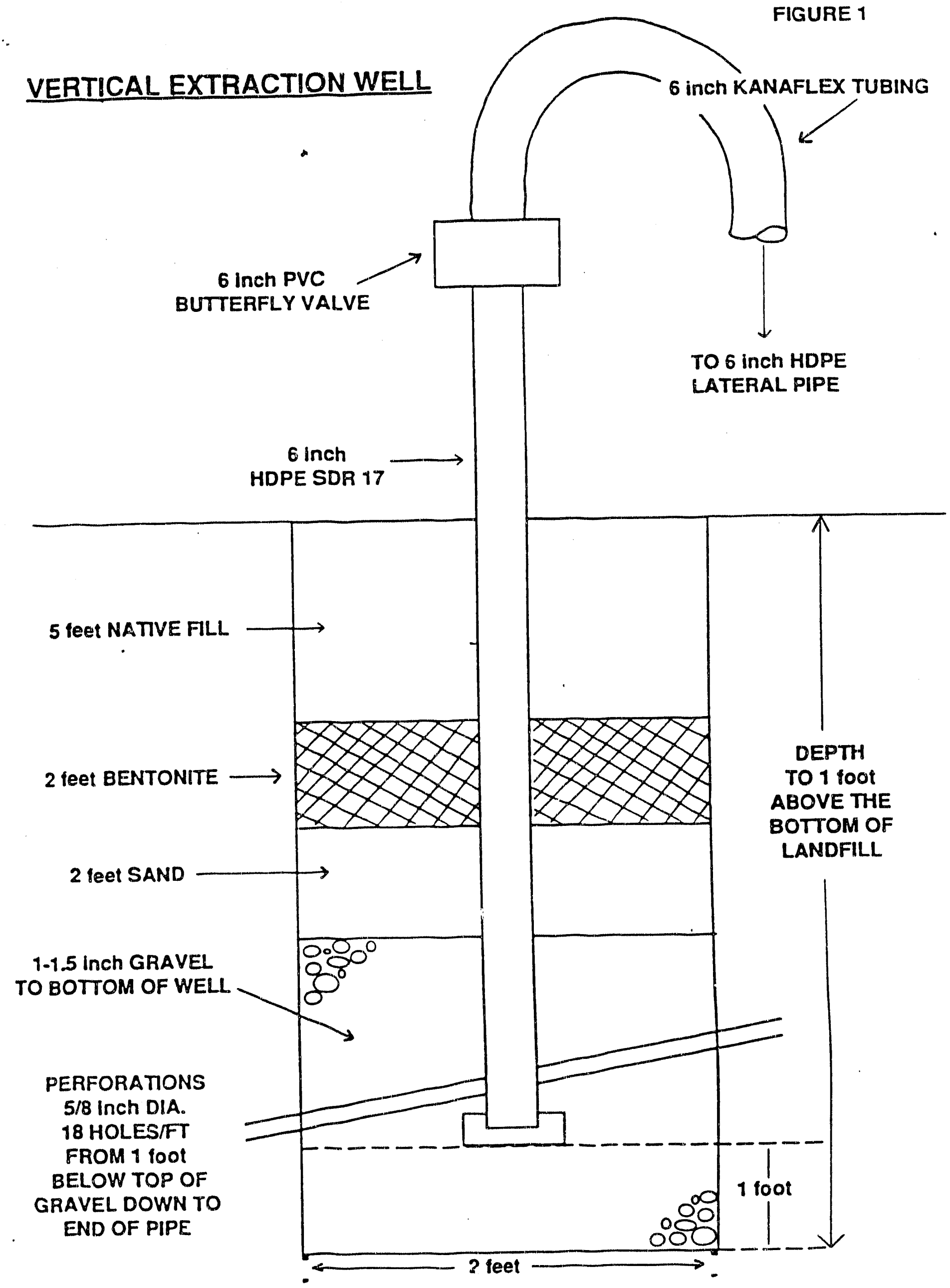




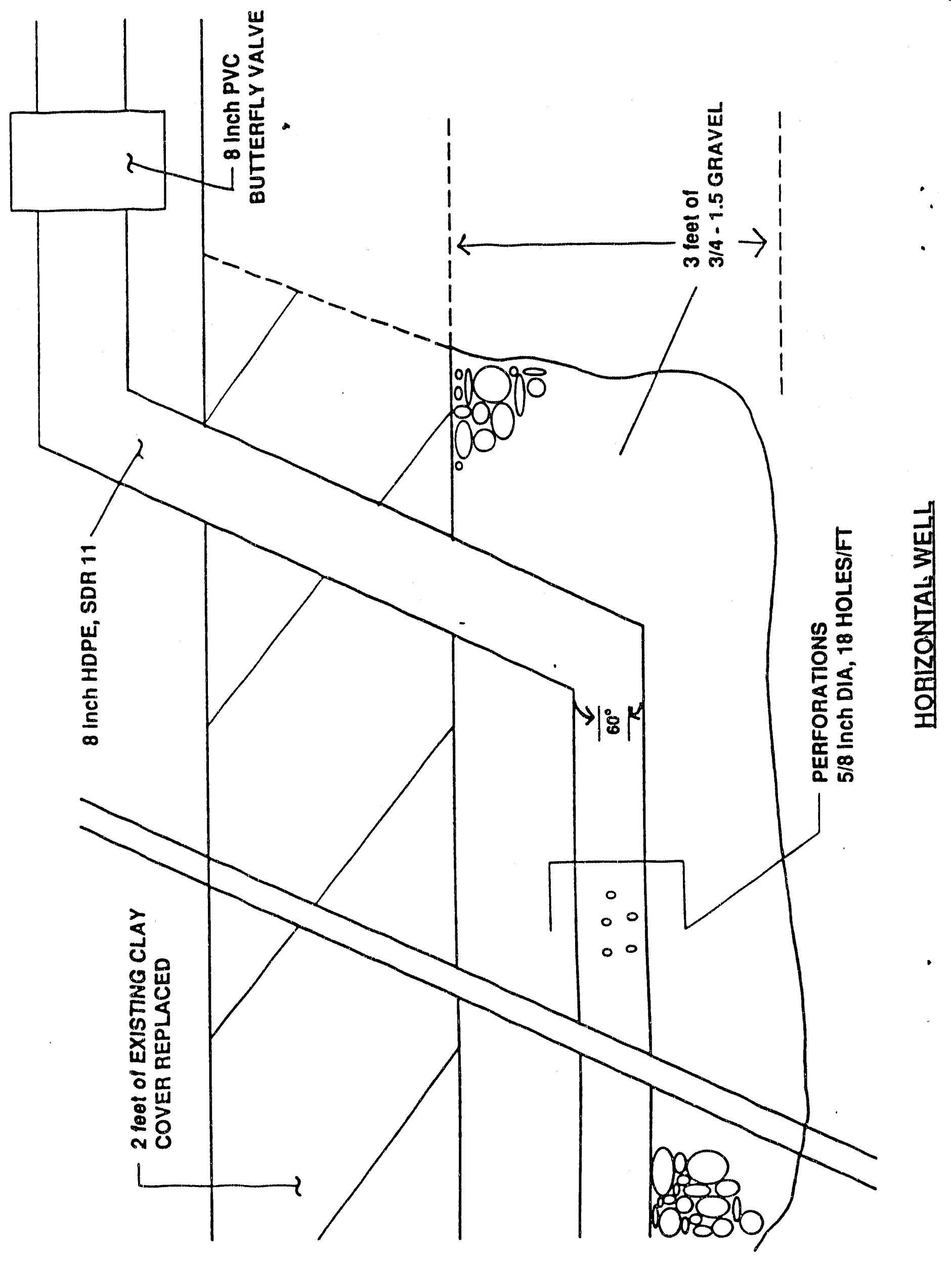


APPENDIX B 


\section{AIR CONTAMINANT DISCHARGE PERMIT}

Issued in accordance with provisions of Lane Regional Afr. Ponlution Authority Rules, Ttile 34

\section{EMERALD PEOPLES UTIUTY DISTRICT}

Short Mountain Landfil Project

Creswell, Oregon

Mailing Address:

33733 Seavey Loop Road

Eugene, OR 97405

Permit Number. 202536

Permit Type:

Issued:

Expires:

Modified:
PSD-Regular

April 1, 1990

March 31, 2000

July 15, 1991
Permitted Solurces:

Landfill Gas-fired Electrical

Power Generation 4911-55c

Other Sources on Permit:

Standby Gas Flare

Specific Emission Points:

Phase 1: 2 Industrial Internal

Combustion Engines

Phase 2: 5 Additional Industrial

(7 Total) Internal

Combustion Engines

By:

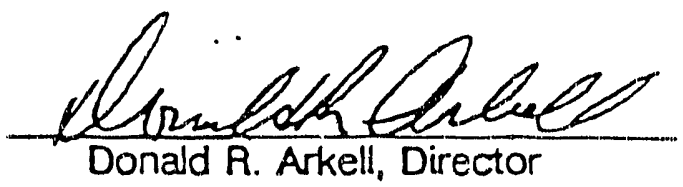

Date:

July 15, 1991 


\section{Permitted Activities}

Until this permit expires or is revoked, the permittee may discharge air contaminants from its operation in accordance with the requirements, limitations, and conditions bf this permit This specific listing of requirements, limitations, and conditions does not relieve the permittee from complying will all other rules of the Lane Regional Air Pcillution Authority.

\section{Specific Operational Conditions Imposed}

Until the permittee can demonstrate through participation with Lane Regional Air Pollution Authority in an ambient $\mathrm{NO}_{x}$ sturfy that national ambient air quality standards are nof being exceeded and are not in jeopardy of being exceeded in proximity to the site, only three of the internal combustion units may be operated at any time.

This permit may be modified, based on analysis of the ambient air monitoring data, to continue to limit the number of internal combustion units in operation at any time or to modify the PSEL restrictions.

\section{Performance Standards and Emission Limits}

1. Phase, 1 Ptant Site Emission Limits (PSEl) at 100\% Availability

- Phase 1.limits operation of the facility to not more than two (2) intemal combustion units at any time.

Total emissions from all sources located on the plant site shall not exceed the following levels:
Oxdes of Nitrogen $\left(\mathrm{NO}_{x}\right)$
$8.9 \mathrm{lbs} /$ hour
38.8 tons $/ y$ r
Carbon Monoxide (CO)
$10.5 \mathrm{lbs} /$ hour
45.8 tons $/ y r$
Volatile Organic Carbons
$18.7 \mathrm{lbs} /$ hour
81.7 tons/yr

These values are based on operating two (2) IC units 8,760 hours per year and utilizing 1,225,900 cubic feet of land fill gas per day. 
2. Phase 2 Plant Site Emission Limits (PSE)

Phase 2 limits operation of the facility to not more than seven (7) intemal combustion units at any time.

Total emissions from all sources located on the plant site shall not exceed the following levels:

$\begin{array}{lll}\text { Oxides of Nitrogen }\left(\mathrm{NO}_{x}\right) & 31.0 \mathrm{lbs} / \text { hour } & 135.8 \mathrm{tons} / \mathrm{yr} \\ \text { Carbon Monoxdde (CO) } & 36.6 \mathrm{lbs} / \text { hour } & 160.5 \mathrm{tons} / \mathrm{yr} \\ \text { Volatile Organic Carbons } & 65.3 \mathrm{lbs} / \text { hour } & 285.9 \mathrm{tons} / \mathrm{yr}\end{array}$

These values are based on operating seven (7) IC units 8,760 hours per year and utilizing 2,410,200 cubic feet of land fil gas per day.

3. Visible emissions from any engine exhaust stack shall not exceed more than 10 ị percent opacity for more than three minutes in any hour.

\section{Other Conditions}

1. Lane Regional Air Pollution Authority representatives shall be permitted access to the

- plant site at all reasonable times for the purpose of making inspections, surveys, collecting samples, obtaining data, and otherwise conducting necessary fuhctions related to this permit.

2 All plant processes discharging air contaminants and all air contaminant collection and disposal facilities shall be operated and maintained at all times in a manner which shall minimize air comtaminamt discharges.

3. No open buming shall be conducted an the plant site.

4. No person shall cause or perrnit particulate matter to be handled, transported, or stored without taking necessary precautions to prevent it from becoming a public nuisance. 
5. No person shall cause or permil particulate matter from becoming airborne frorn open areas located within a private lot or privata roadway, if such release bebomes a public nuisance.

6. Without first notifying the Authortity in writing and obtaining approval, no person shall construct, install, or establish a new air contaminant source, or modity an existing source. If modification or enlargement of an existing air contaminant source results in an incre se in strength or volume of air comtaminants, a permit modification is also required.

\section{Monitoring and Reporting}

1. Upset conditions or breakdown of equipment or air pollution control equipment which mray result in exceeding the emission timitations specified in this penmit must be reported to the Authority as soon as possible.

2 The following equipment stral be monitored and/or inspected within the frequency prescribed. A record of all such data shall be maintained and made avarable for Lane Regional Air Pollution Authority inspection upon request. in addition, b copy of this information must be submitted to the Lane Regional Air Pollution Authority with the Aurnual Complianco Dotemination Application.

- a Genset(s) - hours of operation - monthly

b. Standby Flare - hours of operation - montuly

\section{Emission Reduction Plan}

In acsordance with Trife 51 of the Lane Regional Air Pollution Authority Rules Regulations entitted, "Air Pollution Emergencies," the pernittee will implement the following emrissions reduction plan during air pollution episodes when so notified by this Authority. 
ERERALD PEOPLE'S UTUTYY DLSTRICT

Short Mountain Landfil Project

Permit Number 202535

\section{EPISODE LEVE.}

Alert

Waming:

Emergency:

\section{REQUIRED ACTION}

No Action

No Action

No Action

\section{Foe Schedule}

1. The company will be invoiced annually for the Compliance Determination Fee in acoordance with adopted regulations.

2 A copy of the permit application and Air Contaminant Discharge Permit must be avallable for inspection upon request 
FIELD SURVEY MAP

1985 LANE COUNTY

CULTURAL AND HISTORIC

LANDSCAPE RESOURCE SURVEY
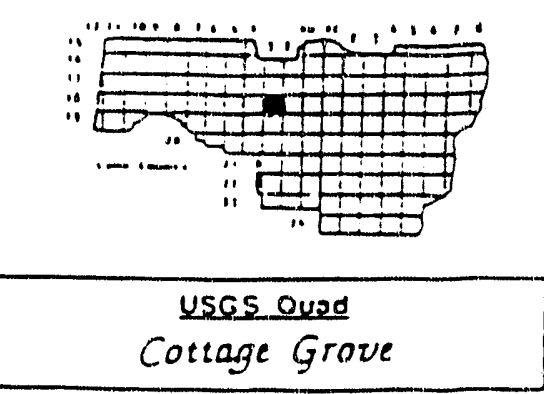

Sheet No. 9

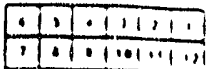

.0111101011.1111

(1)

कालाखा1'

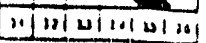

\begin{tabular}{|c|c|c|}
\hline $\begin{array}{c}\text { CULTURAL LANUSCAPE AREA } \\
\text { Coast ForK (C'F) }\end{array}$ & $\begin{array}{l}\text { usgs Ousd } \\
\text { Cottage Grove }\end{array}$ & $\frac{\text { Localion: }}{T .18 \text { R. }}$ \\
\hline
\end{tabular}

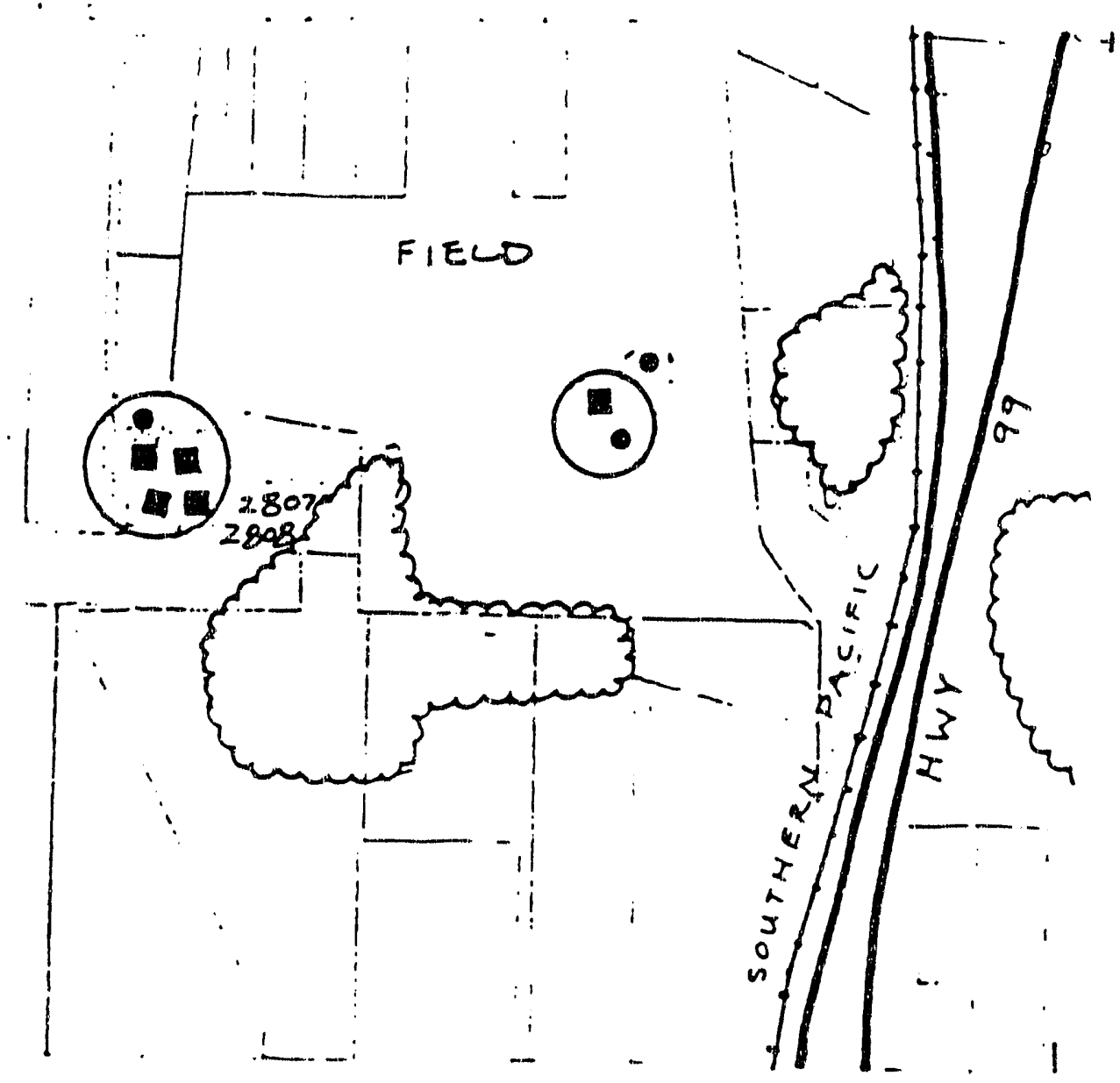

\section{MAP LEGEND}

sirculation

Tiail. Path -

Hislonic hoads

County Acadshighwars -

Naroungo Rasd $===$

A aikoso

Abandoned Aadrosd _-

Other:

LANOSCAPE EEATUAES

Rivers

Cienks

Foresi -

SMALW SEALE ELEMENTS
RUUNQAAT REMAACATIDNS

Heogerom Wincerieak - -

Urean Giomin Bouncary - - -

Land Geani or Mining Clam

Canal. Flume

$\rightarrow$

Other:

VECFIATIONALNO USE

Orchaca

Tree Farm

Vunerace

Ornamental

Pasiure

Row Crops

Crims and

Other:

\section{STRUCTUAES}

Reswonces Consincled

thefore 0.1940

Wood Bams

Farm Cluster
Senool. Churen

Grange

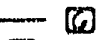

Commercial Buildong -

Mal Bulding E] E] E

Aesoris. Auid Holels

Looxes D $\square$

Lo. Mill Ponas

Abanooned Sirveluse _

Comeler

Bnogo

Covered Binge

(a)

Tunner

Other 
LANDSCAPE RESOURCE SURVEY

\section{PHOTO DOCUMENTATION OF LANDSCAPE RESOURCES}
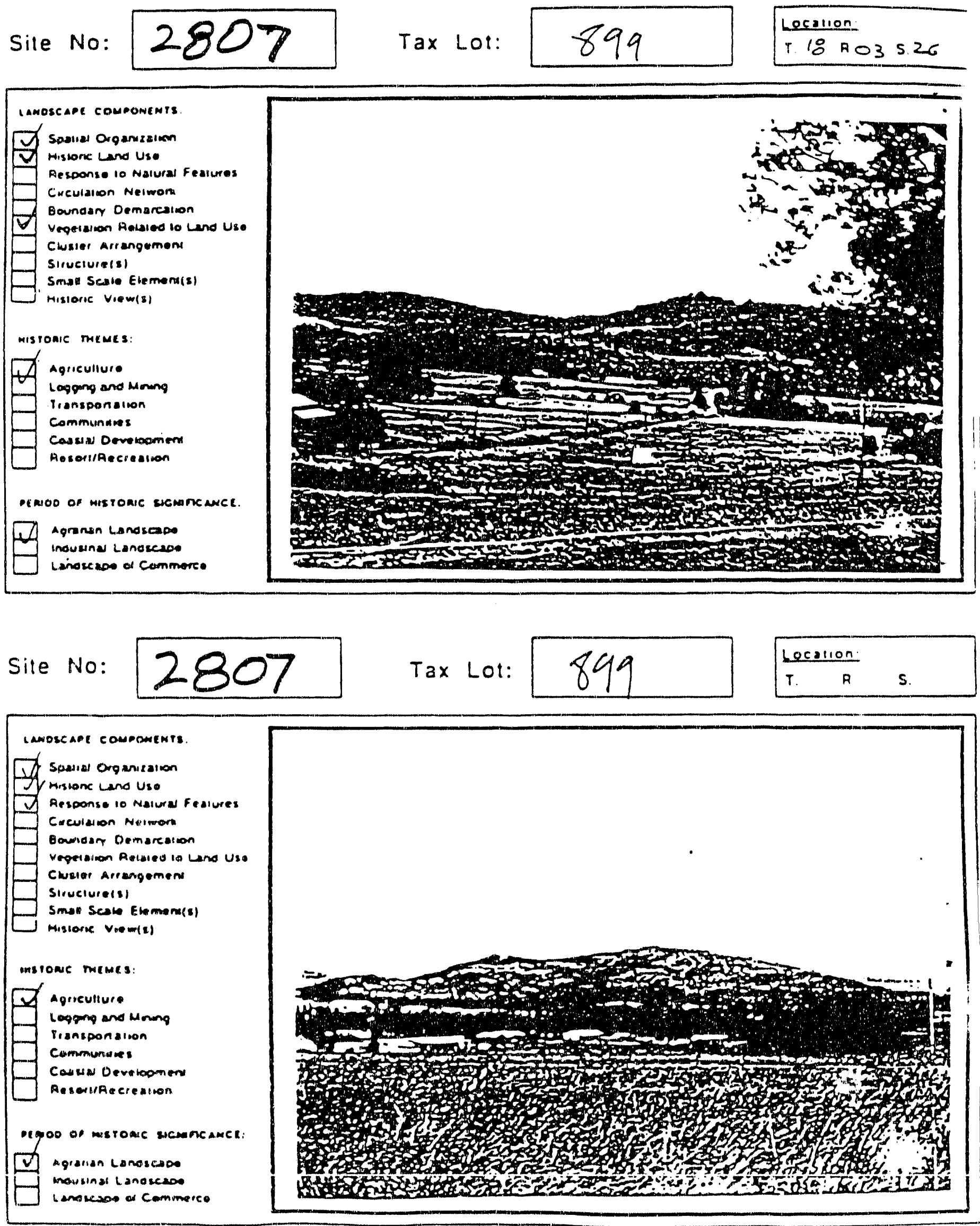


\section{PHOTO DOCUMENTATION OF LANDSCAPE RESOURCES}
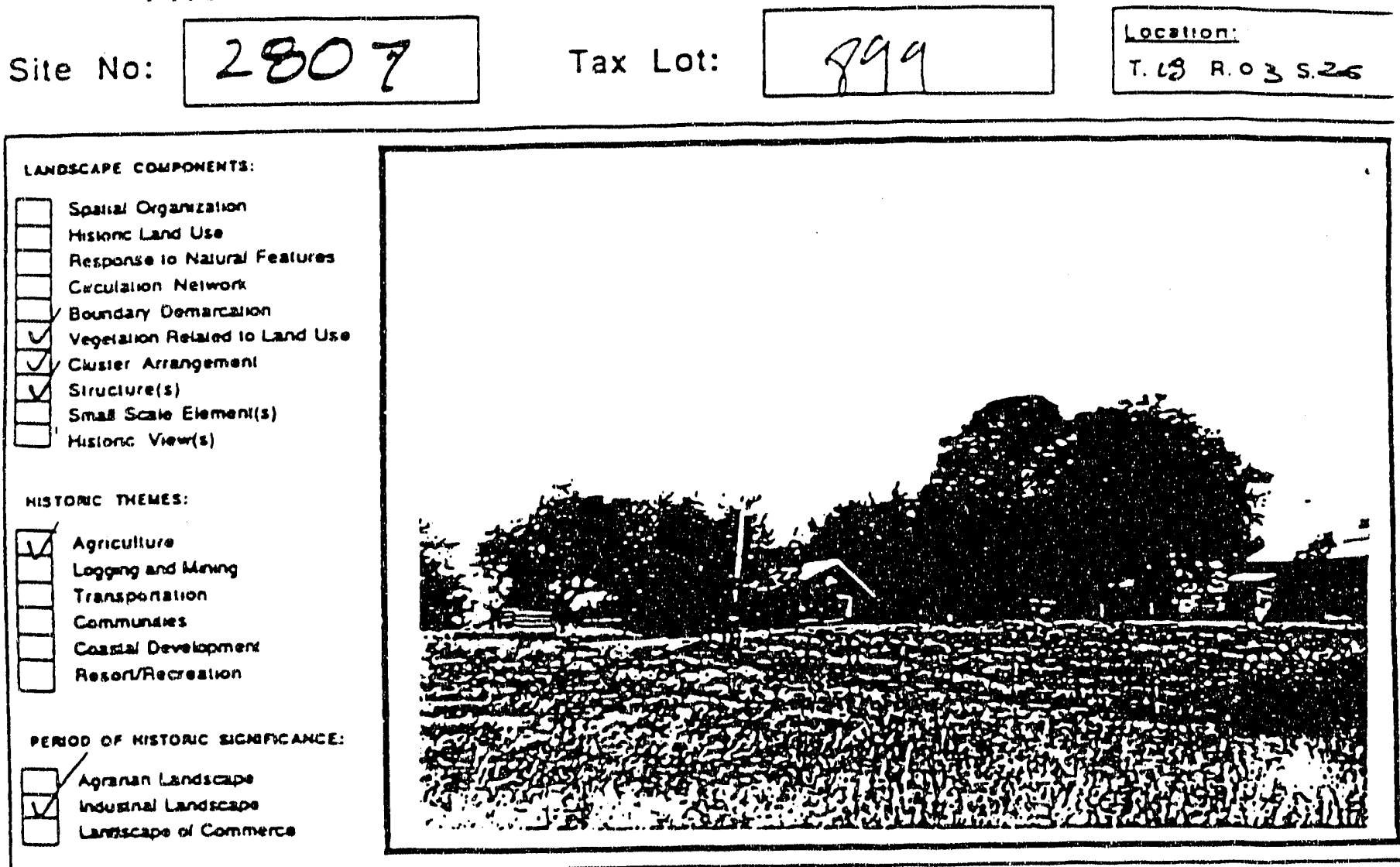

\section{Site No:

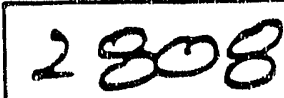

Tax Lot:

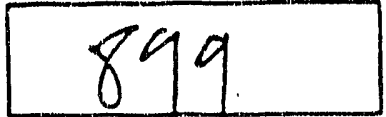

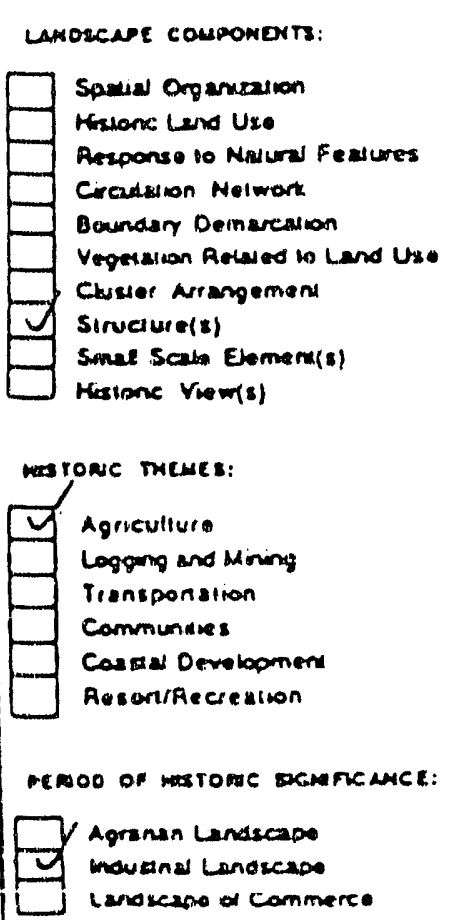

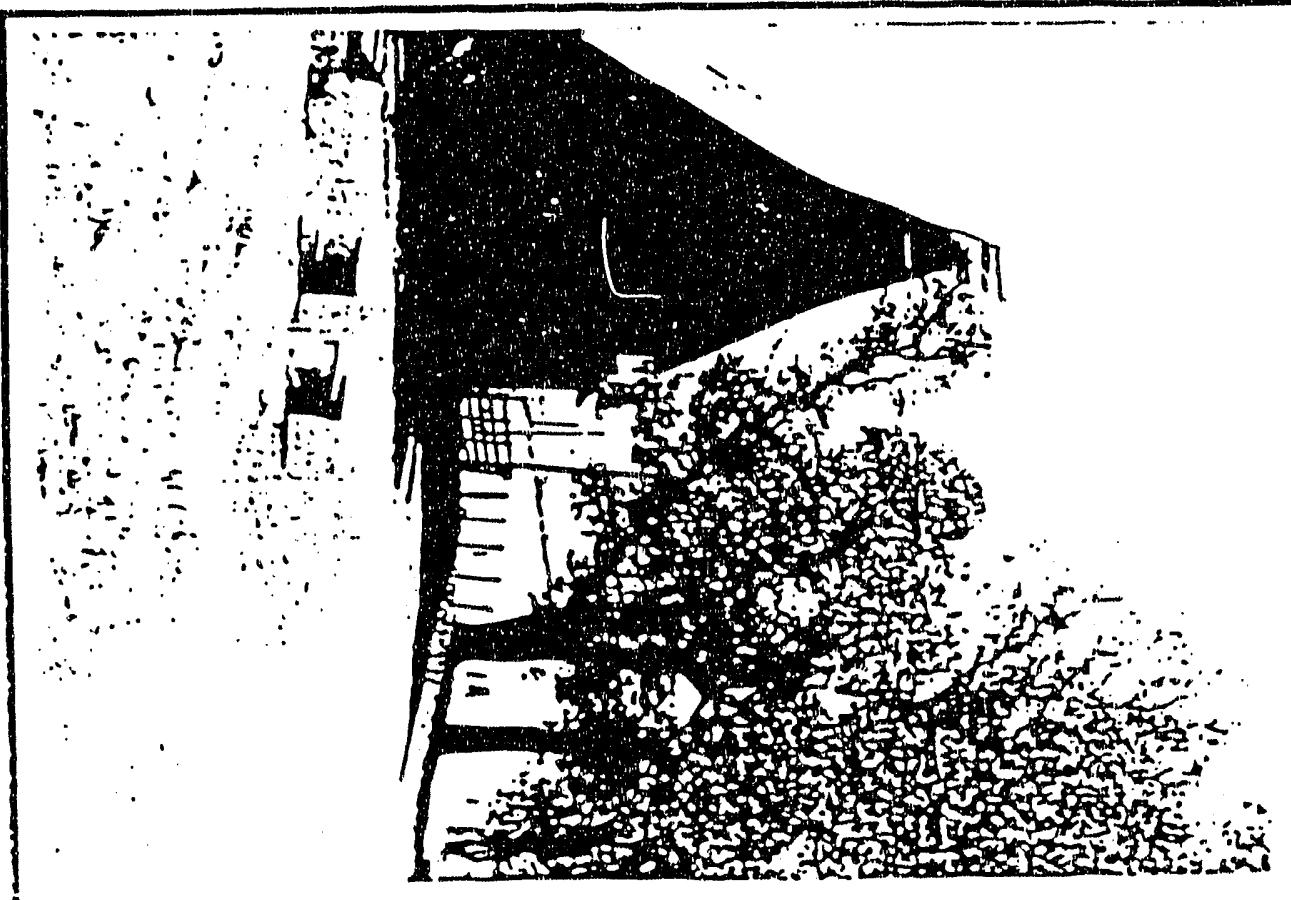




\section{PUBLIC FACILITIES ZONE (PF/RCP)}

\section{- RURAL COMPREHENSIVE PLAN}

16.219 Public Facilities Zone (PF-RCP).

(1) Purpose. The Public Facilities Zone (PF-RCP) is intended to provide land for those public and semipublic functions that provide service and are by nature an intensive or unusual use not normally associated with other zones. The zone is not intended for facilities that are primarily for an open space recreational nature, and is intended for those areas that have been included in an exception as part of the Rural Comprehensive Plan.

(2) Permitted Uses. The following uses are permitted subject to the general provisions and exceptions specified by this Chapter of Lane Code:

(a) Utilities essential to the physical, economic and social welfare of an area such as:

(i) Electric utility: electric transwission right-of-way, electric generation plant, electricity regulating substations.

(ii) Gas utllity: gas pipeline right-of-way, natural or manufactured gas storage and distribution points, gas pressure control stations.

(i1) Water utility: water pipeline right-ofway, water treatment plants, water storoge.

(iv) Sewage disposal: sewage treatment plants, sewage sludge drying beds, sewage pressure control starious.

(v) Solid waste disposal: refuse incinerstion, central garbage grinding stations, compositing plants, sanitary landfills and refuse disposal.

(b) Educational services such as:

(1) Nursery, primary and secondary education.

(1i) Colleges and professional schools.

(iii) Special training schools such as those for: vocational, trade, business, art, music, daxcing, driving, gyanestics, correspondence, etc.

(c) Religious activities, including churches, synagogues; temples, conastary or convent, etc.

(d) Welfare and charitable services:

(c) Professional membership organizations.

(f) Labor unions and similar labor organizacions.

(g) Civic, social and fraternal associations.

(b) Business assocations.

(1) Sports assembly, such as stadium, arenas and race tracks.

(j) Governmental services, such as post office, fire station and police station. 


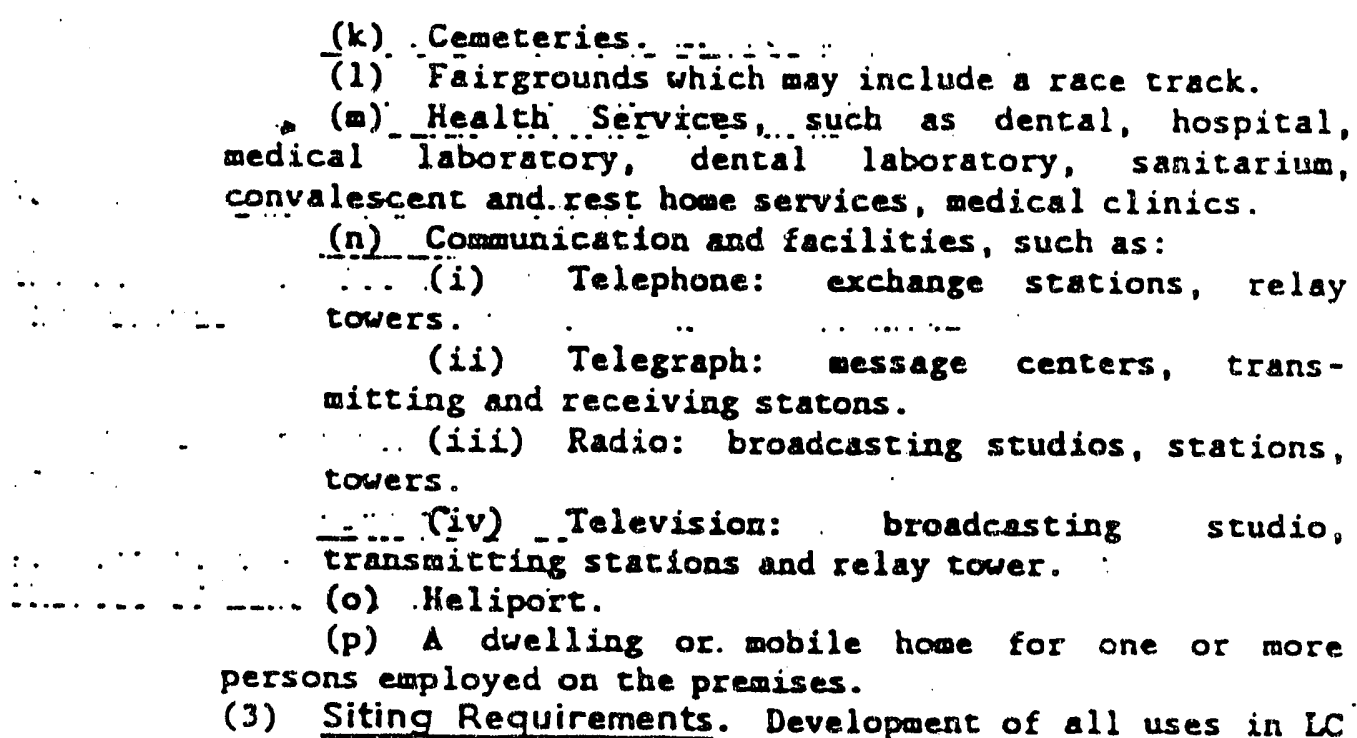

16.219 (2) above may be subject. to thie requirements of LC 16.257 site review procedures, and verification of whether or not Site Review is necessary must be made prior to developoent of a disted use.

(4) Property Development Standards. All uses or activities permitred or conditionally permitred above shall be subject to the following developmint standards:

(a) Property Line Serbacks. No structure other - than a fence or siga shall be located closer than:

(i) 20 feet from the planed right-of-way of a State road, Councy road or a local access public road specified in Lane Code Chapeer is: and

(11) 20 feet from an existing right-of-way of a stace road. Councy road or a local access public road; and

(111) 10 feet from all other property lines except as provided below.

(b) Class I Strean and Riparian Vegetation Set-

backs. No structure otber than a fence or sign shall be located closer than 50 feet from the ordinary high water of a Class I stream designated for riparian vegetation protection by the Rural Comprehensive Plan. A lessor setback may be allowed if:

(1) The Department of Fish and Vildlife is çonsulted by the Department at least. 10 days prior to issuing permit for structure: and

(11) The riparian vegetation does not actualdy extend all the way into the 50-foot setback to the location of the proposed structure, and the riparian vegetation maintenance standards; or

(i1i) An application for a variance to the above setback standard has been approved pursuant to LC 16.256 with findings of compliance to the Rural 
Comprehensive Plan policies for the protection of Class I streams and riparian vegetation.

(c) Maintenance, Removal and Replacement of Riparian Vegetaton. The following scandards shall apply for the malincenance, removal and replacement of riparian vegetation along Class I streams designated for riparian vegetation protection by the Rural Comprehensive Plan:

(i) No more of a tract's existing vegetation shall be cleared frow the setback and adjacent area than is necessary for a permitted use, accessory buildings, necessary access, septic requirements and fife safety requirements.

(ii) Construction activities in and adjacent to the setback area shall occur in such a manner so as to avoid unnecessary excavation and/or removal of existing vegetation beyond that required for the facilities indicated in LC $16.219(4)(c)(i)$ above. Where vegetation removal beyond that allowed in LC $16.219(4)(c)(i)$ above cannot be avoided, the site shall be replanted during the next replanting season to avoid water sedimentacion. The vegetation shall be of indigenous species in order to maintain the alural character of the area.

(1ii) A maximum of 25 percent of existing autural vegetation may be removed from the setback area.

(iv) The following uses and activities are excepted'from the above standards:

(aa) Comercial forest practices regulaced by the Oregon Forest Practices Act.

(bb) Vegetation removal necessary to provide water access for a water dependent use.

(cc) Removal of dead or disensed vegetation that poses a safety or health hazards.

(dd) Removal of vegetation necessary for the maintenance or placement of structure storeline stabilization.

(d) Height. None.

(e) Signs.

.. (1) Signs shall not extend over a public right-of-way or project beyond the property line

(ii) Signs shall not be illuminated or capable of movement.

(111) Signs shall be limited to 200 square

fest in area.

(E) Parking. Off street parking shall be provide in accordance with IL 16.250. 


\section{APPENDIX $\mathrm{C}$}


Recitals

Article 1: Testing and Evaluation Phase

Article 2: Operational Phase

Article 3: Payments to county

Article 4: Metering and verification

Article 5: Ose of short Mountain Landfill

Article 6: Removal of Facilities

Article 7: Security Measures

Article 8: Termination

Article 9: Warranty of Title

Article 10: Taxes

Article 11: Indemification

Afticle 12: Insurance

Article 13: Performance Bond

Axticle 14: Assignment

Afticle 15: Compliance with Laws

Article 16: Force Majeure

Article 17: Communications

Article 18: Arbitration of Disputes

Article 19: Definitions

Article 20: General 


\section{IANDFIII GAS RECOVERY AND UTIIIZATION AGREEMENT}

This Landfill Gas recovery and utilization Agreement is made this day of 1 1986, by and between the

County of Lane County, oregon, a political subdivision of the state of oregon (hereinafter referred to as county) and the Emerald People's Utility Distriet, a municipal corporation organized pursuant to Chaptex 261 of the oregon Revised statutes (hereinafter referred as Emerald).

\section{RECITAIS}

county owns and operates a land1111, commonly known as the Short Mountain Landfill, which is used for the disposal of solid wastes. County expects to dispose in the short Mountain Landfill substantially all of the solid waste that is generated in the Eugene-springeield metropolitan area and vicinity (currently approximately 250,000 tons per year), for at least the next thirty-five years.

Refuse materials in landfllis typically undergo anaerobic decomposition that produces methane, carbon dioxide, and other gases. Some of these gaseous products of anaerobic decomposition. are combustible, and some are foul-smelling. County owns and would like to recover and uttlize landlill Gas at the short Mountain Landflll in order to reduce the incidence of foul odors 
and produce revenues for the county's use. County expects to continue landfill operations at the short Mourtain Landfill while Landfill Gas recovery and utilization activities take place. Iandfill operations are the county's first priority for the short Mountain Landfill. County expects to receive revenue from Landfill Gas recovery and utilization operations as long as such operations are economically feasible. In 1985, County requested proposals for "services for Recovery of Landfill Gas," and after a public selection process, selected Emerald to provide those services.

Emerald is a publicly-owned utility that serves electricity customers in Lane county. Emerald is interested in recovering Landfill Gas from the short Mountain Landfill in order to produce electricity and waste heat. Performance by Emerald under this Agreement, including any investment by Emerald in facilities, equipment, and improvements at the short Mountain Landfill, is made in reliance on County's assurances given in this Agreement and on Emerald's independent testing and evaluation. Emerald expects to recover its investment and in addition receive net economic benefits from the Landfill Gas recovery and utilization activities over the term of this Agreement, to the mutual benefit of the parties. Emerald expects to expand its Landfill Gas facilities and operations at the short Mourtain Landill, and thereby increase net economic benefits to Emerald and county, as the volume of recoverable Landfill Gas increases over time. 


\section{ARTICIE 1 \\ Testing and Evaluation Phase}

1.1 County hereby grants to Emerald the exclusive right to. test the Short Mountain Iandeill in order to determine whether Landfild Gas can be recovered economically from the short Mountain Iandfill in Commercial Quantities. Emerald, at its sole expense, will commence testing and evaluation of the short Mountain Landill for Landfill Gas recovery and utilization.

1.2 During the Testing and Evaluation Phase, Emerald may do each and every thing, recognizing county's need for landfill operations, at the short Mountain Iandeill that is reasonably necessary or desirable for the purpose of determining the suitability and feasibility of establishing and operating Landfill Gas recovery and ut.lization facilities. . County shall . cooperate in Emerald's testing and evaluation.

1.3 The term of this easement granted by the county to Emerald for testing and evaluation is twenty-four (24) months, commencing with the date of this Agreement.

1.4 Emerald shall conduct its testing and evaluation in such a manner so as not to interfere unreasonably with county's landfill operations at the short Mountain Landfill. After completion of lts testing and evaluation, Emerald shall make reasonable efforts to return any portions of the short Mountain Landfill that Emerald has disturbed significantly to their. previous condition, except that Emerald is not obligated to 
remove any test equipment and is not obligated to fill any test wells.

1.5 Should Emerald determine in its sole judgment that the results of its testing and evaluation indicate that the short Mountain Iandfill is suitable for the economic recovery and utilization of Landfill Gas in Commercial Quantities, Emerald wild give written notice to county of its determination no later than twenty-four (24) months following the date of this Agreement.

\section{ARTICIE 2}

\section{Operational phase}

2.1 Upon giving County notice under Paragraph 1.5 above, which notice initiates the operational Phase of this Agreement, Emerald will, at its sole expense, commence and prosecute the engineering, design, govermmental authorization, procurement, construction, and operation of the necessary facilities for collecting, treating, processing, and utilizing Landfill Gas, including any facilities required to comply with any applicable and valid environmental laws and regulations. In conducting its engineering and design, Emerald shall use the services of at least one consultant knowledgeable and respected in the field of landf11l gas projects. In making design, purchase, installation, and maintenance decisions. Emerald shall seriously consider the long-range reliability consequences of its decisions with the goal (but not the obligation) of achieving 85 operating 
reliability. A general written description and a copy of Emerald's site plan shall be delivered by Emerald to county prior to the comencemant of constuction of any sad facilities. County shall have thifty (30) days atter receipt thereof to object in writing to the location of any of the facilities, improvements, or equipment, including wells, transmission lines, and pipes, to be constructed or used upon the short Mountain Landfill by Emerald, which objection may only be made if any such location of placement will unreasonably interfere with county's existing or planned landrill operations upon the short Mountain Landfill. Any such objection will be reasonable and will be specific and will include reasons for such objection and alternative locations of placements. In the event that no written objection by county is received by Emerald during said thirty (30) day period, the location of Emerald's facilities, improvements, and equipment, including but not limited to wells, transmission 2 ines, and pipes, shall be deemed approved by county. Approval by county under this paragraph 2.2 shall not be deemed satisfaction of any permit or regulatory review otherwise reguired by daw.

2.2 Upon receipt of county's objection(s) under Faragraph 2.1. Emerald sall make reasonable efforts to relocate or otherwise place such facilities, improvements, equipment, wells, transmission 1ines, or pipes in a way that will not unreasonably. interfere with county's existing or planned landfill operations upon the short Mountain Landill, consistent with Ewerald's need 
to locate or place such facilities, improvements, equipment, wells, transmission lines, and pipes, so as to optimize efficiency and productivity. Such revised locations and placements shall be submitted by Emerald to county and county shall have ten (10) days after receipt to make further written specific objections (if any of the revised locations or placements will unreasonably interfere with county's existing or planned operations upon the short Mountain Landfill), failing which such revisions shall be deemed approved. If further specific objections are made by county, the parties, acting through the operating comittee, shall make a reasonable attempt to resolve their differences pursuant to paragraph 18.2 . After such attempt, Emerald, at its election, may further revise said locations or placements to meet county's objections, or may terminate this Agreement.

2.3 once county has approved (or has been deemed to have approved) the location of any of Emerald's facilities, improvements, equipment, wells, transmission lines, or pipes, County shall not have the right to compel Emerald to move or relocate same without Emerald's prior written approval, which shall not be withheld unreasonably. County shall pay Emerald any and all costs incurred by Emerald in effecting the county's requested movement(s) or relocation(s).

2.4 After completion of the construction and necessary break-in of the facilities, Emerald will commence the collection, processing, and utilization of the Landfill Gas obtained from the

LANDEILL GAS RECOVERY AGREEMENT - 6 
Short Mountais Landill, subject to the other provisions of this Agreement. Emerald shall notify County when the initial electricity generating equipment is installed and functioning, and shall thereafter notify county whenever the installed electrical generating capacity at the short Mountain Landfill is. increased or decreased.

2.5 Emerald shall bave exclusive use of the Landfill Gas produced by or in the Short Mountain Landfill, and shall have the exclusive right to generate electricity and produce waste heat from Landelll Gas at the Short Mountain Landeill. Emerald shall have the right to do each and every thing reasonably necessary or desirable for the purpose of recovery and utilizing Landill Gas, unless expressly provided otherwise elsewhera in this Agreement. Emerald shall be deemed to have possession and control over Iande1ll Gas only when and to the extent Landfill gas has entered any above-ground pipes, collection systems, or facilities owned by Emerald.

2.6 Emerald shall conduct its construction activities and operations in such a manner so as not to interfere unreasonably with County's use of the Short Mountain Landeill. Emerald shall be responsible for the operations and production with respect to the Landf11l Gas produced by of in the Short Mountain Landfill.

2.7 Emerald shall take reasonable measures to protect its own lacillties from damage from gas migration: however, Emerald shall bave no other liability for the control or containment of or any damage occasioned by Landeill Gas migration. 
2.8 courty shall accept for disposal, at no charge to Emerald, any liquid by-products or condensate from Emerald's operations at the short Mountain Iandfill that county is allowed to accept under Oregon Department of Environmental Quality regulations.

2.9 County shall, in accordance with generally accepted safe landfill practices, deposit in the Short Mountain Iandfill substantially all of the solid wastes produced in the Eugene-springfield metropolitan area and vicinity, exclusive of toxic wastes, hazardous wastes, and Recycled Materials. Except as otherwise provided in this paragraph 2.9, so long as the short Mountain Landfill is capable of receiving additional solid wastes, within its design limits, county shall not otherwise utilize or dispose of such solid wastes. After seven (7) years, but not before, County may give notice of its intent to decrease the volume or change the composition, or both, of the solid wastes County is obligated to deposit in the Short Mountain Landfill. Such notice shall be given no less than two years in advance of when county may decrease the volume or change the composition of the solid wastes. Emerald shall have no obligation to expand or add to its facilities, improvements, equipment, wells, transmission lines, or pipes upon receiving County's notice, unless otherwise agreed by the parties. At the end of the two year notice period, the county may decrease the volume or change the composition, or both, of the solid wastes, in the manner and to the extent it notified Emerald. If such 
notice is given, County and Emerald shall negotiate appropriate economic adjustments to this Agreement. If County and Emerald cannot reach a mutual agreement on the appropriate economic adjustments to this Agreement, the matter shall be submitted to Arbitration as provided in Article 18 of this Agreement. Emerald has the sole option of continuing Landill Gas recovery and utilization operations under either the negotiated terms or those determined through Arbitration, or of terminating this Agreement pursuant to Paragraph 8.11 .

2.10 Emerald shall conduct its operations in a reasonable manner, in accordance with generally accepted work, maintenance, repair, safety, health, and enviromental practices.

2.11 Except as provided otherwise in Paragraph 2.12 below, Emerald will expand its facilities, improvements, equipment, wells, transmission lines, and pipes as warranted by increases in Comercial Quantities of Landill Gas and may decrease same as warranted by decreases in Commercial Quantities of Landfill Gas.

2.12 County expects that Emerald will place some of its Landill Gas collection facilities on or in an area of the short Mountain Landfill that is now at an interim fill depth. County intends at some time in the future to place one additional layer of landflil materials at the area that is at an interim 1 ill depth. Within three (3) months following the date of this Agreement, County shall clearly designate to Emerald the area where it intends to place an additional layer of landfild materials, and an approximate time schedule for such action. 
County will not commence placing an additional layer of landfill materials at the area of interim fill depth where Landfill Gas collection facilities are in place, thereby potentially disrupting Emerald's Landfill Gas recovery operations at that area, until or unless there is at least an equivalent amount of Landfill Gas reasonably available to Emerald elsewhere at the Short Mountain Landfill. county will, when placing an additional layer of landfill materials on the area of interim fill depth, consistent with good landfill practices, minimize disruption to interim fill areas, minimize losses of Landfill Gas, and minimize reductions in the quantity of recoverable Landfill Gas. For so long as it takes the county to complete the placing of an additional layer of landfill materials on an area of interim fill depth, any Landfill Gas produced from the interim fill depth area shall not be considered as commercial Quantities of Landfill Gas for the purposes of Paragraph 2.21 above. Emerald shall not be expected to expand its facilities, improvements, equipment, wells, transmission lines, and pipes as provided in paragraph 2.11, until and unless, and only to the extent, that the comercial Quantities of Landfill Gas reasonably available from completed fill areas (which does not include the area of interim ilil depth) exceeds the quantity of Landfill Gas reasonably available from the area of interim fill depth.

2.23 This Agreement shail remain in force for a term of ten (10) years, and shall be renewed automatically for ten year periods, and shall continue as long as Landfill Gas is produced 
and recovered in comercial Quantities (or while such obligation is excused pursuant to Article 26), unless sooner terminated in accordance with Article 8 .

\section{ARTICIE 3 \\ Payments to County}

3.1 Emerald shall pay County ten thousand dollars $(\$ 20,000.00)$ upon the parties' execution of this Agreement.

3.2 Emerald shall pay county an advance payment of two bundred flfty thousand dollars $(\$ 250,000.00)$ upon Emerald's giving written notice to the county that Emerald's initial electricity generating equipment is installed and functioning, as provided for in Paragraph 2.4 of this Agreement. The payment specified in this Paragraph 3.2 is an advance on future payments contemplated under this Agreement, and is not in addition to such payments. Payments under Paragraphs 3.4 and 3.5 shall not comence until after the total amount of such contemplated payments exceeds $\$ 250,000.00$, the amount of the advance payment.

3.3 Emerald shall have the right to use, free of costs and without obligation to make payments to county thereon, reasonable amounts of landill Gas, electricity, waste heat, and other energy and energy products produced or recovered by Emerald at the Short Mountain Landflil that are used by Emerald in connection with its Landfill Gas recovery and utilization operations. The amount of electricity used to determine payments 
under Paragraph 3.4 shall not be deemed to include the quantity of electricity used by Emerald pursuant to this Paragraph 3.3 .

3.4 Following the first notice given county under Paragraph 2.4. Emerald shall make quarterly payments to county. Each such payment shall equal twenty-two and one-half percent $(221 / 2 \%)$ of the value of the Net Electricity, measured in kilowatt-hours, generated by Emerald from utilization of the Landfill Gas in the previous quarter. The value of the Net Electricity shall be based on Emerald's average cost of electricity from sources other than the Short Mountain Landfill, as follows: For the preceeding calendar year, add the dollar amount of Emerald's demand costs to the dollar amount of Emerald's energy costs, and divide the sum of these two amounts by the total number of kilowatt-hours of electricity that Emerald handled in that year, to yield a value of electricity expressed in dollars,per kilowatt-hour (to the nearest ten-thousandth of a dollar). The resulting dollar per kilowatt-hour amount shall then be multiplied by the Net Electricity produced from the Landfill Gas during the preceeding quarter, as measured in kilowatt-hours, to determine the value of the Net Electricity. The value of the Net Electricity shall be multiplied by 0.225 to determine the amount of the quarterly payment.

3.5 During the first year of generating electricity, Emerald shall pay county quarterly payments in accordance with Paragraphs 3.2 and 3.4. Thereafter, Emerald shall pay County, unless excused under the provisions of Article 16, the greater 
of: (1) the quarterly payment calculated under Paragraph 3.4, or (2) a kinimum Payment. So long as Emerald's installed electrical generating capacity at the short Mountain Landfill following the most recent notice given under Paragraph 2.4 is greater than the: installed electrical generating capacity for the imediately preceding notice given under Paragraph 2.4, the Minimum Payment shall be the greater of: (i) fifty percent (507) of the arithretic average of the first four quarterly payments made after the most racent notice given under Paragraph 2.4 , or (ii) fifty percent (50t) of the arithmetic average of the guarterly payments made after the notice immediately preceding the most recent notice given under Paragraph 2.4 but made before the most recent such notice. When Emerald's installed electrical generating capacity at the short Mountain Iandfill following the most recent notice given under Paragraph 2.4 is less than the installed electrical generating capacity for the immediately preceding notice given under Paragraph 2.4, the Minimum Payment for the next four quarters (one year) shall be zero; thereafter, the Minimum payment shall be fifty percent (50\%) of the arithmetic average of the first four quarterly payments made after the most recent notice given under Paragraph 2.4 .

3.6 Emerald shall sumish county with a statement each quarter, comencing with the first quarter after notice is given pursuant to Baragraph 2.4 that electrical generating equipwent . that utilizes landill gas has been installed and is functioning at the Short Mountain Landfill. Each statement shall show for 
the preceding quarter the number of days of production, the total number of kilowatt-hours of Net Electricity generated at the Short Mountain Landeill by Emerald, the value of that Net Electricity (determined in accordance with Paragraph 3.4 ), the , amount Emerald is to pay County, and an estimate of the total number of kilowatt-hours of electricity generated by Emerald at the short Mountain Landfill, if such estimate can be produced at no cost to Emerald. Each quarterly statement and paynent due under this Article 3 shall be furnished by Emerald to County on the 25th day of the first month following the end of the preceding quarter of a year (three months).

3.7 Emerald may sell or use the Landfill Gas, constituent components of Landfill Gas, products of Landfill Gas, or by-products of landfill Gas, or any combination of the foregoing, instead of or in addition to generating electricity and producing waste heat from Landfili Gas, with the consent of county, which consent shall not be unreasonably withheld. Except as provided in Paragraph 3.3, payments for any sale or use of Landfill Gas by Emerald, other than using Iandfill Gas to generate electricity or produce waste heat from the generation of electricity, shall be negotiated at such time as Emerald exercises its option to make such sale or utilization.

3.8 If Emerald begins receiving revenue or value from the use (other than as provided for in Paragraph 3.3); sale, or exchange of waste heat produced by generating electricity from Landfill Gas at the short Mountain Landfill, a waste heat factor 
shall be included in the following ten year contract period. Emerald shall then include in the quarterly payments it makes to the county fifty percent (50\%) of the net revenue or value received by Emerald from the use, sale, or exchange of waste heat. from the Short Mountain Landill, less ten thousand dollars $(\$ 10,000)$ per installed engine-generator unit that produces waste heat that is actually used, sold, or exchanged by Emerald for revenue or value. The net revenue or value is the difference between the total revenue or value received by Emerald from the use, sale, or exchange of waste heat from the short Mountain Landilil and the incremental cost of making the waste heat available for use, sale, or exchange which is above and beyond the costs associated with generating electricity from Landfill. Gas.

3.9 After the first three contract periods (thirty years), commencing in the fourth ten year period provided for in Paragraph 2.13, a factor reflecting Emerald's use of fully amortized equipment shall be included in the payments Emerald makes to county under this Article 3. For purposes of this paragraph, Enerald's equipment and facilities shall, in accordance with generally accepted accounting, principles, be amortized on straight-line basis over a thirty (30) year period, commencing on the date each such equipment or facility is placed in service. If any such equipment or facility is still in service thirty (30) years after it was placed in service, Emerald shall pay county each quarter an amount equal to one-two hundred 
fortieth $(1 / 240)$ of the original cost of each such equipment or facility, provided that no such payment shall be made for any equipment or facility after it is removed from service.

\section{ARTICIE 4}

\section{Metering and Verification}

4.1 Emerald shall, at its sole expense, install meter(s) to determine the amount of Net Electricity, as measured in kilowatt-hours, generated by utilizing the Landfill Gas at the Short Mountain Landfill. Emerald shall test, or cause to have tested, the meter(s) for accuracy, before or reasonably soon after installation.

4.2 County shall have the right, upon reasonable written notice to Emerald, through -its duly authorized representative (including an independent certified public accountant), to inspect at its sole expense the records of Emerald relating to the generation of electricity from Landill Gas at the short Mountain Iandfill, in order to verify the accuracy of the quarterly payments to county. Such inspections shall be conducted during normal business hours at Emerald's place of business.

4.3 Upon reasonable written notice to Emerald, County may, at its sole expense, cause to have the metering equipment inspected and tested. Emerald shall cooperate in arranging any such inspection or test. Any such inspection or test shall be conducted by a qualified independent third party, selected by the 
mutual agreement of Emerald and County. Any such inspection or test shall be conducted in a manner that will not interrupt Emerald's electricity generation or reduce the amount of electricity generated by Emerald. Any metering equipment found" . to be defective or inaccurate by an error in registration of more than plus or minus five percent (5t) shall be repaired, re-adjusted, or replaced by Emerald at Emerald's expense.

4.4 If any of the inspections or tests provided for in Paragraph 4.3 disclose an error exceeding five percent (5t), either plus or minus, proper correction, based on the inaccuracy found, shall be made of the previous readings for the period that is the lesser of two quarters, or the period since the most recent such inspection or test, in the amount such meter shall. have been shown to be in error by such inspection or test. Any correction in statements and payments shall be made in the next quarterly statement rendered, and such correction, when made, shall constitute full adjustoent of any claim between Emerald and County arising out of such inaccuracy of the metering equipment. If any of the inspections or tests provided for herein disclose an error not in excess of five percent (5t), either plus or minus, there shall be no correction in previous statements and payments.

ARTICLE 5

Use of Short Mountain Landfill 
5.I Emerald and its employees, agents, representatives, and independent contractors shall be authorized to use that portion of the Short Mountain Iandfill and any adjacent or contiguous land owned or controlled by county, without cost (other than the payments contemplated under Article 3), to the extent reasonably necessary or convenient for Emerald's facilities and operations hereunder, including the construction, maintenance, and use of all necessary buildings, improvements, equipment, machinery, wells, pipelines, utility poles and lines, roads, gates, fences, and signs, and shall have the free right of ingress and egress at all times to and from said property. Emerald shall abide by reasonable rules provided in writing by the county for the purpose of controlling access to the Short Mountain Landfill of persons other than Emerald and its employees, agents, representatives, and independent contractors, and Emerald shall require its employees, agents, representatives, arid independent contractors to abide by such rules.

5.2 County shall make available to Emerald, without cost (other than the payments contemplated under Article 3), a mutually acceptable site on the Short Mountain Landfill sufficient in size to accomodate the construction and operation by Emerald of the Landfill Gas processing plant, electricity generating equipment, and related facilities, and Emerald shall have the free and exclusive right of ingress and egress at all times to and from the said plant site. The location and size of said plant site may be changed by the agreement of both parties 
or by arbitration.

5.3 County agrees to grant such rights of way and easements on or adjacent to the Short Mountain Landeill as may be necessary or convenient sor Emerald.

5.4 County will maintajn in reasonable condition the main access rond to and within the Short Mountain Landfill and will take no action to inhlbit Emerald's access to the plant site provided for in paragraph 5.2 or to any other portion of the Short Mountain Landili reasonably necessary or convenient for Exerald's facilities and operations hereunder. County is not obligated to maintaln any access road that is used exclusively by Emerald.

5.5 County shall add materials to, and operate, the short Mountain Landill in a manner reasonably intended to maximize the recoverable quantity of usable Landill Gas, consistent with good landill practices. County shall not unreasonably interfere with Emerald's operations at the Short Mountain Landfili.

5.6 County may continue any regular landfill operations at the Short Mountain Landili.

5.7 County and Emerald anticipate that there may in the future be uses at the short Mountain Landfill of Landfill Gas or Its by-products, other than electricity generation, including but not limited to the use of waste heat, at the short Mountain Iand111. The parties agree to cooperate in the evaluation and,. 1f reasonable, the development of such other uses of Landfill Gas or its by-products. 
5.B Except as stated herein, county reserves to itself all property rights at the short Mountain Landfill, including, but not limited to, the right to develop or permit development of portions of the site for recreational facilities, the right of reasonable and safe public access to the site, and the right to seek proposals and enter contracts for the use of resources at the site other than Landfill Gas and the organic components of the landfill materials themselves, so long as the exercise or contemplated exercise of any property right by county does not unreasonably make more burdensome, or interfere with, Emerald's operations under this Agreement.

\section{ARTICLE 6 \\ Removal of Facilities}

Emerald shall, within six months after the termination of this Agreement, remove all above-ground structures, fixtures, machines, and equipwent that Ewerald has placed on the short Mountain Landfill, except that Emerald shall have no obligation to remove any roads, foundations, and fences. Emerald shall have the right to enter the Short Mountain Landfill after the termination of this Agreement for the purpose of removing structures, sixtures, machines, and equipment. Upon termination of this Agreement, any underground collection syster at or in the Short Mountain Landfill shall become the property of county, and Emerald shall have no further responsibility or liability for such collection system. 
ARTICLE 7

\section{Security Measures}

merald shall have the right at its sole cost to install and establish those security devices and procedures it believes are reasonably necessary or desirable to protect Emerald's facilities, equipment, and other improvoments and to prevent damage or injury to property or people. Emerald and county shall each use its best efforts to prevent damage to the other's facilities, equipment, and other improvements and to promote public safety. This Article 7 sball not excuse or relieve either party from any liability attributable to its own negligence or its own intentional acts or omissions.

\section{ARTICIE B}

\section{Termination}

8.1 This Agreement wny be terminated by either party if Emerald has not given written notice to the County of Emerald's determination of suitability within twenty-four months of the date of this Agreement, as provided for in paragraph 1.5 of this Agreement.

8.2 Emerald way terminate this Agreement under the termation provisions of Paragraph 2.2 or if it is unsuccesstul. in obtaining in a timely manner any reguired governmental permit. approval, or authorization to conduct the Landfill Gas recovery and utilization activities contemplated by this Agreement. 
8.3 In the event that either party reasonably concludes that the other party is at any time not in compliance with the provisions of this Agreement, that party (first party) shall notify the other party (second party) in writing of the facts relied upon as constituting a breach hereof, and second party, if in material default, shall have sixty (60) days after receipt of such rotice in which to comply with the obligations imposed by this notice. First party shall have the right to terminate this Agreement upon written notice to second party if second party fails to comply with lawful obligations imposed by first party's notice within the sixty $(60)$ day period, unless such failure is excused by the provisions of Article 16. If the breach cannot reasonably be cured within said sixty $(60)$ day period, second party shald not be in default if second party commences to cure the default within said period and. diligently and in good faith contisues to cure the default.

8.4 County may terminate this Agreement if Emerald has not started to generate electricity from Landfill Gas by August 1 , 1989, unless such failure to generate electricity is excused by the provisions of Article 16, except that no such excuse premised on a delay in obtaining any required permit or governmental authorization shall extend beyond August. 1. 1991.

8.5 In accordance with Paragraph 2.13, Emerald may terminate this Agreement at the end of any ten (10) year contract period when Landfill Gas is no longer produced and recovered in comercial Quantities. Emerald shall give county ninety (90) 
days written notice in advance of the effective date of any termination, under this paragraph.

8.6 Emerald may terminate this Agreement at ary time there are insufficient truantities of recoverable and usable Landfill Gas at the Short Mountain Landfild to pay all of Emerald's reasonable costs of recovery and utilization of Landfill Gas, including without limitation costs of capital improvements, debt service requirements, taxes and assessments, paymerts to county, and operation and maintenance.

8.7 Emerald may terminate this Agreement at any time it determines that the total cost (expressed as dollars per kilowatt-hour of Net Electricity Emerald generates at the short Mountain Land111) of Emerald's capital improvements, debt service requirements, taxes and assessments, paymexts to county, and any other expenses of its Landfill Gas recovery and utilization operations, is greater than seventy-seven and one-half percent $(77 \mathrm{1} / 28)$ of Emerald's cost of electricity from sources other than the Short Mountain Landill (expressed as dollars per kllowatt-hourl. If Emerald so terminates this Agreement, Emerald shall pay County, as full liquidated damages, and in lieu of any and all other damages, an amount equal to four (4) quarterly Mindmum Payments then in effect, as calculated under Paragraph 3.5. These liquidated damages are agreed by the parties to be reasonable.

8.8 Emerald may terminate this Agreement if there is a substantial reduction in the quantity or quality of Landeidl Gas 
from that reasonably expected at the time of execution of this Agreement that was not caused by the fault of county or Emerald. If there has been such a reduction, county will pay Emerald one-half $(1 / 2)$ of Emerald's Prorated cost of Facility Removal and one-hale $(1 / 2)$ of the Unamortized Value of Emerald's facilities, improvements, equipment, wells, transmission lines, and pipes then in service at the short Mountain Landfill, and there shall be no further liability of either party for payments otherwise anticipated under this Agreement but not yet accrued or for any other contract damages.

8.9 Any termination may be effected only by giving written notice to the other party. Any termination effected under paragraphs 8.1, 8.2, 8.4, 8.5, or 8.6 of this Article 8 shall be without liability for any paynents otherwise anticipated under this Agreement, but not yet accrued or for any other contract damag.

8.10 In any termination effected under Paragraph 8.3 of this Agreement, either party may seek damages in a court of competent jurisdiction from the other party for any injury or loss it has sustained for any breach not cured in accordance with Paragraph 8.3. If Emerald rightfully terminates this Agreement under paragraph 8.3, the damages to which Emerald, is entitled from county shall include the Unamortized Value of Emerald's investment in its lacilities, improvements, equipment, wells, transmission lines, and pipes then in service at the short Mountain Landill and Emerald's Prorated cost of Facility Removal, plus any other damages it is entitled to under the law 
of contracts. In addition, if Emerald has made the two hunared fifty thousand dollar $(\$ 250,000)$ advance payment described in Paragraph 3.2 of this Agreement, County shall pay Emerald the sum of $\$ 250,000$ less the amount of quarterly payments, if any, determined in accordance with Paragraphs 3.4 and 3.5 of this Agreement, and if Emerald has not yet given its first notice to County under Paragraph 2.4, County shall also pay Emerald the sum of ten thousand dollars $(\$ 10,000)$ and shall reimburse Emerald for all costs Emerald has incurred to the date of termination in connection with Emerald's Landelil Gas recovery utilization operations.

8.11 Emerald may terminate this Agreement in accordance with the provisions of Paragraph 2.9. In Emerald's notice of termination under this paragraph, Emerald shall specify the effective date of termination, which shall be no more than seven (7) years after the notice is given. For such specified period the terms of this Agreement then in effect shall continue, other than as modified by Paragraph 2.9. If Emerald terminates the Agreement pursuant to this paragraph, it shall be entitled to damages calculated as of the effective date of termination. Such damages shall be determined in accordance with Paragraph 8.10, except that any damages other than the Unamortized Value of Emerald's investment in its Lacilities and Emerald's Prorated Cost of Facility Removal shall be reduced by a factor determined. by dividing the operating life of the short Mountain Landf1ll from January 1, 1977 to the effective date of termination by a 
reasonable estimate of the landfill's total operating life expectancy based on the solid waste filling conditions existing prior to any change notified by county under Paragraph 2.9 .

\section{ARTICIE 9}

\section{warranty of Title}

County hereby warrants and agrees to defend the title to the short Mountain Landfill and the Landfill Gas produced by or in the Short Mountain Landfill up to the point Emerald has control over such Landfill Gas as defined in Paragraph 2.5 ; warrants that during the term of this Agreement, and any extension thereof, Emerald shall have the quiet enjoyment of its rights under this Agreement: and warrants that there are currently no interpretations of land use restrictions imposed by or through the county that would prohibit or unreasonably interfere with any of Emerald's activities contemplated under this Agreement.

\section{ARTICLE 10}

\section{Taxes}

Emerald shall, during the term of this Agreement, pay all taxes, if any, that may be levied upon or assessed against tre plant site to be identified under Paragraph 5.2 and the facilities, equipment, and improvements constructed or installed by Emerald 1 il, on, or adjacent to the short Mountain Landfill under this Agreement which are owned by Emerald. 
ARTICIE 11

\section{Indemnification}

County and Emerald agree to defend, indemify, and hold the. other party, including the other party's officers, employees, servants, agents, and independent contractors, harmless from and against any and all claims, costs, damages, demands, actions, liabilities, or losses (including reasonable attorney fees) for injury or death to person(s) or for damage or loss to property arising out of or caused by its own operations or activities on the Short Mountain Landeill or on the contiguous or adjacent property, unless such irjury, death, damage, or loss is caused by the wrongful or negligent act of the other party or that other party's officer(s), employee(s), servant(s), agent(s), or independent contractor(s).

\section{ARTICLE 12}

\section{Insurance}

12.1 Emerald shall, during the term of the operational Phase of this Agreement, maintain insurance coverage at its sole cost, as follows: (1) Worker's Compensation insurance, as required by oregon law; (2) Personal injury and property damage insurance for injury or damage to third persons resulting from Emerald's operations under this Agreement, in a combined single. limit of not less than one million dollars $(\$ 1,000,000.00)$ for death or injury or for property damage as a result of any one 
occurrence.

12.2 Emerald shall furnish County certificates of insurance evidencing the insurance coverage required by this Article 12. Emerald shall give county notice at least thirty (30) days before, cancellation or material change in any insurance coverage required under this Agreement.

\section{ARTICIE 13 \\ Performance Bond}

13.1 Emerald shall provide, comencing with the operational Phase of this Agreement, and maintain until termination of this Agreement, a performance bond in the amount of twenty-five thousand dollars $(\$ 25,000.00)$. This bond shall guarantee the faithful performance by Emerald of all of Emerald's obligations under this Agreement. The surety shall be required to give written notice of intention to cease acting as surety at least ninety (90) days in advance of such event.

13.2 Emerald may, upon County's approval of the escrow instructions, which approval shall not be withheld unreasonably, in lieu of its obligation under Paragraph 13.1 to provide and maintain a performance bond, place twenty.five thousand dollars $(\$ 25,000.00)$ in an escrow account, with all interest from such account to be paid to Emerald. This escrow account shall guarantee the faithful performance by Emerald of all of Emerald's obligations under this Agreement. 


\section{ARTICLE 14}

\section{Assignment}

14.1 Neither County nor Emerald may sell or assign any interest it may have in this Agreement without the prior written. consent of the other party, which consent shall not be unreasonably withheld. Opon any such sale or assignment of a party's interest herein, that party shall be relieved of any further obligation hereunder as to the interest sold or assigned.

14.2 Emerald may delegate the performance of any obligation it may have under this Agreement without the prior consent of County. Emerald shall give county written notice of any such delegation. Emerald shall remain responsible for any performance it may delegate.

14.3 The terms, conditions, and provisions of this Agreement shall inure to the benefit of and be binding upon the parties hereto and their respective successors, assigns, and delegatees.

14.4 No change or division in the ownership of the short Mountain Landfill or assignment of the right to payments under this Agreement shall operate to enlarge the obligations or diminish the rights of Emerald. No change, division, or assignment of such rights shall be binding upon Emerald until thirty (30) days after Emerald has been furnished with the original or a certified copy of the instrument evidencing the 
same.

ARTICLE 15

\section{Compliance with Laws}

15.1 Emerald and county shall comply with all valid laws, rules, regulations, and executive orders of the United states and of the state of oregon and its political subdivisions that are applicable to this Landeill Gas recovery and utilization operation.

15.2 Emerald shall, at its expense, obtain and comply with all necessary governmental permits required to conduct its operations under this Agreement.

15.3 County shall, at its expense, use reasonable efforts to assist Emerald in obtaining governmental permits and approvals required to conduct Emerald's operations under this Agreement.

15.4 Emerald may contest the validity or applicability of any law, rule, regulation, or order with which it must comply under this Agreement, or the amount or legality of any taxes it is obligated to pay, or any liens for which it If y be responsible; provided that Emerald shall indemnify and hold County harmless against any loss that county suffers as a result of such contest.

15.5 At Emerald's request and sole expense, County shall 
cooperate in any contests described in Paragraph 15.4 above and shall sign any lawful instrument or document necessary to such contest. The obligations of County in Paragraphs 15.3 and 15.5 shall not apply to or affect the County in any of its roles as a. governmental agency exercising regulatory, taxing, land use, or building permit authority.

15.6

15.6.1 County and Emerald, as appropriate, shall pay promptly, as due, all persons supplying labor or material for the prosecution of the work provided for in this Agreement.

15.6.2 County and Emerald, as appropriate, shall pay promptly all contributions or amounts due to the state Industrial Accident Fund and the state Unemployment Compensation Fund from County or Emerald or any subcontractor in connection with the performance of this Agreement.

15.6:3 County and Emerald shall not permit any lien or claim to be filed or prosecuted against Emerald or County on account of any labor or material furnished.

15.6.4 County and Emerald, as appropriate, shall pay to the Oregon Department of Revenue all sums withheld from employees pursuant to ORS 316.167.

25.6.5 If county or Emerald fails, neglects, or refuses to make prompt payment of any claim for labor or material furnished to it or its subcontractor by any person in connection. with this Agreement as such claim becomes due, the other party may pay such claim to the person furnishing the labor or material 
and charge the amount of payment against funds due or to become due to the first party by reason of this Agreement. The payment of a claim in the manner authorized hereby shall not relieve the nonpaying party, or its surety, from its obligation with respect. to any unpaid claim.

15.6.6 County or Emerald, as appropriate, shall

promptly, as due, make payment to any person, copartnership, association, or corporation furnishing medical, surgical, and hospital care or other needed care and attention, incident to sickness or injury, to its employees, of all sums which it agrees to pay for such services and all moneys and sums which it collected or deducted from the wages of employees pursuant to any law, contract, or agreement for the purpose of providing or paying for such service.

15.6.7 County and Emerald shall employ no person for more than eight hours in any one day, or forty hours in any one week, except in cases of necessity, emergency, or where the public policy absolutely requires it. In such cases, county or Emerald, as appropriate, shall pay the laborer at least time and a half pay for all overtime in excess of eight hours a day and for work performed on saturday and on any legal holidays specified in ORS 279.316 . Notwithstanding the foregoing, the provisions of oRs 279.340 and 279.342 shall apply.

15.6.8 The hourly rate of wage to be paid to workers upon all public works shall be not less than the prevailing rate of wage for an hour's work in the same trade or occupation in the: 
locality where such labor is performed, in accordance with ORS 279.348 to 279.356 , or ORS $261.345(2)$, as may be applicable.

15.6.9 Emeradd and County agree to make all provisions of this Agreement applicable, as appropriate, to any subcontractor performing work under this Agreement.

ARTICLE 16

\section{Force Majeure}

16.1 This Agreement shall not be terminated, in whole or in part, except as provided in Paragraphs 8.2 and 8.4 , nor shall either party be held liable in damage, for failure to comply her ith, if compliance is prevented by, or the failure is a result of, any low, order, ordinance, rule, regulation, or action. (other than by Emerald or county), or due to force majeure. The term "force majeure" as used herein shall mean an event or condition beyond a party's reasonable control, including, but not limited to, ar act of God or nature; catastrophe; labor disturbance: unreasonable delay in obtaining any required permit or govemmental authorization; war: sabotaze; underground conditions, site conditions, or chemical or organic substance(s) causing damage to Emerald's equipment or fleilities, any of which" were not reasonably discoverable at the time of design and construction of Emerald's Landfill Gas recovery and utilization facilities; unavailability or delays in delivery of any product, 
labor, fuel, service, or matemind: or failure or breakdown of Emerald's equipment that requires the equipment not be used for thirty days or longer period of time.

16.2 If Emerald's operations are at any time prevented or. affected by any of the causes referred to in Paragraph 16.1, the performance of its obligations to the extent so prevented or affected shall be excused without liability hereunder, and this Agreement shall continue in full force and effect.

\section{ARTICIE 17}

\section{Communications}

17.1 Any notice or communication to be given under this Agreement shall be in writing. Notices may be hand-delivered or sent by regular onited states mail, postage prepaid, and properly addressed. Notices shall be considered duly given and received on the second weekday after the date of mailing, except for any notices that are required by this Agreement to be actually received by the party to whom sent.

17.2 All nocices to be sent to county shall be sent to:

Lane County Waste Management Division

Public service Building

125 East 8th

Eugene, OR 97401

ATTN: Craig starr

17.3 All notices to be sent to Emerald shall be sent to:

Enerald People's Utility District

5001 Franklin Blvd

Eugene, OR 97403

A.TN: Stephen E. PaIT

LANDFIIL GAS RECOVERY AGREEMENT" - 34 
17.4 Either party may change the address at which it is to receive notice by written notice of such change of address given to the other party.

\section{ARTICIE 18 \\ Arbitration of Disputes}

18.1 All controversies or claims arising out of or relating to this Agreement shall be governed by the provisions of this Article 18 and by the provisions of Paragraph 8.10 .

28.2 County and Emerald agree to create an operating Committee in orjer to facilitate cooperation and to avoid and resolve disputes relating to operations at the short Mountain Iandfill. County and Emerald shall each appoint two persons to . serve on the operating committee. The operating comittee may meet from time to time to sacilitate cooperntion and to attempt to resolve any controversy or claim arising out of or relating to this Agreement by negotiating in good faith. The parties may, by mutual agreement, use a mediator to facilitate such negotiations.

18.3 In the event that any controversy or claim arising out: of or relating to this Agreement, or any breach thereof, is not settled by negotiation, such controversy or claim shall be settled by arbitration in accordance with the commercial Arbitration Rules of the American Arbitration Association then in effect, and judgment upon the award rendered by the Arbitrator(s). may be entered in any oregon court having jurisdiction thereof. 
This Agreement's terms and conditions, which establish the arbitrator's power to resolve disputes, are jurisdictional. Whenever possible, such terms and conditions shall be strictly construed to effect the plain meaning of the parties' contract. To the extent not inconsistent with the comercial Arbitration Rules of the American Arbitration Association, the rules of evidence and procedure applicable in the circuit court of oregon for lane ccunty shall apply to any arbitration conducted under this Paragraph 18.3 .

18.4 In the event that there are no comercial Arbitration Rules of the American Arbitration Association then in effect, the provisions of ORS 33.220 to 33.340 (1985) shall control.

\section{ARTICIE 19 \\ Definitions}

19.1 Commercial Quantities: Amounts of Landfill Gas deemed by Emerald in its sole judgment to be sufticient to pay for all costs of recovery and utilization of Iandfill Gas, including without limitation costs of capital improvements, debt service requirements, taxes and assessments, payments to county, and operation and maintenance, plus a reasonable amount in addition to all such costs.

19.2 Landeill Gas: Any and all gases, including but not dimited to wethane and carbon dioxide, that are produced by decomposition of material in or at the short Mountain Landfill: the term Landflil Gas also includes any and all components or 
products recovered in association with such gases.

19.3 Net Electricity: The quantity of electricity produced by Emerald from Landfill Gas at the Short Mourtain Landfill, less the quantity of electricity used by Emerald for the collection,. treatment, processing, and utilization of landfili Gas and any of its byproducts, including reasonable losses associated with the transformation of electricity generated at the short Mountain Landfill.

19.4 Prorated Cost of Facility Removal: For the purposes of Paragraphs 8.8 and 8.20, the Prorated Cost of Facility Removal shall be the reasonable costs for physically removing Emerald's facilities, improvements, equipment, transmission lines, and pipes still in service as provided in article 6 less one-thiftieth $(1 / 30)$ of such reasonable costs for each full year each such item has been in service.

29.5 Recycled Materials: Any inorganic materials, clothing, newspaper, cardboard, used dimensional lumber, and up to ten thousand $(10,000)$ cubic yards of yard debris which are never delivered to a county solid waste facility for landfill disposal because of comercial or source-separated recycling, even if such recyciling is sponsored or conducted by the county. The volume of yard debris that qualifies as Recycled Materials under this Paragraph shall be adjusted, if necessary, so that such volume in any future year shall have the same relationship. to 10,000 incoming cubic yards as the population of the Eugene-springlield standard metropolitan statistical area in that 
future year shall have to the present population of 200,000 .

19.6 Short Mountain Landfill: The real property owned by county and currently operated by county as a solid waste disposal facility, illustrated in Exhibit " $A$ ", and further described as follows:

The East $1 / 2$ of the Northeast $1 / 4$, the Northeast $1 / 4$ of the southeast $1 / 4$, section 35 ; the Northwest $1 / 4$, the West $1 / 2$ of the Northeast $1 / 4$, the North $1 / 2$ of the Southeast $1 / 4$, the North $1 / 2$ of the Southwest $1 / 4$, and Lots 1,2 , 3 , and 4 of section 36 , all in Township 18 South, Range 3 West of the Willamette Meridian, in Lane county, oregon: EXCEPTING that portion lying westerly of the Easterly line of property conveyed to Oregon State Highway Commission, by Deed recorded November 4, 1953, Reception No. 16251, Iane County Oregon Deed Records, and by Deed recorded April 28, 1950, in Book 414, Page 57, Lane County Oregon Deed Records, in Lane county, oregon.

19.7 Unamortized Value. For purposes of Paragraphs 8.8 and 8.10, the Unamortized Value of each of Emerald's facilities, improvements, equipment, wells, transmission lines, and pipes is the original cost of each such unit less one-thirtieth $(2 / 30)$ of its original cost for each full year the unit has been in service.

ARTICLE 20

\section{General}

20.1 Obligations of Parties: All obligations of county and Emerald under this agreement are expressly set forth herein, and no other obligation or covenants are to be implied hereunder. 
20.2 Entire Agreement: This Agreement is intended by the parties to constitute a complete, final, and exclusive expression of their agreement with respect to the subject matter hereof. There are no promises, terms, conditions, or obligations other: than those contained herein. This Agreement shall supersede all. prior communications, representations, or agreements, either oral or written, between the parties.

20.3 Modification: This Agreement shall not be changed or modified except by a subsequent agreement in writing signed by both parties.

20.4 Waiver: The waiver by either party of any failure on the part of the other party to perform in accordance with any of the terms or conditions of this agreement shall not be construed as a waiver of any future or continuing failure, whether similar or dissimilar thereto.

20.5 Headings: The headings or captions at the beginning of each article or at the beginning of a paragraph are not intended to act as a limitation on th: scope or meaning of the article or paragraph itself. The headings or captions are included for the convenience of the reader only.

20.6 Construction: Each party has been represented by counsel during the negotiations leading up to the drafting and execution of this Agreement. Each party has thoroughly reviewed. this Agreement and the exhibits which are attached hereto with. that respective party's counsel. The rule of construction of a written agreement as construed against the party preparing or 
drafting such agreement shall specifically not be applicable to the interpretation of this Agreement.

20.7 Exhibits: All exhibits attached to this Agreement shall be deemed part of this Agreement and incorporated herein,. where applicable, as if fully set forth herein.

20.8 Warranty of Authority: Each party hereby warrants that the execution and delivery of this Agreement and the performance of such party hereunder have been authorized by all necessary actions, that the person or persons executing this Agreement on behalf of such party are competent and fully authorized to do so, and that the execution of this Agreement is the lawful and voluntary act of such party.

20.9 Severability: Invalidation of any term or provision . herein by judgrent or court_order, or otherwise, shall not affect any other provisions, which shall remain in full force and effect.

20.10 Execution of Other Documents: The parties agree to execute whatever documents are necessary to effectuate the purposes of this Agreement.

20.12 Persons Affected: This Agreement is not intended to nor shall it confer any right or benefit whatsoever upon any person or entity other than the parties hereto. Nothing in this Agreement shall be construed to create any duty to, any standard of care with reference to, or any liability to any person not a party to this Agreement.

20.12 Several obligations: Except where specifically stated LANDFILL GAS RECOVERY AGREEMENT - 40 
in this Agreement to be otherwise, the duties, obligations, and liabilities of the parties are intended to be several and not joint or collective. Nothing contained in this Agreement shall ever be construed to create an association, trust, partnesship, oy. joint venture or impose a trust or partnership duty, obligation, . or liability on or with regard to either party. Each party shall be individually and severally liable for its own obligations under this Agreement.

20.13 Simultaneous Execution: This Agreement shall be simultaneously executed and delivered in two counterparts, each of which when so executed and delivered shall be deemed to be an original, and shall constitute one and the same instrument.

IN WITNESS WHEREOF, the parties hereto have caused this Agreement to be executed in their respective names as of the date first above written.

COUNTY OF IANE COUNTY

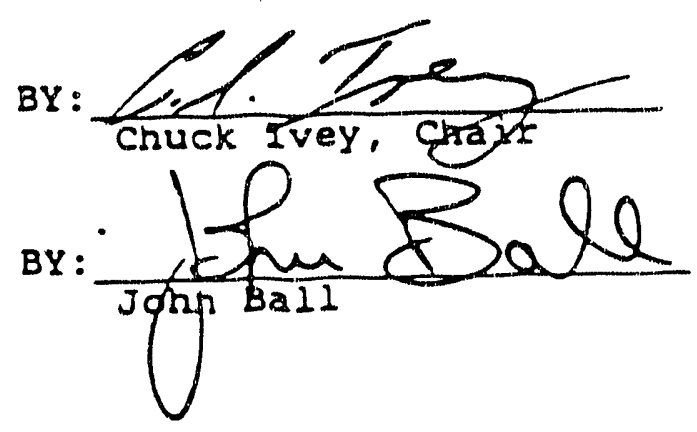

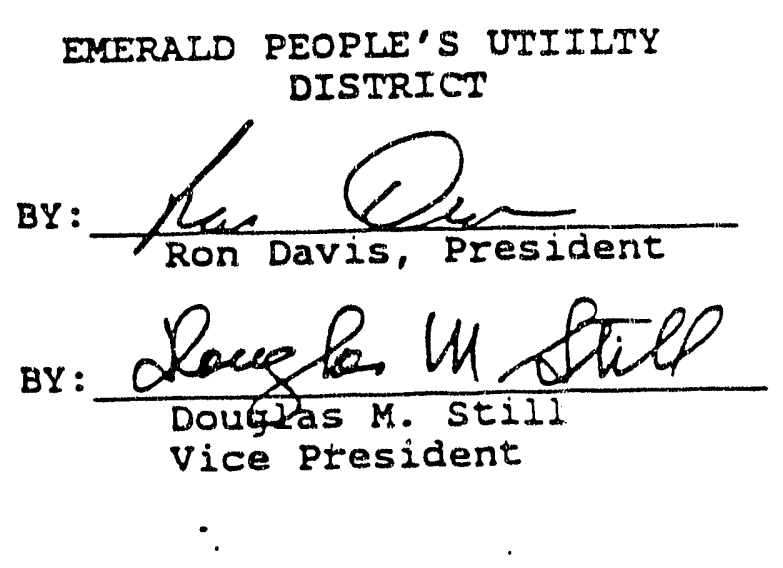

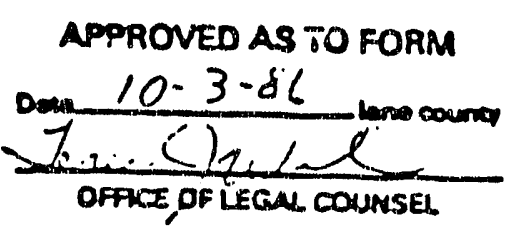


BY :

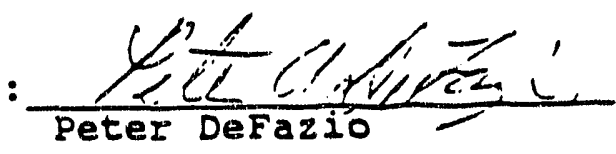

BY: $\frac{\text { Biee Rogen }}{\text { Bili Rogers }}$

BY:
BY: $\frac{\text { Sinhix Unspusen }}{\text { Shgrid Rasmussen }}$

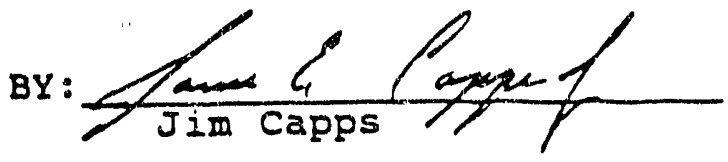

BY: $\int_{\text {Dick Eymann }}$ 
$\left[.0^{9} \cdot\right.$

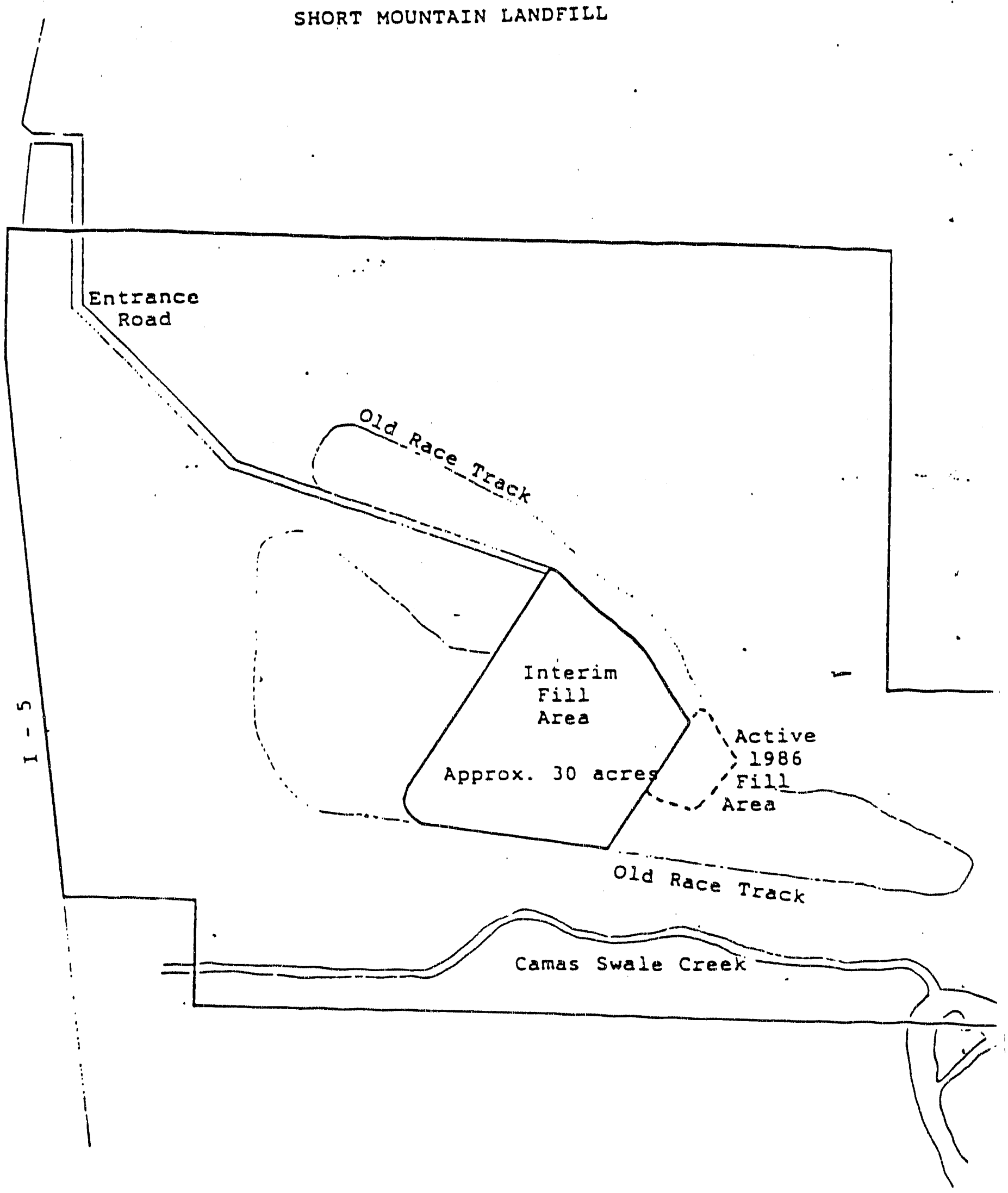




\section{AMENDMENT 11 TO LANDEILL GAS RECOVERY \\ AND UTILIZATION AGREEMENT BETWEEN THE COUNTY OF LAND AND THE FMERALD PEOPLE'S UTILITY DISTRICT}

For valuable consideration received, this Amendment 1 modifles the wande12l Gas recovery and utillzation Agreement made the 17th day of september. 1986, by and between the County of Lane County, Oregon (County) and the Emerald People's utility Dlstrict (Emerald).

(1) Paragraph 1.3 of Article 1 shadi read as follows:

1.3. The easement granted by the county to Emerald for testing and evaluation shall not be terminated before December 31 , 1988."

Paragraph 1.5 of Artlcle 1 shall read as follows:

-1.5. Should Emerald determine in its sole fudgment that the results of its testing and evaluation indicate that the short Mountain Landfill is sultable for the economic recovery and utilization of Landelli gas in Commerclal Quantities, Emerald shall give written notice to county of its determination no later than December 31, 1988."

IN WITNESS WHEREOF, the parties hereto have caused this Agreement to be executed in their respective names on this 2157 day of JUNE - 1989.
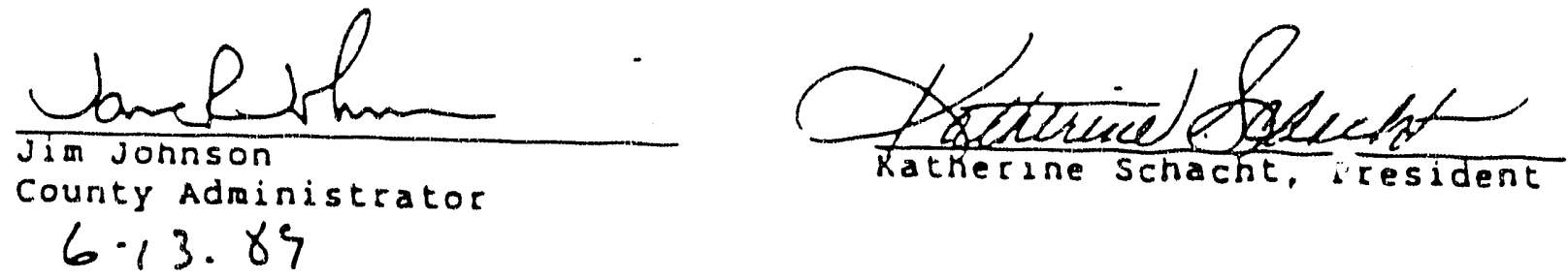

6.13 .89 


\section{AMEANDHEATT 3 TO LANDPTLL GAS RECOVERT \\ AND UTTHTZATION ACRREATRANT BETHEEN \\ LANE COUNTI AND TEB EMTERALD PEOPLE'S UTILTTY DISTRICT}

This Amendment 3 modifies the Landf 111 Gas Recovery and Utilization agreement made the 17th day of September, 1986, by and between Lane County (County) and the Emerald People's Utility District (Emerald).

Amend the language in Paragraph 8.4, in its entirety, to read as follous:

8.4 "County may terminate this Agreement if both of the following conditions exist on December 1, 1991: (1) Emerald has not started to generate electrictiy and (2) Emerald has not signed contracts for the purchase of equipment for, or other development of, its operations at the Short Mountain Landf1II and has not spent seventy five percent (75z) of the contract price for the construction of facilities for the recovery and utilfzation of landfill gas. Bovever, the date on which generation shall occur shall not go beyond July 1 , 1992 unless such fallure to generate electriclty is excused by the provisions of Article 16, except that no such excuse premised on delay in obtaining any required permit or govermmental authorization shall extend beyond December 1 , 1993."

Add to the end of Paragraph 19.9 the following nev language:

19.9 "In the event that Emerald pays for any of $i$ ts development and construction out of revenues, Emerald's costs for the purpose of calculating the value of operating arargin shall be annualized and shall include an in-lieu debt service charge as if Emerald had issued tax-exempt bonds and incurred an actual annual debt service. The in-lieu interest rate to be used for this purpose shall be the most recently listed State of Oregon A rated, 20 year bond index published trice monthly in the Oregon Bond Calendar by the Municlpal Debt Advisory Comission through the Oregon State Ireasury, plus the difference between the "20 Bond G.0. Index", and the "25 Bond Revenue' Index" as listed in the trade magazine "Bond Buyer". The in-lieu interest rate shall be separately calculated and determined each rime capital funds are acquired over the life of the project."

All other terms and conditions of the original agreement not amended herein are to remain in full force and effect.

LANE COUNTY

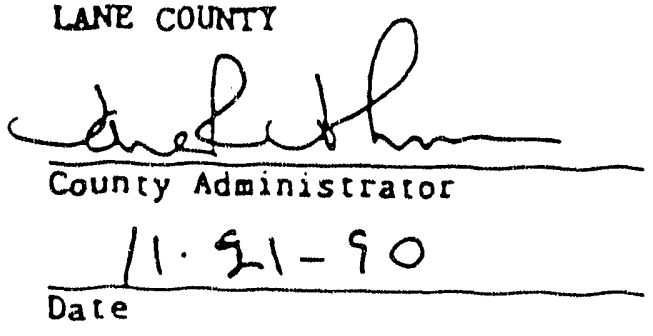

EMERALD PEOPLE'S UTILTTY DISTRICT

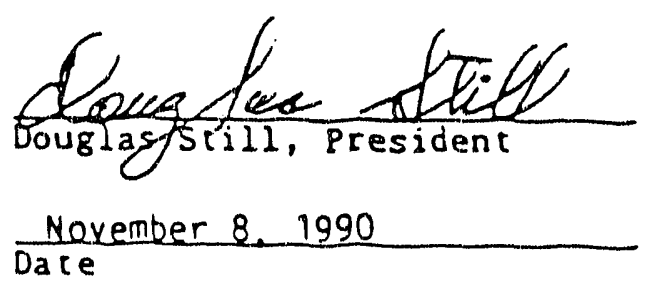

A.PBAOVED AS TO FORM

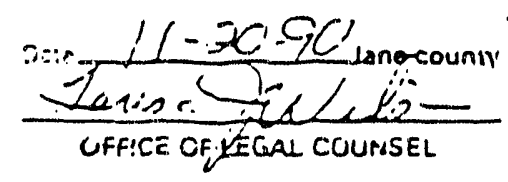




\section{AMENDMENT 2 TO LANDFILL GAS RECOVERY AND UTILIZATION AGREEMENT BETWEEN THE COUNTY OF LAND AND TBE EMERALD PEOPLE'S UTILITY DISTRICT}

For valuable consideration recelved, this Amendment 2 modlfies the Landelil Gas recovery and utliliation Agreement made the $17 \mathrm{th}$ day of september, 1986 , by and between the county of lane county, oregon (County) and the Emerald people's Utility District (Emerald).

(1) Paragraph 1.5 of Article 1 shall read as follows:

1.5. Should Emerald determine in its sole judgment that the results of its testing and evaluation indicate that the short mountain Landeili is suitable for the economic recovery and utilization of Landfill Gas in Commercial Quantities, Emerald shall give written notice to County of its determination no later than ocrober 1, 1989."

(2) Paragraph 3.2 of Article 3 shall read as follows:

3.2. Emerald shall pay county an advance payment of twenty-five thousand dollars $(\$ 25,000.00)$ upon Emerald's giving written notice to the County that Emerald's inltial electricity generating equipment is installed and functioning, as provided for in paragraph 2.4 of this Agreement. The payment specified in this Paragraph 3.2 is an advance on future payments contemplated under this Agreement, and is not in addition to such payments."

Arendment - Page 1 
(3) Paragraph 3.4 of Article 3 shald read as follows:

3.4. Following the first notice given County under paragraph 2.4, Emerald shall make quarterdy payments to County. Payments contemplated under this paragraph 3.4 shald not commence unt1l after the total amount of such contemplated payments exceeds the sum of twenty-Eive thousand dollars $(\$ 25,000)$ plus any Minimum ayments made pursuant to Paragraph 3.5. Each payment under this paragraph shall equal the greater of (1) four and Eive tenths percent $(4.58)$ of the value of the Net Electricity, measured in kilowat-hours, generated by Emerald from utilization of the Landfild Gas in the provious quarter, or (2) one-half of the value of the operating Margin.

(4) Paragraph 3.5 of Article 3 shall read as follows:

"3.5. During the first year of generating electricity. Emerald shall pay County quarterly payments in accordance with Paragraphs 3.2 and 3.4 . Thereafter, Emerald shall pay county, unless excused under the provisions of Article 16, the greater of: the quarterly payment calculated under Paragraph 3.4, or (2) a Minimum Quarterly Payment of $\$ 3,750$.

(5) Paragraph 5.2 of Areicle 5 shall read as follows:

-5.2. County shall make available to Emerald. without cost (other than the payments contemplated under Article 31 , a mutualiy acceptable site or sites on the short mountain Land 111 sugficient in size and adequate in location to accomodate the construction and operation by Emerald of Landilil Gar processing plant. electricity generating equipment, and related facilities, and Emerald shald hove the free and exclusive right of ingress and egress at ad times to and frora the said plant site(s). The location and size of said plant site(s) may be changed by the agreement of both parties or by arbitration."

Amendment - Page 2 
(6) Paragraph 8.1 of Acticle 8 shall read as follows:

* B.1. This Agreement may be terminated by elther party if Emerald has not given written notice to the County of Emerald's determination of suitability within the time provided for in paragraph 1.5 of this Agreement."

Paragraph 8.4 of Article 8 shall read as follows:

-8.4. County may terminate this Agrement if Emerald has not started to generate electriclty from landfill cas by December 1, 1990 unless such fallure to generate electricity is excused by the provisions of Article 16, except that no isuch excuse premised on a delay in obtaining any required permit or governmental authorization shall extend beyond December 1., $1992 . "$

Paragraph 8.10 of Article 8 shall read as follows:

"8.10. In any termination effected under Paragraph 8.3 of this Agreement, ejther party may seek damages in a eourt of competent jurisdiction from the other party for any injury or loss it has sustainad for any breach not cured in accordance with paragraph 8.3 . If Emerald righteully terminates this arcement under paragraph 8.3 . the damages to which Emerald is entitled from County shall include the Unamortized Value of Emerald's investment in its facilities, improvements, equiprent, wells, transmission lines, and pipes then in service at the short Mountain Landflll and Emerald's prosated Cost of Facility Removal, plus any other damages it is entitled to under the law of contracts. In addition, if Emerald has made the twenty-five thousand dollar $(\$ 25,000.00)$ advance payment. described in paragraph 3.2 of this Agreement. County shall pay Exerald the sum of $\$ 25,000.00$ plus the amount of Minimum payments emerald made pursuant to paragraph 3.5 , less the amount of quarterly payents, if any, deterained in accordance with paragraph 3.4 . and if Emerald has not yet given its first

Amendment - Page 3 
notice to county under paragraph 2.4. County shall also pay Emerald the sum of ten thousand dollars $(\$ 10,000.00)$ and shall reimburse Emerald for all costs Emerald has incursed to the date of termination in connection with Emerald's Landfill Gas recovery utilization operations."

(9) Paragraph 17.2 of Article 17 shall read as follows:

"17.2. All notices to be sent of county shall be sent to:

Lane County Was : Management Division

Public service building

$125 \mathrm{E}$. 8th Avenue

Eugene, OR 97401

ATTN: Michael Turner"

(10) Pagagaph 17.3 of Arrfcle 17 shall read as follows:

117.3 . All notices to be sent to Emerald shall be sent to:

Emerald People's Utility District

33733 Seavey LOop Road

Eugene, OR 97405

ATTN: Alan zelenka"

(11) New Paragraphs 19.8 and 19.9 of Article 19 shald read as Eollows:

"19.8. Value of Net Electricity. The value of the Net Electricity shall be based on Emerald's average cost of electricity from sources other than the short Mountain landfill, as follows: For the preceding calendar year, add the dollar amount of Emerald's demand cost to the dollar amount of Emerald's energy costs, and divide the sum of these two amounts by the total number of kllowatt-hours of electricity that Emerald handled in that year, to yield a value of electricity expressed in dollars per kilowatt-hours (to the nearest ten-thousandth of dollarl. The resulting dollar per kilowat-hour amount shall then be multiplied by the Net Electricity produced from the 
Landitil Gas during the pieceding quarter, as masured in kilowatt-ilours, to determine the value of the Net Electricity."

-29.9. Value of the operating Margin. The ralue of the Ner Electricity, as calculated in accordance. with paragraph 3.4 , less all Emerald's reasonable costs for its facilities and operations relating to the Short Mountain Landeild Gas Recovery project. under this contract for the previous quarter, which costs include: capital, construction. and debt service costs; labor and fringe costs; operation, repair, replacement, mainrenance, and equipment expenses: insurance. defense, and claims costs; contracted services;l taxes; supplies; reasonable administrative costs; and legal and governmental or other fees lexcluding payments to county described in paragraphs $3.2,3.4$, and $3.5 \%$..

All other terms and conditions of the original areement not amended herein are to remain in full force and eEfect.

IN WITNESS THEREOF, the parties hereto have caused this Agreement to be executed in their respective names on this 2159 day of JUNE

county of Lane county

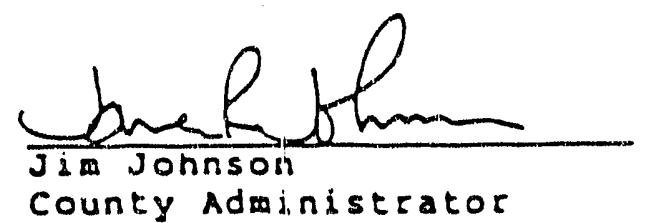

$C-, 3.89$

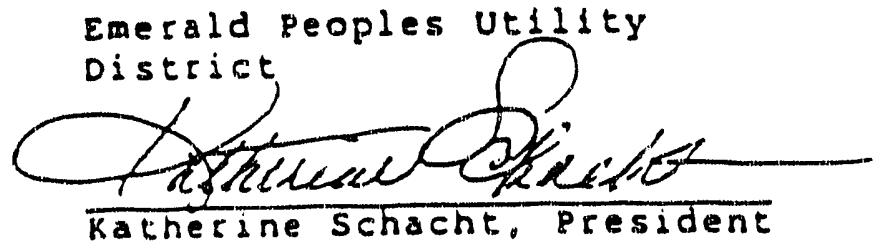

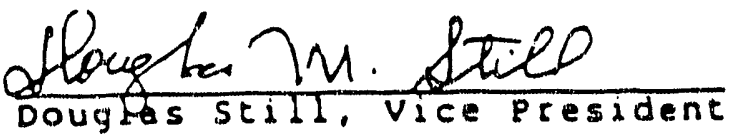




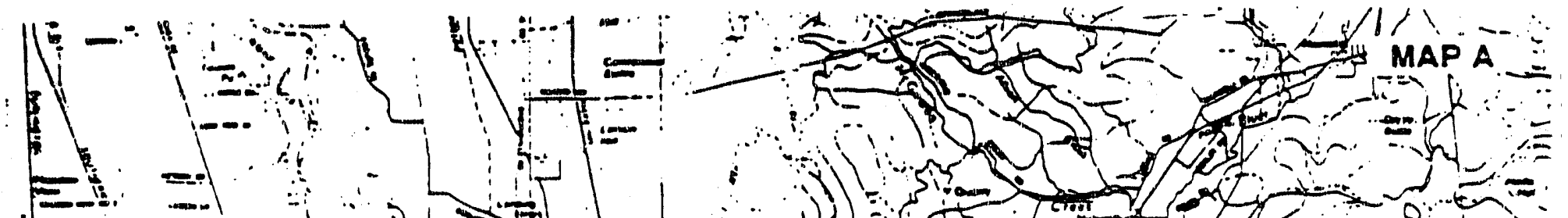

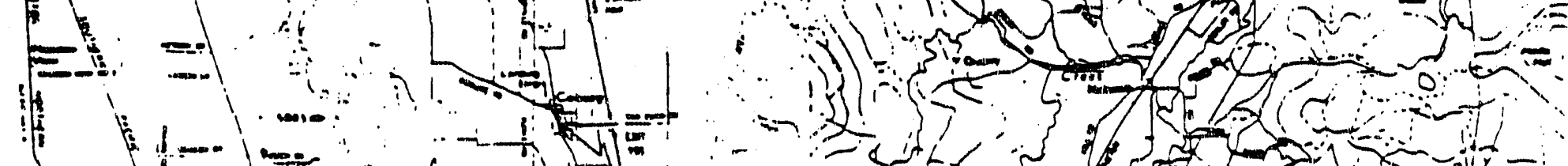

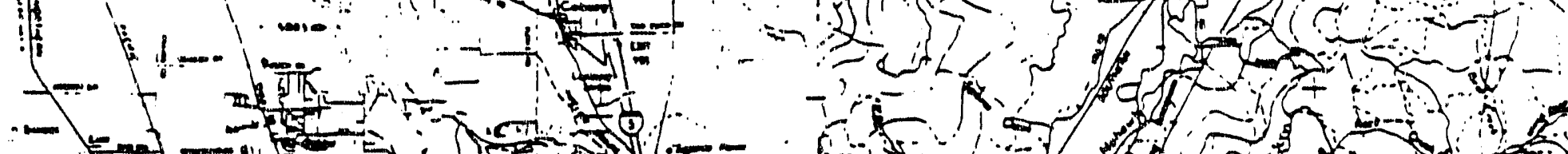
$=1-10$

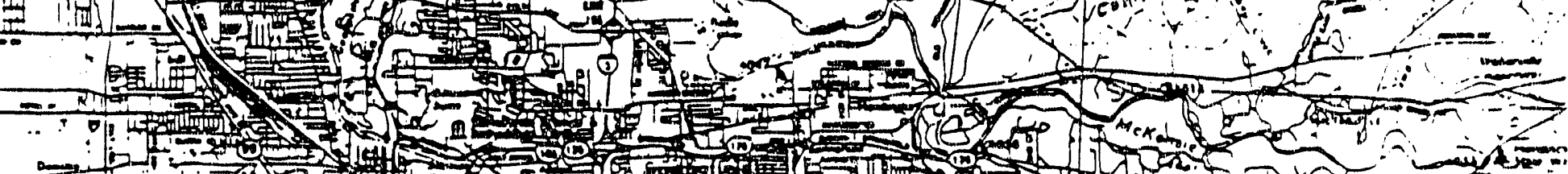

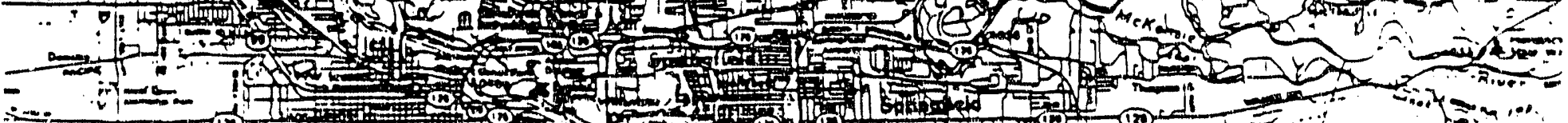

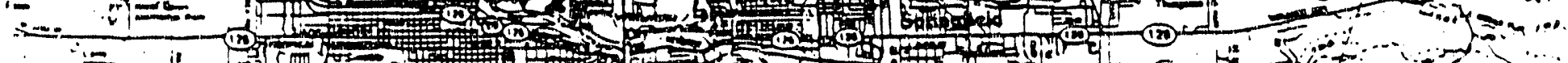

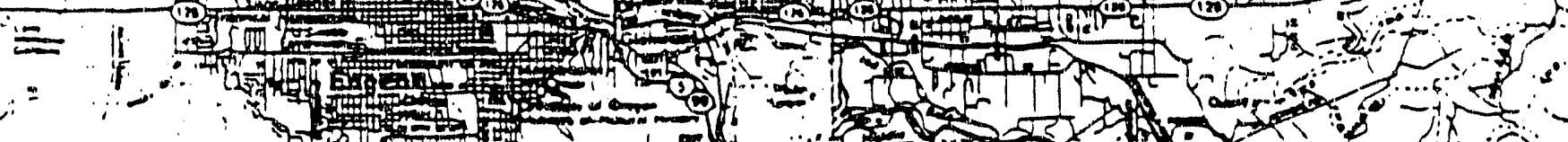

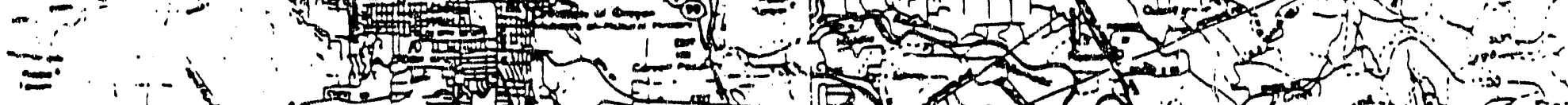

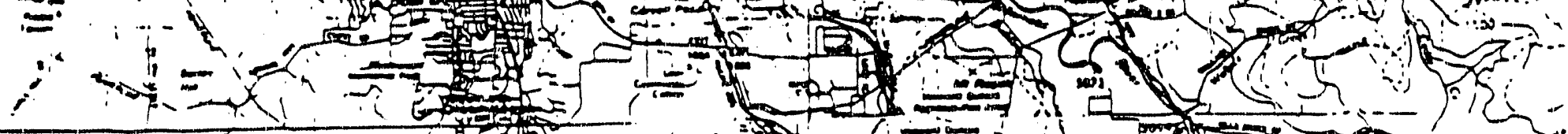

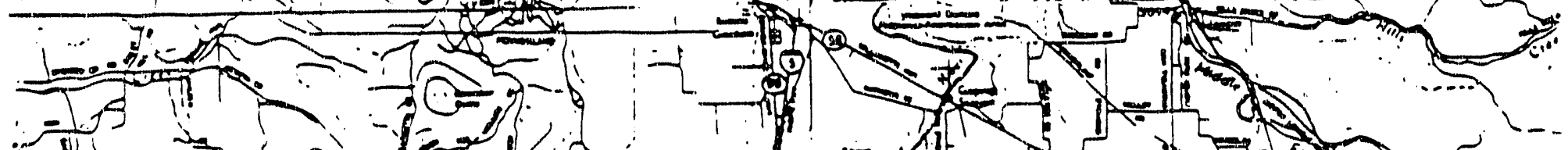
-II

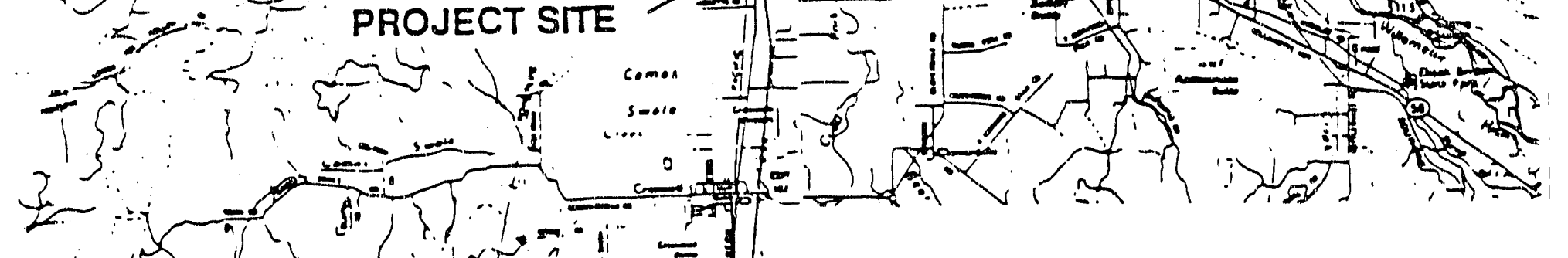
(1)

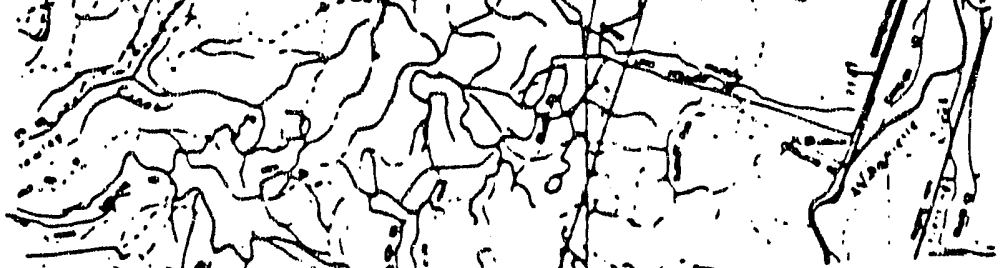
in 皮,

\section{State of Oregon}

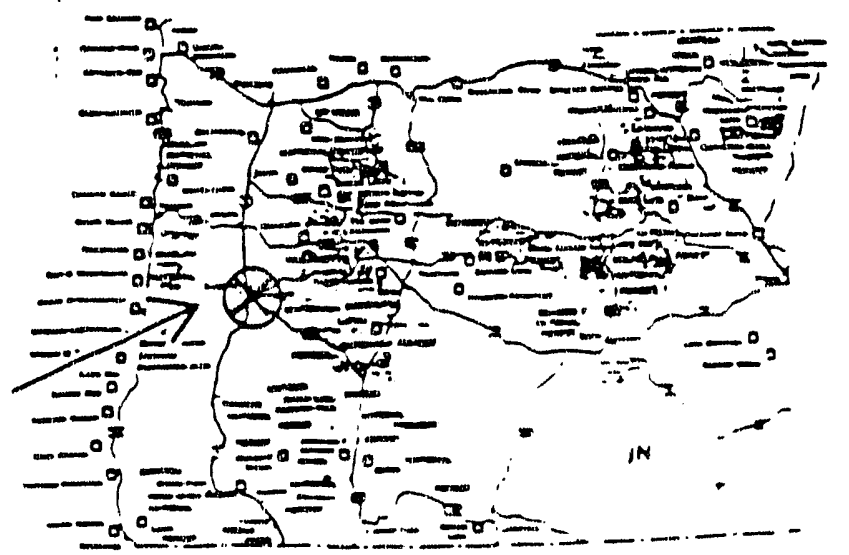




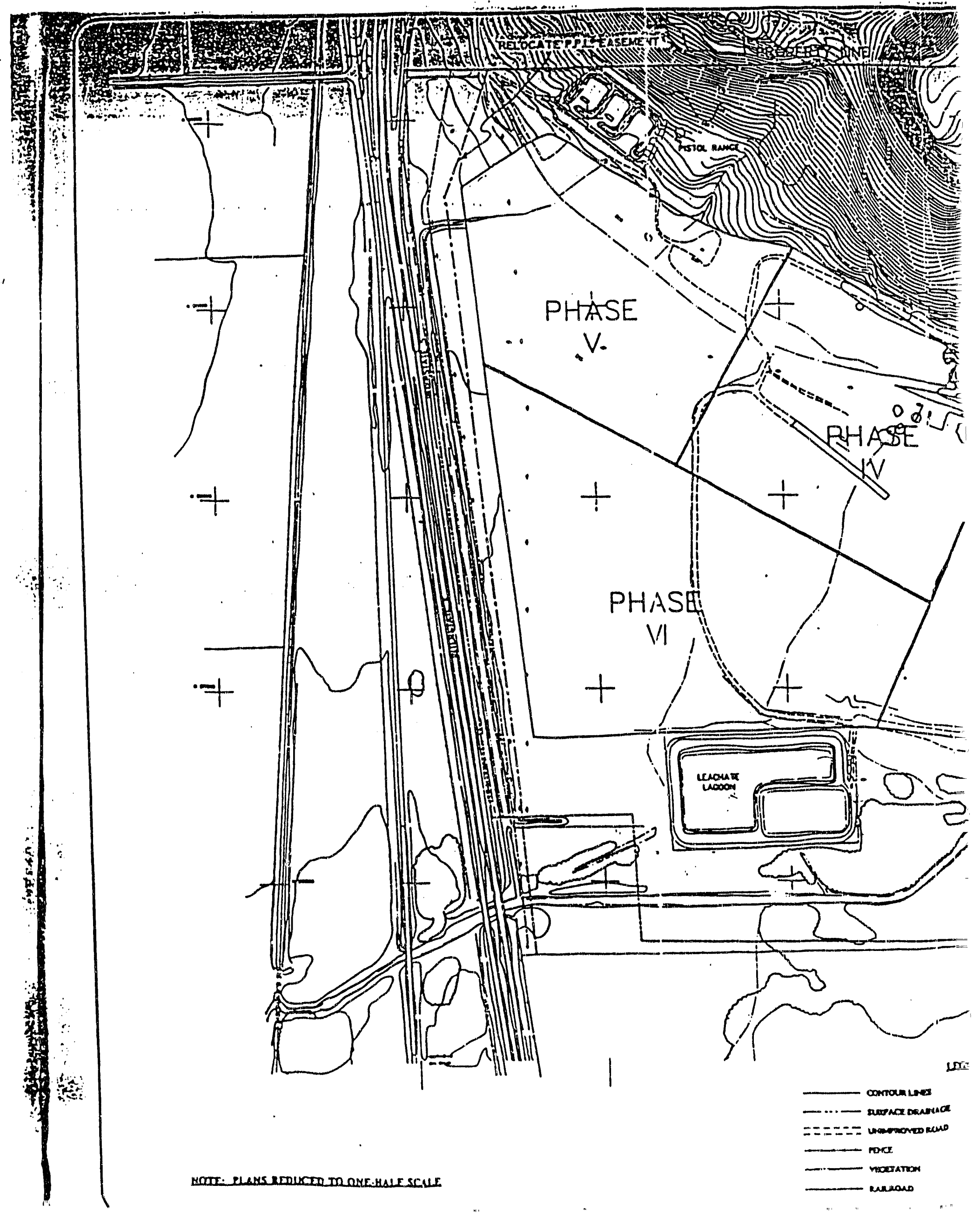




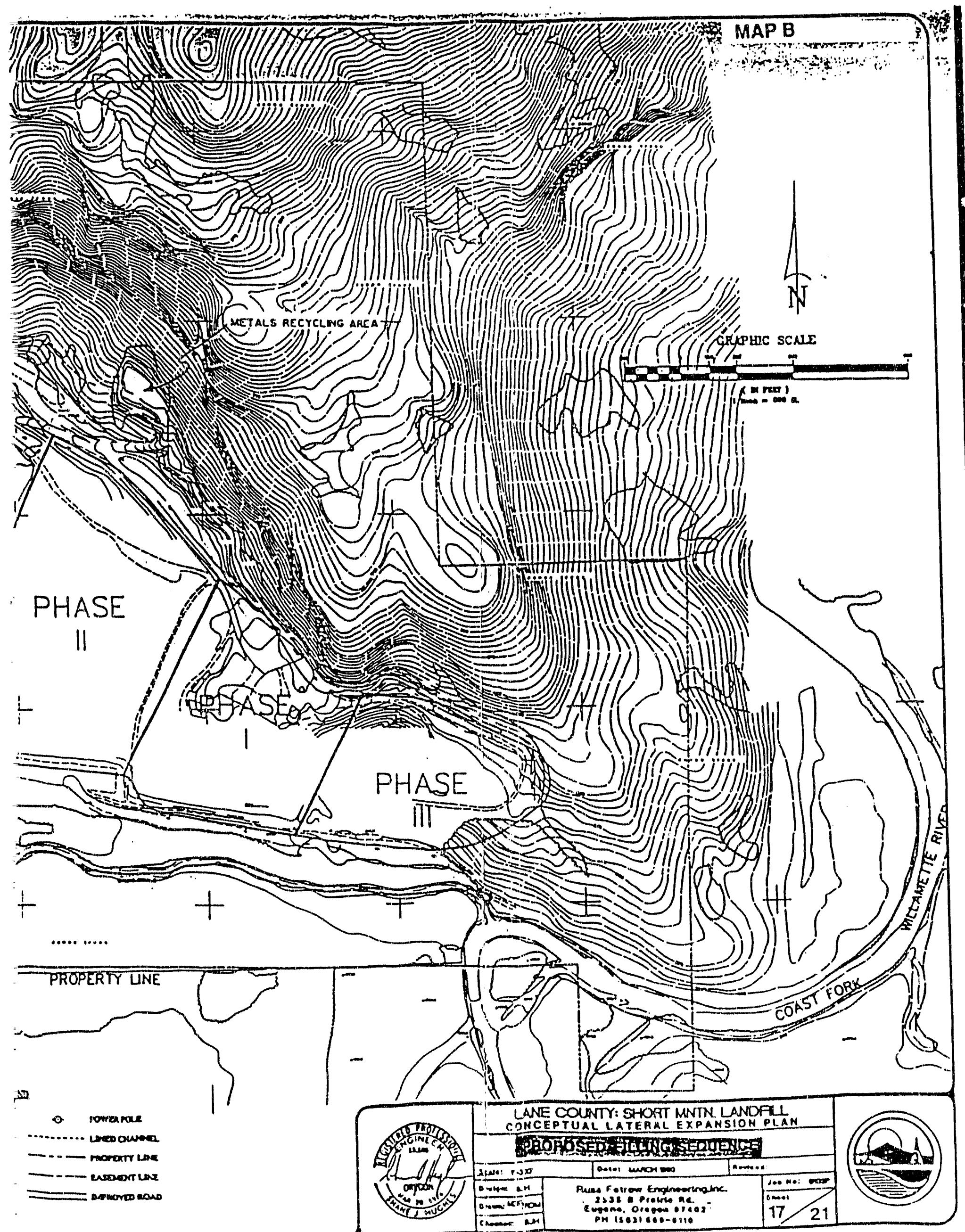




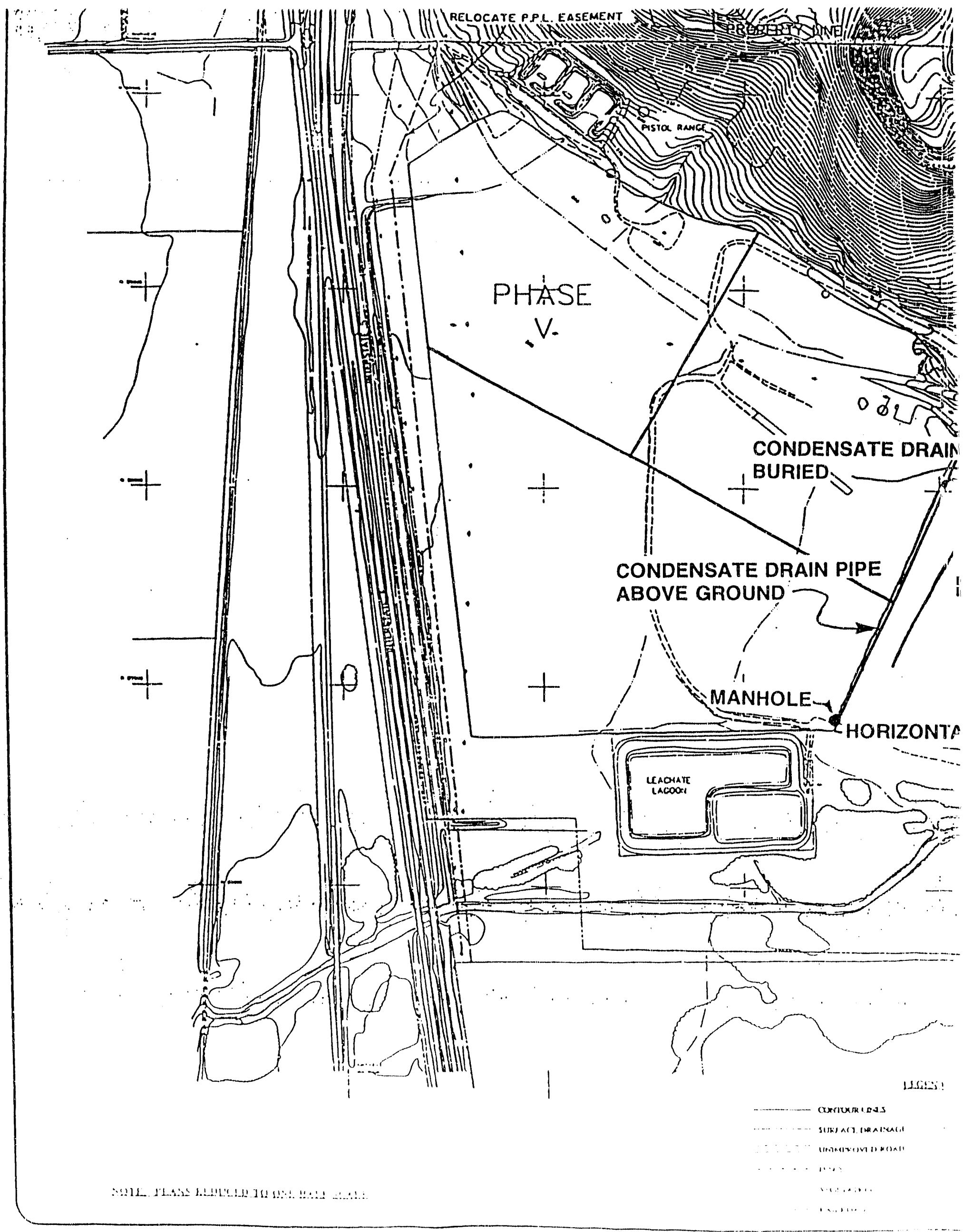




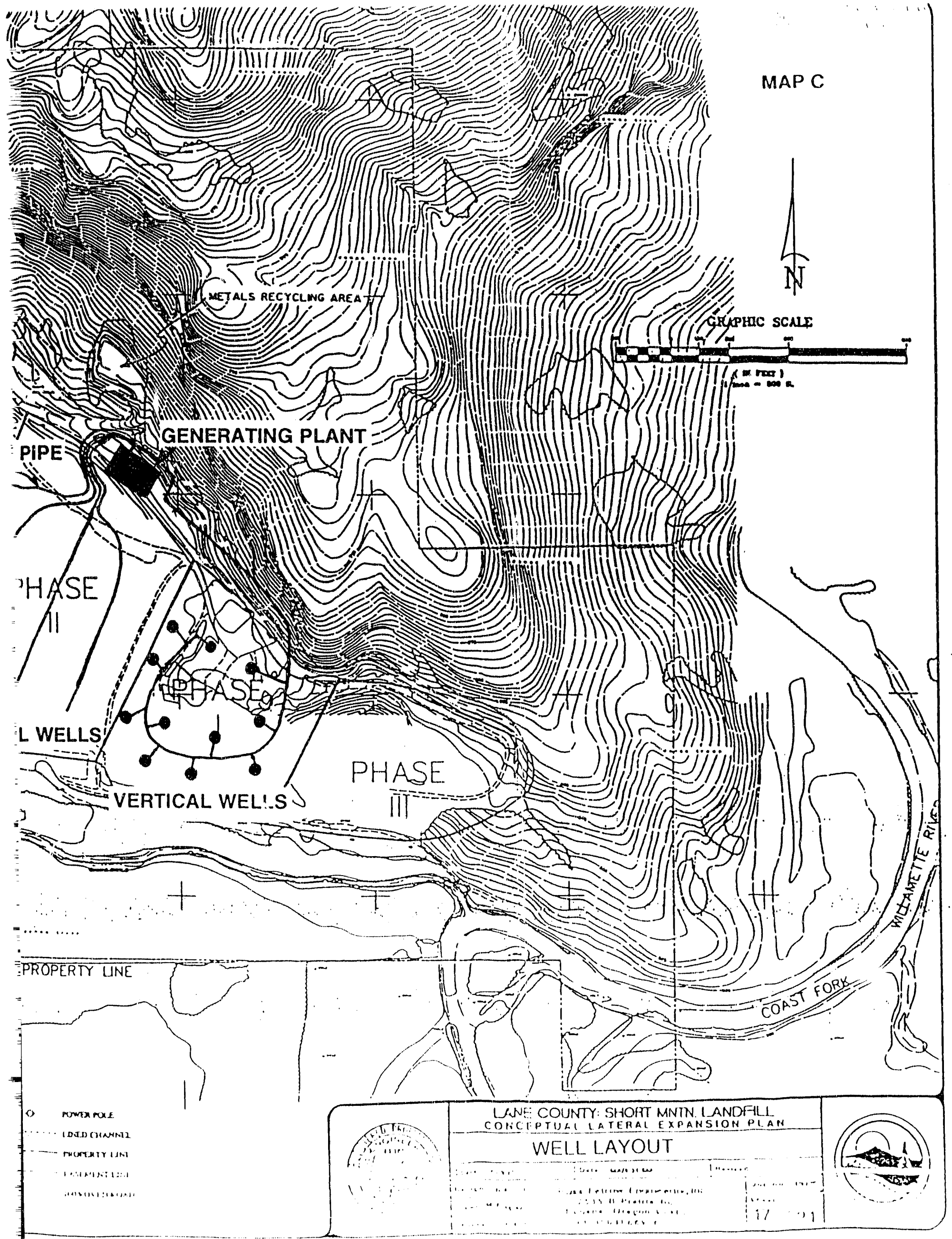




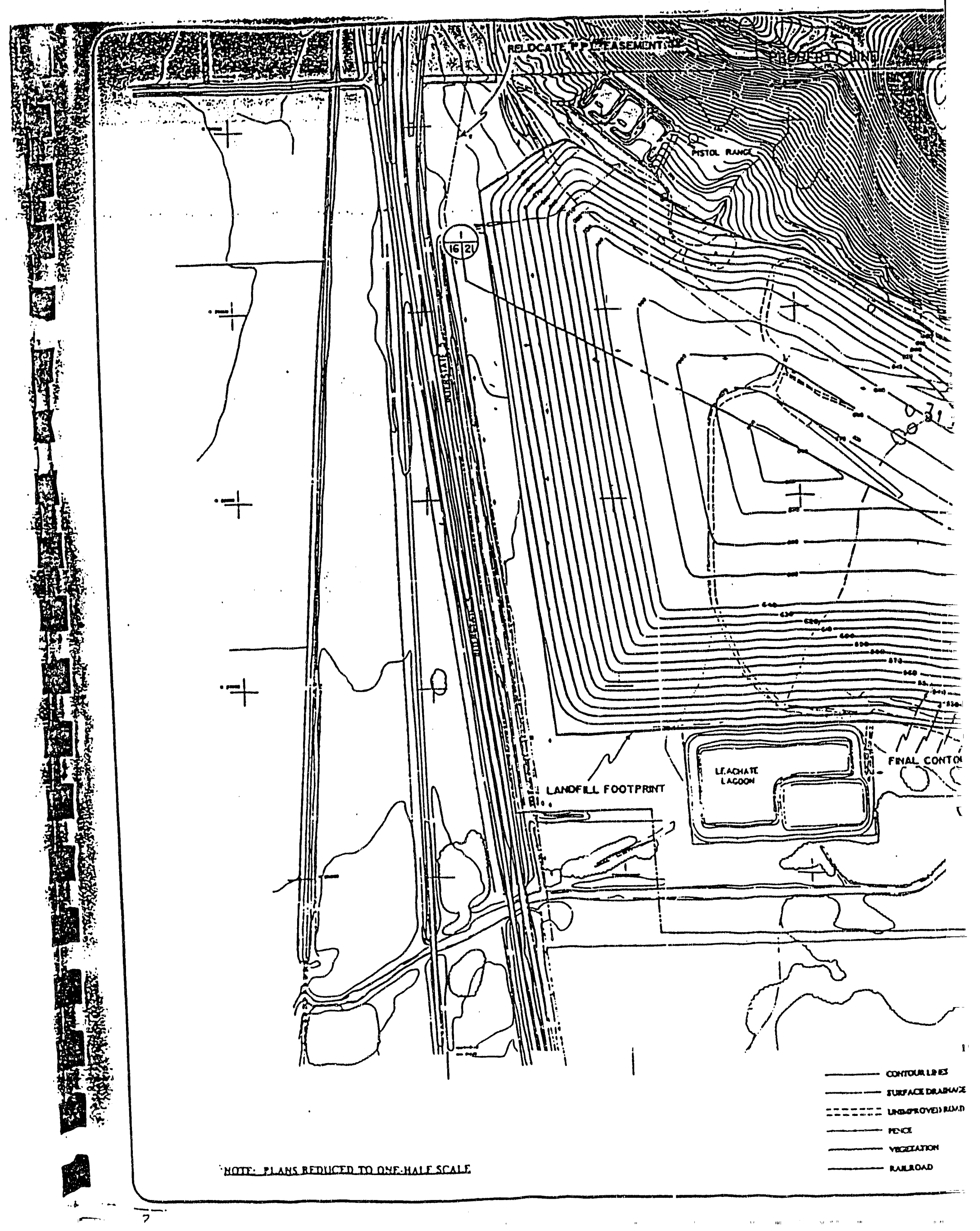




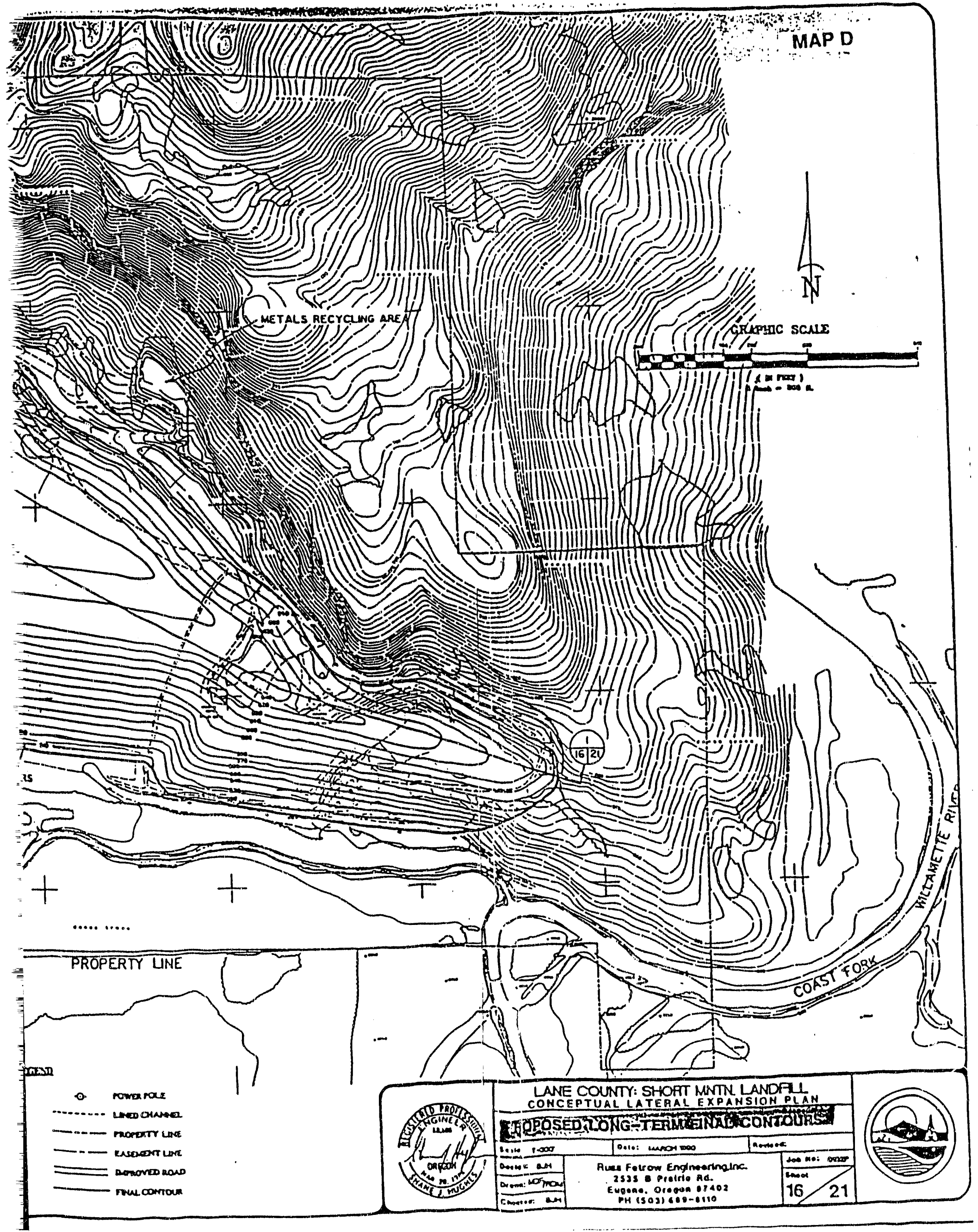




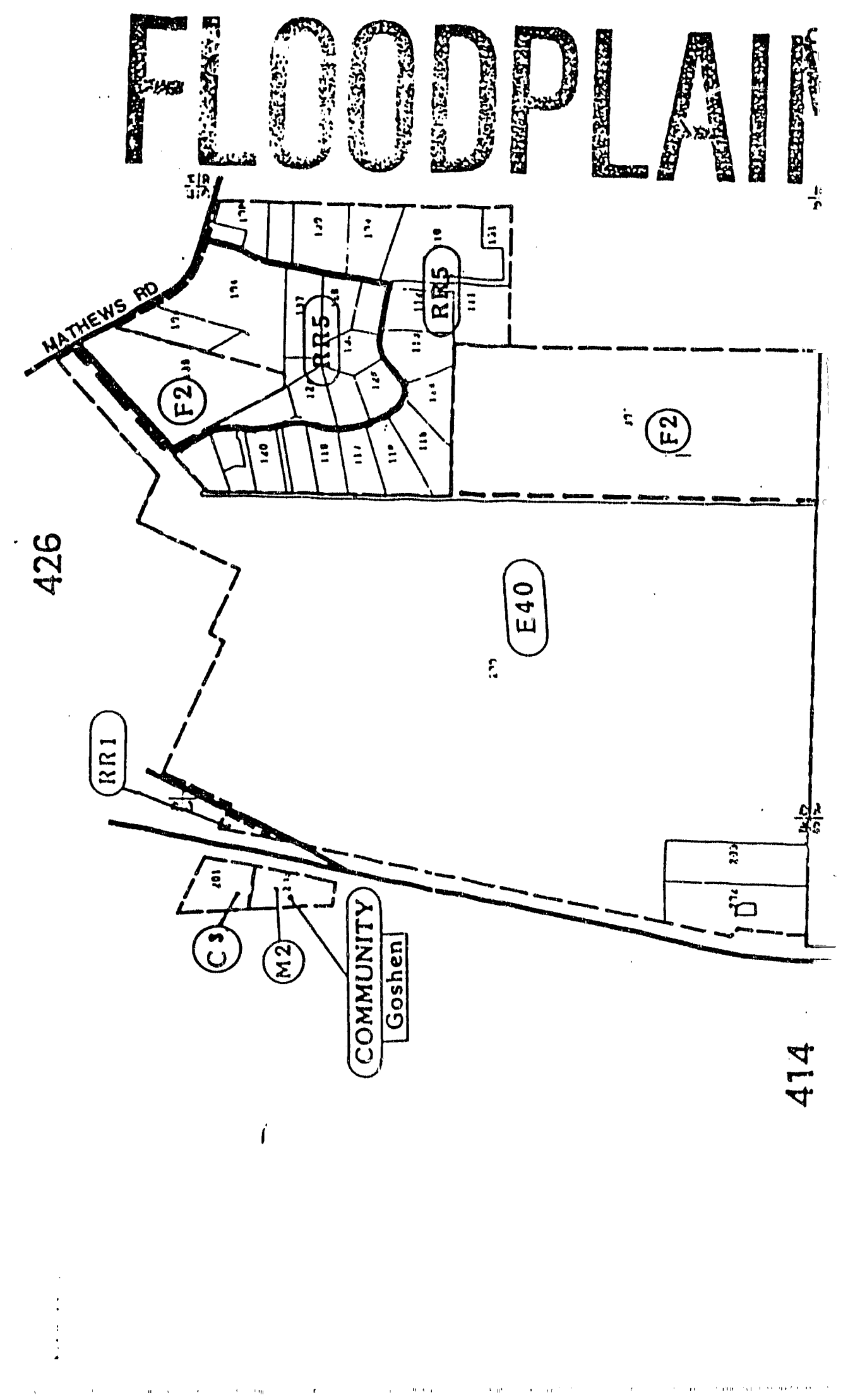


MAP E-1
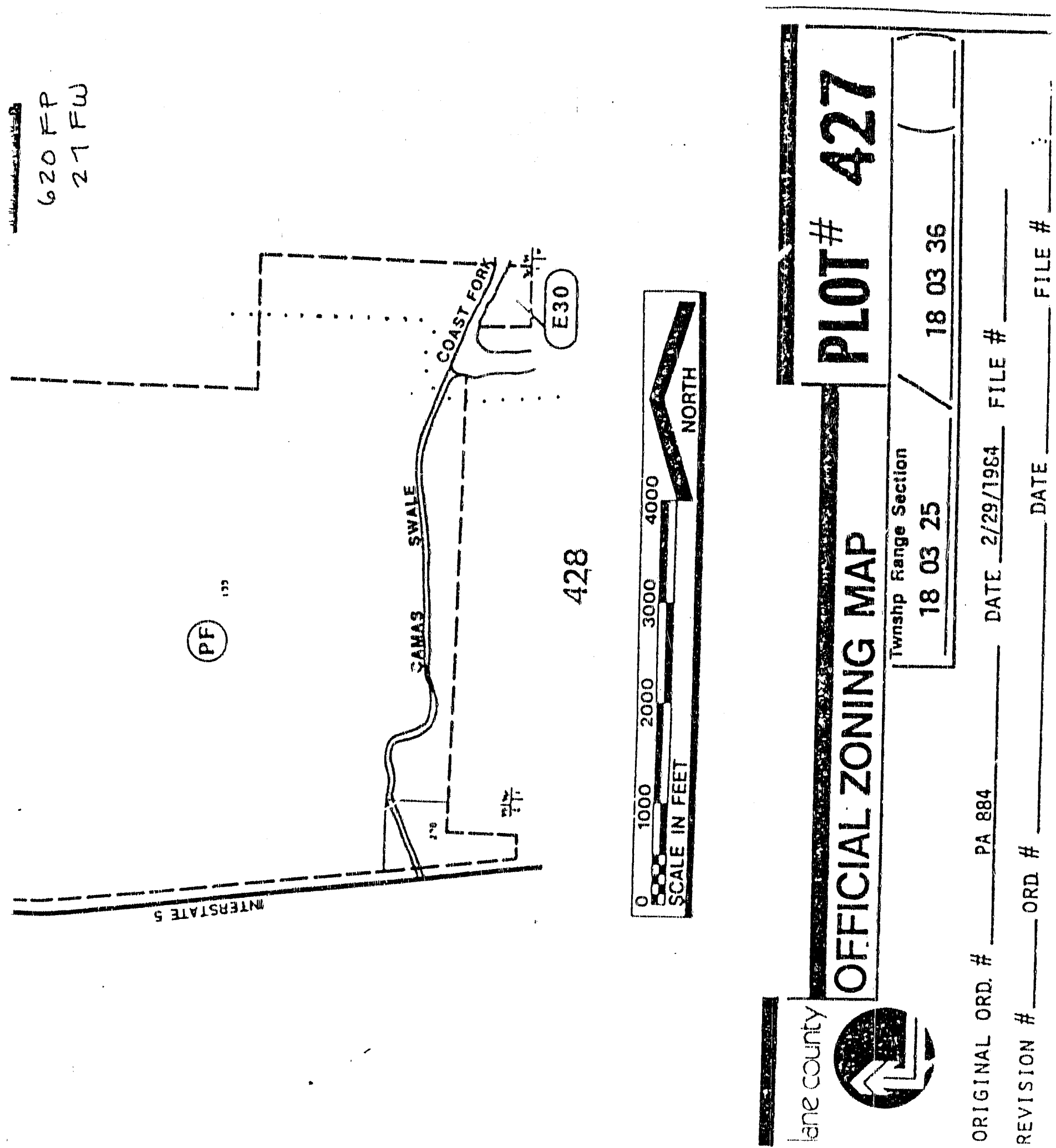


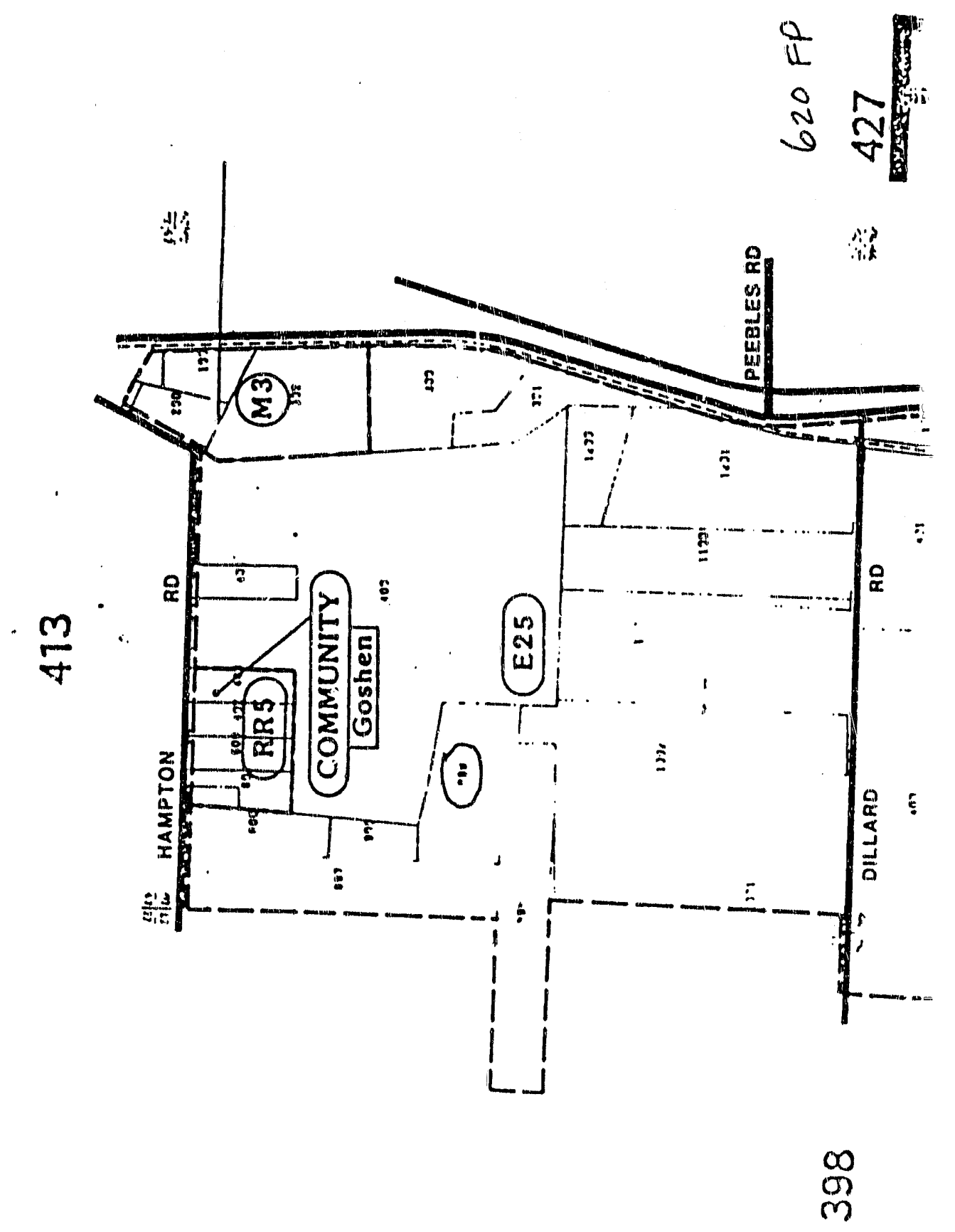


MAP E-2

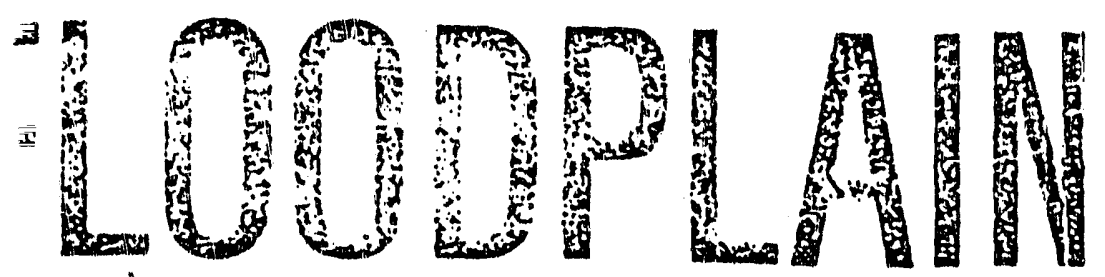

:-
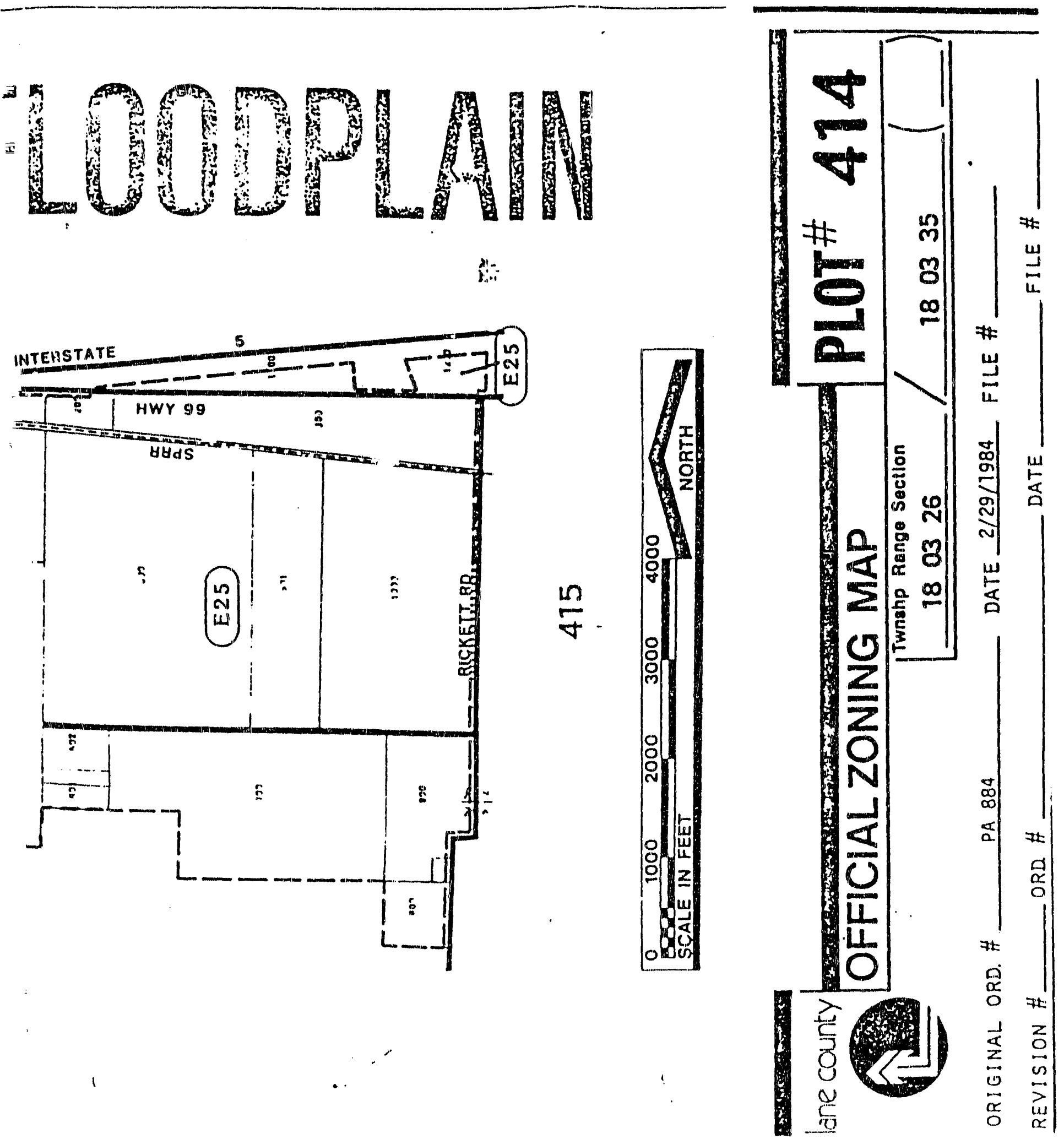


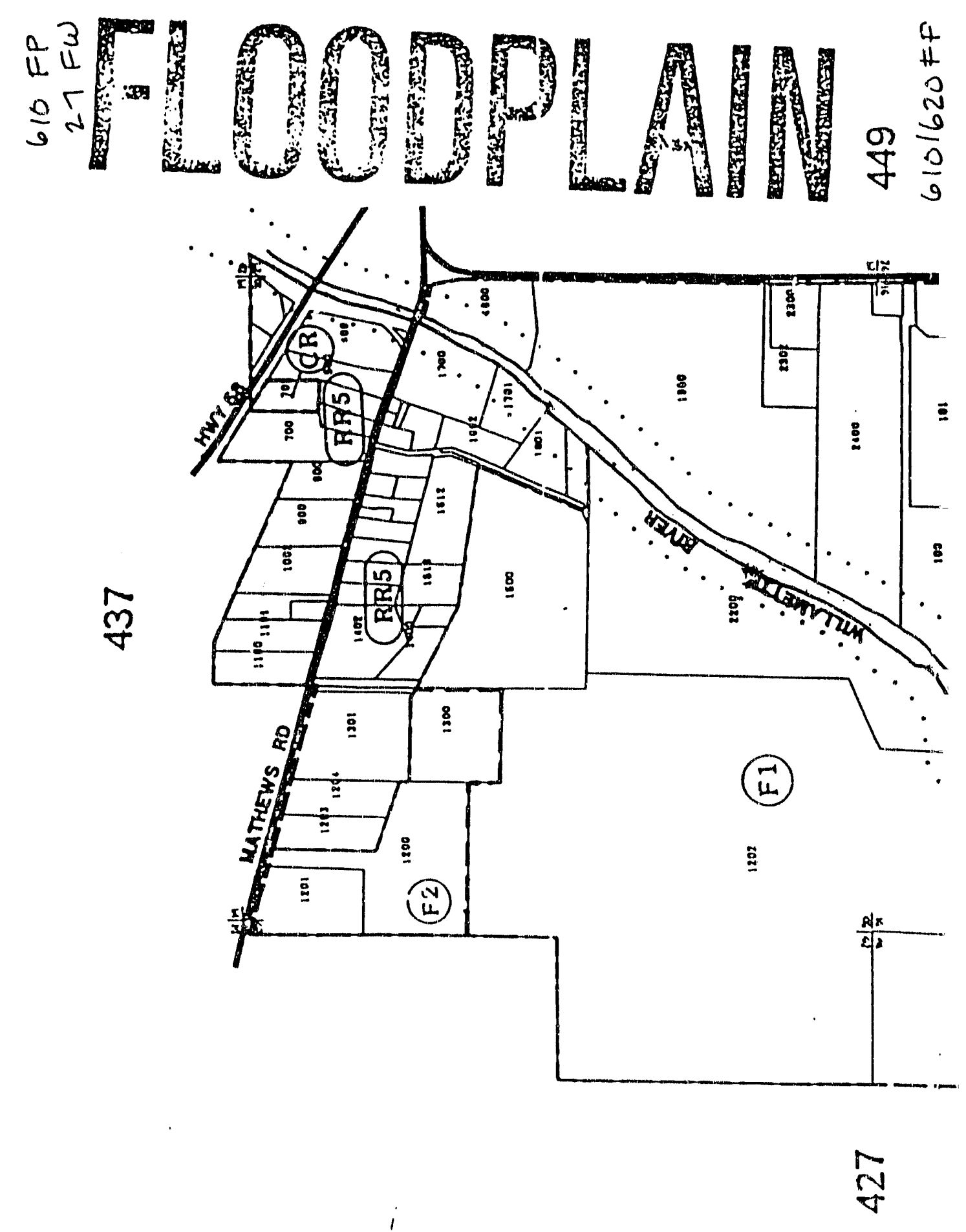


MAPE-3

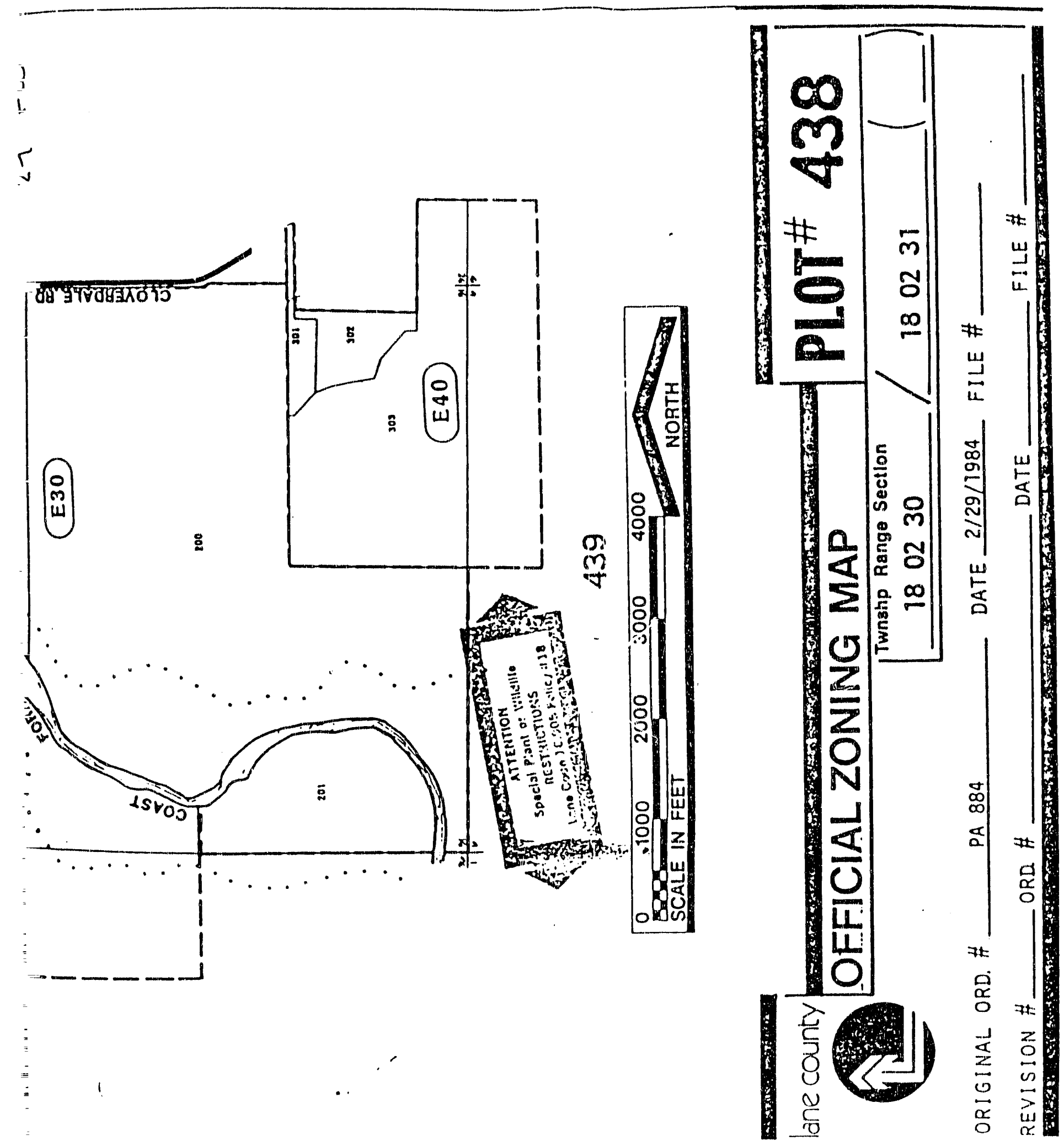




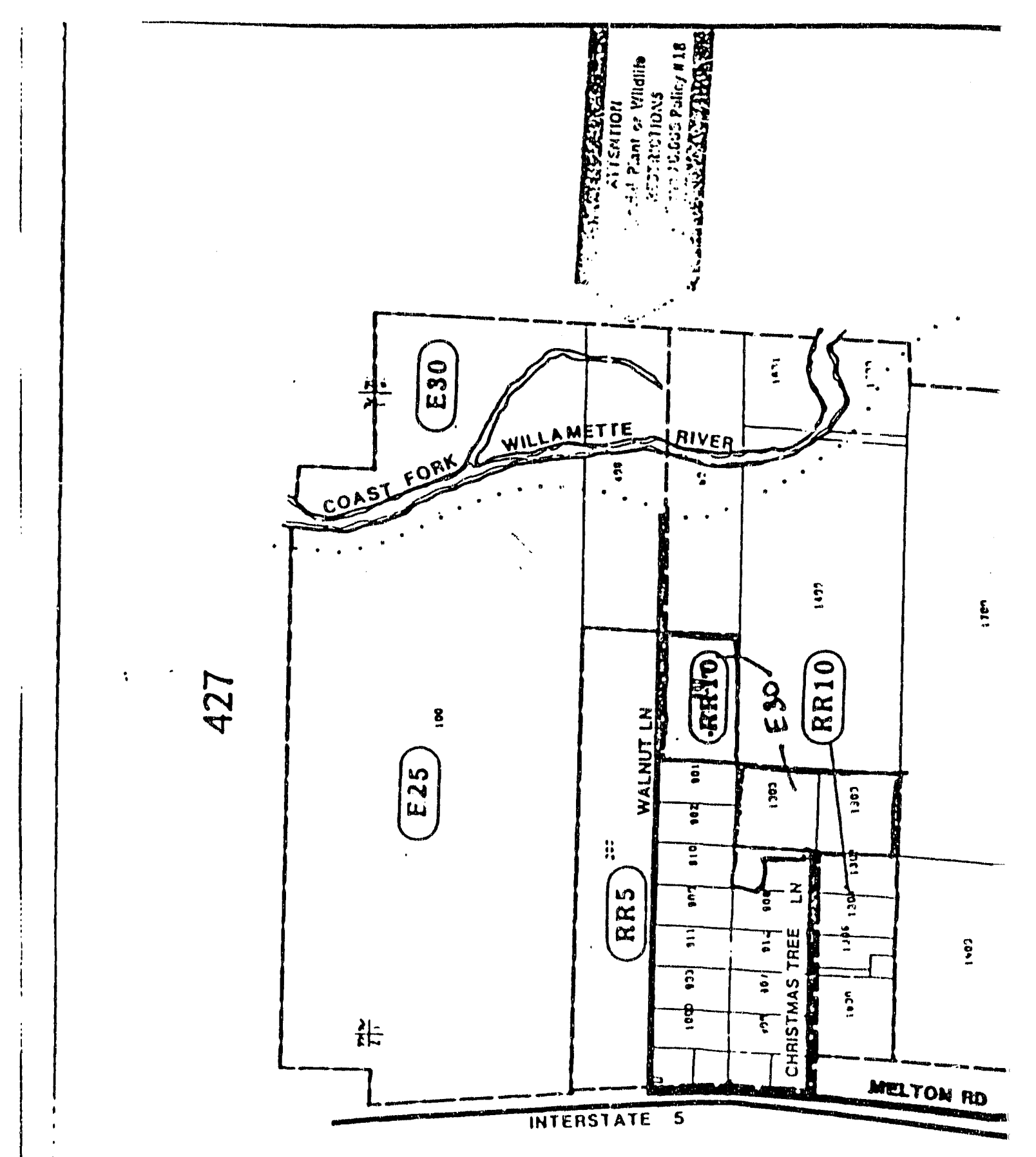




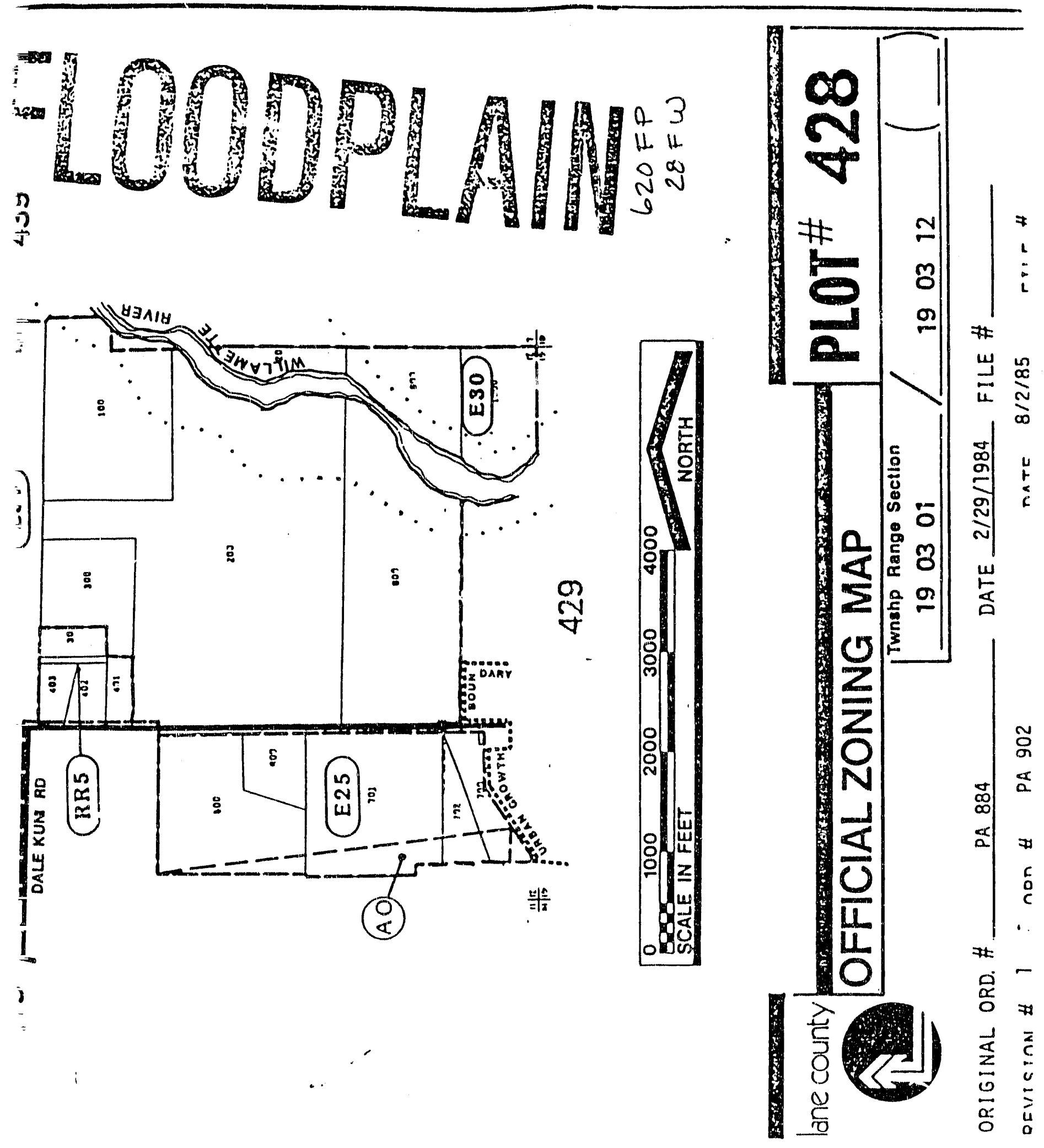



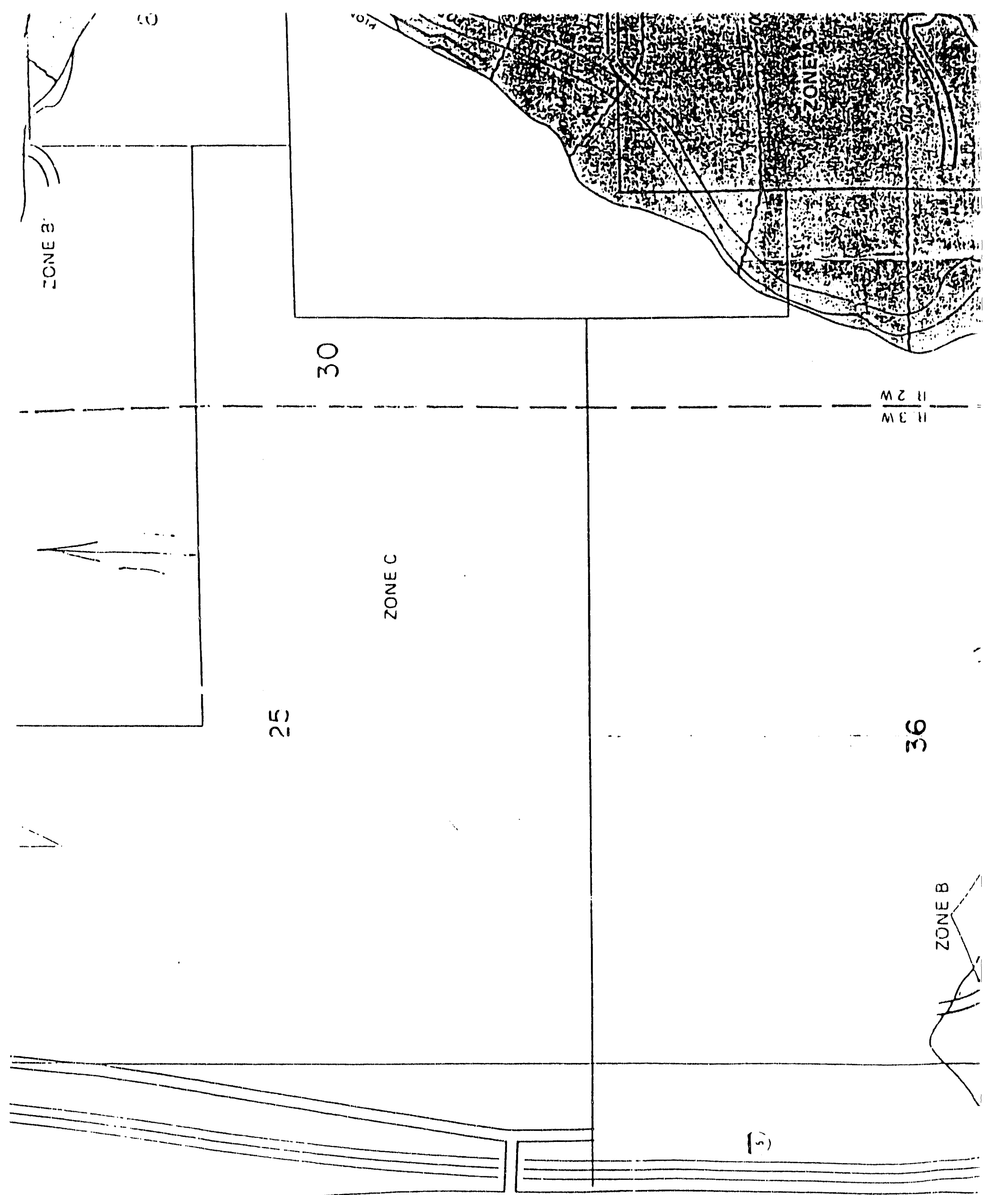

(i)

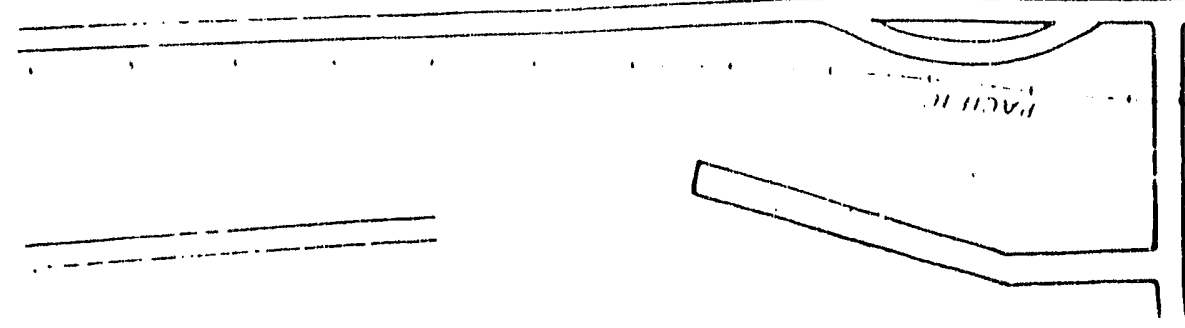

(3)

ist viluser 


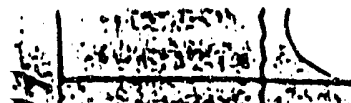

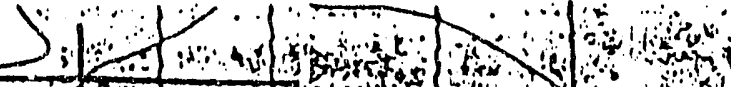

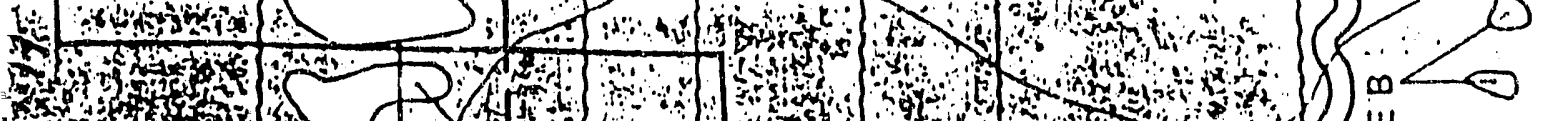

(1) P

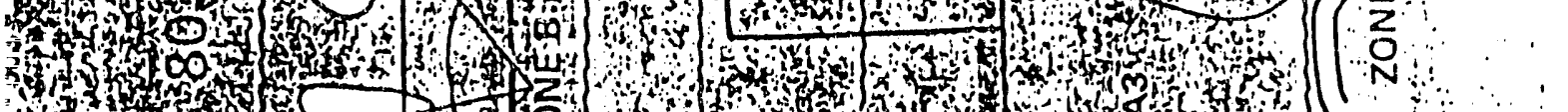

1.

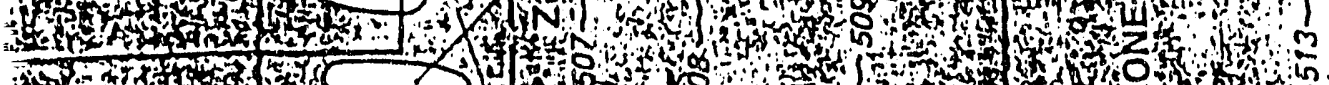
(1)

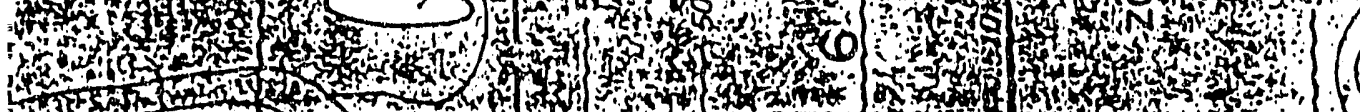

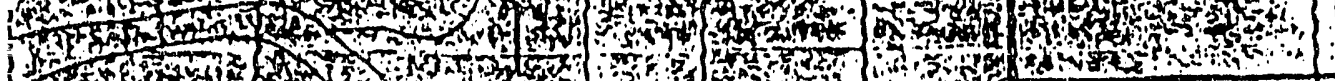

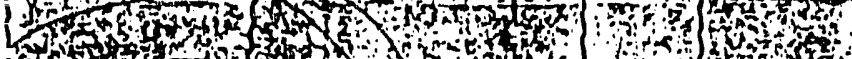

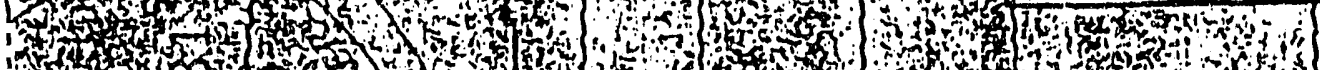

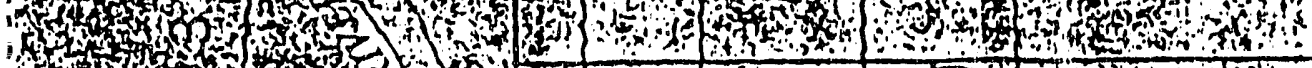

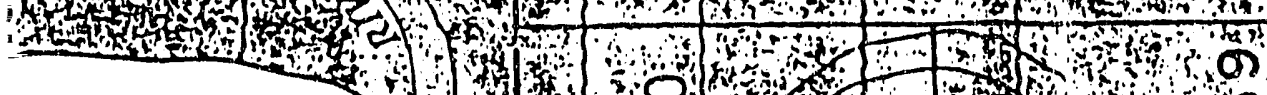
M Zy

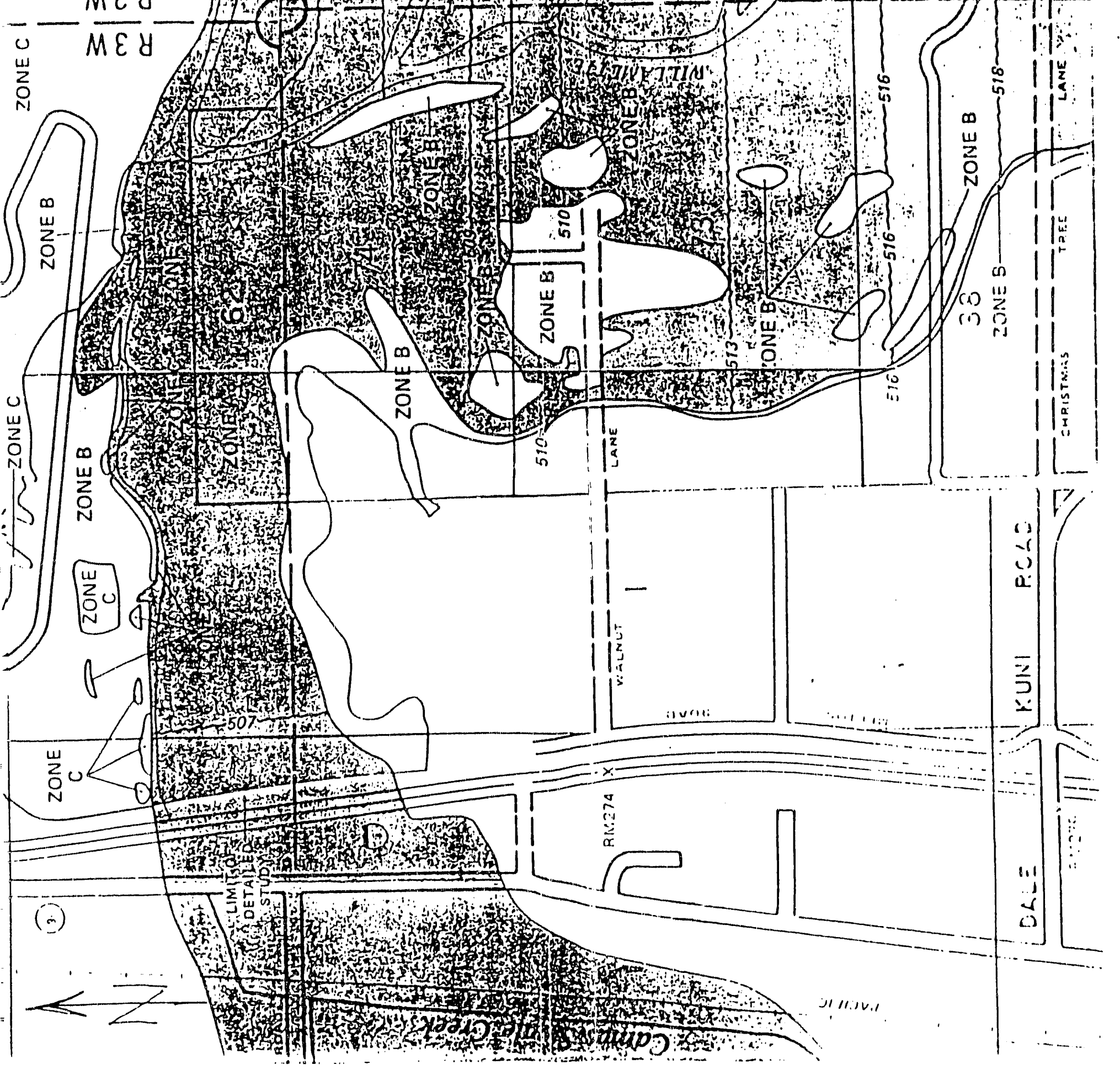




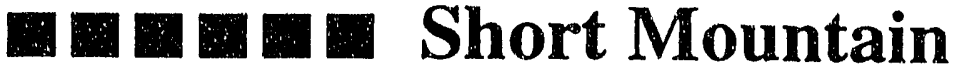

\section{Landfill Gas Project}

Clean Water Act

\section{Compliance}

Prepared for

U.S. Department of Energy Bonneville PowerAdministration

February 10, 1992 


\section{SHORT MOUNTAIN LANDFILL GAS PROJECT \\ CLEAN WATER ACT COMPLIANCE}

\subsection{BACKGROUND}

The Bonneville Power Administration (BPA) has received a Billing Credit proposal from the Emerald People's Utility District (Emerald PUD) for power produced at the proposed Short Mountain Landfill Gas Project located in Lane County, newr the town of Creswell. An Environmental Assessment (EA) was prepared on the project and made available for a 30-day public review period which ended on January 7, 1992. BPA is now in the process of incorporating cormments into the EA, and is preparing a Finding of No Significant Impact.

An issue of concern that was raised during the public comment period is whether the construction of the condensate drain pipe complies with Oregon's Fill-Removal Program and Section 404 of the Clean Water Act. BPA has contracted with Woodward-Clyde Consultants to complete a wetland delineation of the condensate drain pipe to determine if there are any project related impacts to wetlands, and to consult with the Oregon Division of State Lands (DSL) and the U.S. Army Corps of Engineers (Corps) to determine what steps must be taken for the project to comply with Oregon's Fill-Removal Program and Section 404 of the Clean Water Act. 


\subsection{SUMMARY}

On February 6, 1992, a wetland delineation was conducted at the landfill site along the newly constructed condensate pipeline. Soils, hydrology, and vegetation were investigated consistent with the 1989 Federal Wetland Delineation Manual, which is accepted by DSL, and the 1987 Wetlands Manual, which is adopted ty the Corps. The condensate pipeline does not cross wetlands regulated by DSL or the Corps.

\subsection{SITE DESCRIPTION}

The condensate pipe carries condensate from the generating plant to a manhole at the base of the landfiul. The condensate is then discharged into an existing pipeline along with other landfill leachate into the leachate ponc. Condensate is generated from several gas transmission lines which are located in the existing Phase 1 and Phase 2 areas of the landfill (Figure 1).

The condensate pipeline is buried from the generating plant to the northwest edge of the sealed landfill. It crosses under a new road and through the sealed landfill at approximately the same depth as the horizontal gas transmission wells. The condensate pipe closely follows the same course as one of the horizontal wells, until it diverges and surfaces at the side of the landfill near an old road now covered by the capping of phase 2 (see aerial photo and Figure 1). 
From here, the condensate pipe then follows the side of the landfill, about half the distance between the toe and the top. The condensate pipe remains on the surface for the entire length of the landfill until it connects to the manhole.

\subsection{Final Construction Plans}

As-built drawings of the final construction have not yet been produced. Alan Zelenka from the Emerald PUD was able to field-verify the upper location of the buried portions of the condensate pipe, as well as to confirm that the connection to the manhole for the condensate pipe completed the new construction work associated with the condensate pipeline. Figure 1 shows the final construction alignment plan of the condensate pipe drawn from field observation and comments by Alan Zelenka (Alar Zilenka, personal comnunication, February 6, 1992).

\subsection{Delineation of Wetland Boundary}

The area along the condensate pipe was examined for wetland indicators. Data did not show positive wetland indicators from Site \#1, on the surface of the landfill where the pipeline crosses below ground, and Site \#3, along the side of the landfill where the pipe rests on the surface. Site \#3 did contain some wet spots along the side of the landfill. Even though the soils showed signs of saturation, there were no wetland plants noted at this location. Site \#1 was devoid of plants and covered with hay (Figure 2). 
Wetlands were observed near the landfill site, however they were not affected by the condensate pipeline. Data was collected from two locations that indicated the presence of wetlands. Site \#2 is located near the top of the landtill in an area that overlays the old road. Standing pools from 3 inches to 1.5 feet deep were observed in what appeared to be tire track impressions left by heavy machinery used to remove the old road. This area may also have served as a drainage ditch on the uphill side of the old road. Wetlands were also observed but not confirmed along the northwest toe of the landfill. Site \#4, within 30 to 40 feet of the condensate manhole at the southern toe of the landfill, contained indicators of wetlands, including a small tributary that feeds into a culvert crossing the road near the leachate pond (Figure 2).

\subsection{DATA FROM FIELD SURVEY RËSULTS}

\subsection{Soils}

The U.S. Soil Conservation Service Soil Survey for Lane County describes the soil under the landfill as Natroy silıy clay loam (85) and Bashaw clay (8), which are both poorly drained and listed as hydric soils. The Bashaw clay is located closer to Camas swale, with the majority of the landfill located on the Natroy silty clay loam (Figure 3).

The soil types found on the landfill were highly variable. The native soil was mixed with lighter non-hydric soils and sand and gravel. Most of the soil along the side of the landfill, especially the top 0-3 inches, was non-hydric. At Sites \#2 and \#4, mottling was present in the hydric soils, and little or no fill material was found. At the sites that did not contain 
wetlinds, Sites \#1 and \#3, the hydric soil contained mottling. The non-hydric fill material did not contain mottling.

\subsection{Vegetation}

The plant community along the side of the landfill was upland grass and herbs. The vegetation was sprouting with new growth from recent disturbance. The plant community was vigorous and healthy, showing signs of guod growing conditions. Along the side of the landfill at Site \#3, the plant community was dominated by Festuca anundinacea (FACU-), with Boomus carinatus (not listed), Lolium perenne (FACU), and Stellaria media (UPL). Site \#1 had no vegetation present.

The wetland described at Site \#2 contained Mentha pulegioides (OBL), Lythrum hyssopifolium (OBL), Festuca arundinacea (FACU-), Lolium perenne (FACU) and Callitriche sp. (OBL). Various forms of algae were growing in the water. Wetland Site \#4 was dominated by Juncus patens (FACW), Dipsacus sylvestris (FAC?), Eleccharis palustris (OBL), with yuncus ensifolius (FACW), Salix piperi (FACW), and Typha latifolia (OBL). Algae also grew in the pool. Vegetation at all the sites was disturbed.

\subsection{Hydrology}

Some pooling of water was noted on the landfill near the condensate pipeline crossing. This pool was located at the base of a gravel pile near the old road (Figure 2). Ponding and saturated soils were also observed at Site \#2. On the landfill where the pipeline is buried. 
some saturation was evident in small puddles. The last rainfall occurred five to six days prior to the field investigation.

Along the side of the landfill where the condensate pipeline lies, the soil was not saturated, however some small areas were sligitly wet. One of these areas, Site \#3, was taken to represent the wettest example on the side of the landfill. Here, the first six inches of the soil was saturated, but from six to ten inches the soil was not saturated. Thus, drainage is good from the side of the landfill down toward the toe.

Site \#4 contained a small rivulet (about 0.5 cubic feet per second) flowing from along the side of the landfill. The water then crossed the road through several culverts and entered a channel of flowing water between the side of the leachate pond and the road. A soil pit dug at Site \#4 showed pooling at 4 " within 30 seconds. Drainage through the clay soil was very slow.

\subsection{CONCLUSION}

The condensate pipeline does not cross wetlands which are regulated by DSL or the Corps. Although the condensate pipe does not cross wetlands, wellands were observed near the existing landfill. No project related impacts were noted that affect these wetlands and as such it is not necessary to consult with the DSL or the Corps at this time. 


\subsection{LIMITATIONS}

This review was limited to the condensate pipeline and features directly related to the newly constructed power project. Since wetlands were observed near the landfill site, any proposed future modifications to the power project should consider wetland impacts and may require coordination with DSL and the Corps. The landfill was not evaluated for past or potential future impacts to wetlands. 


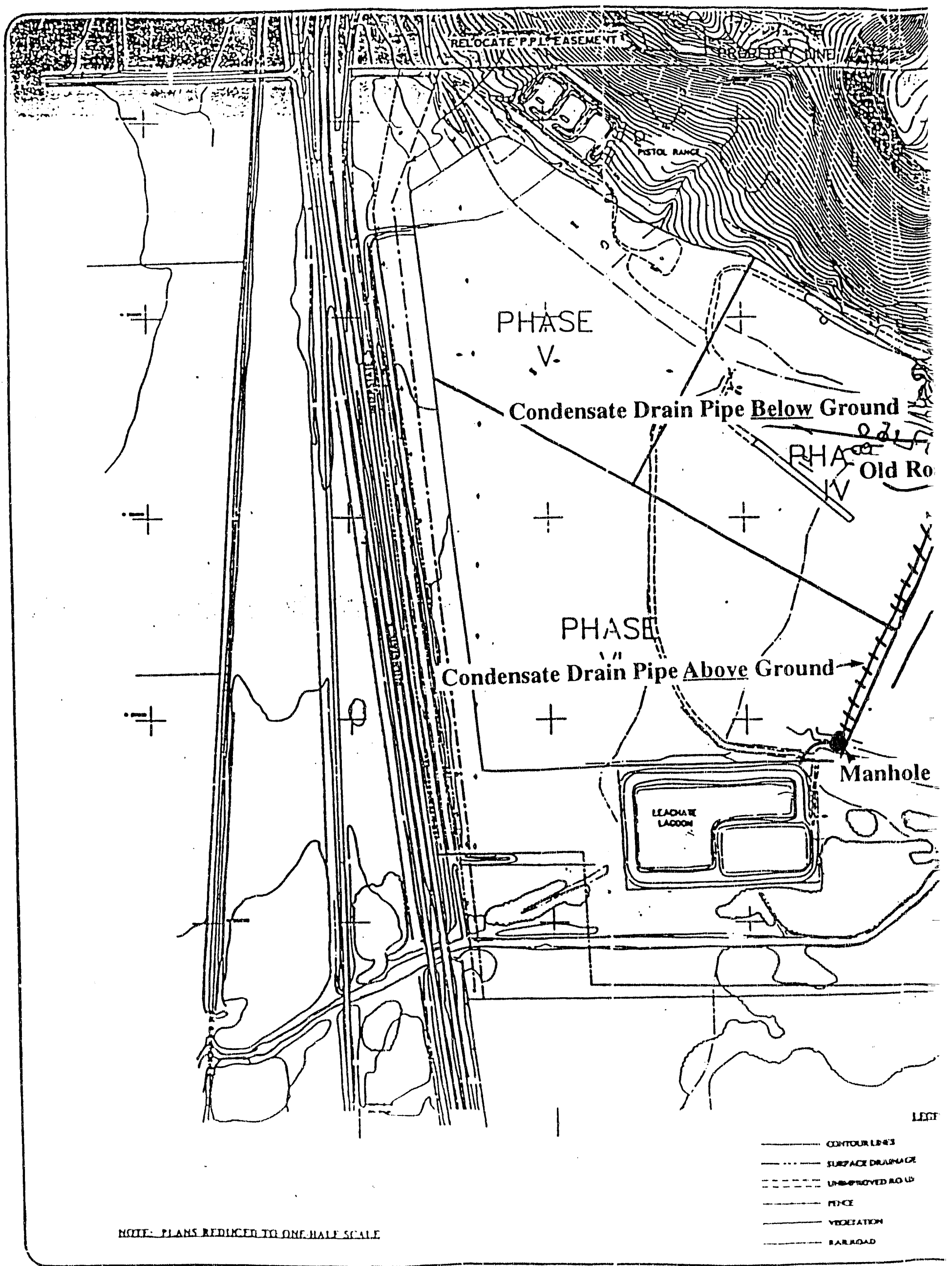




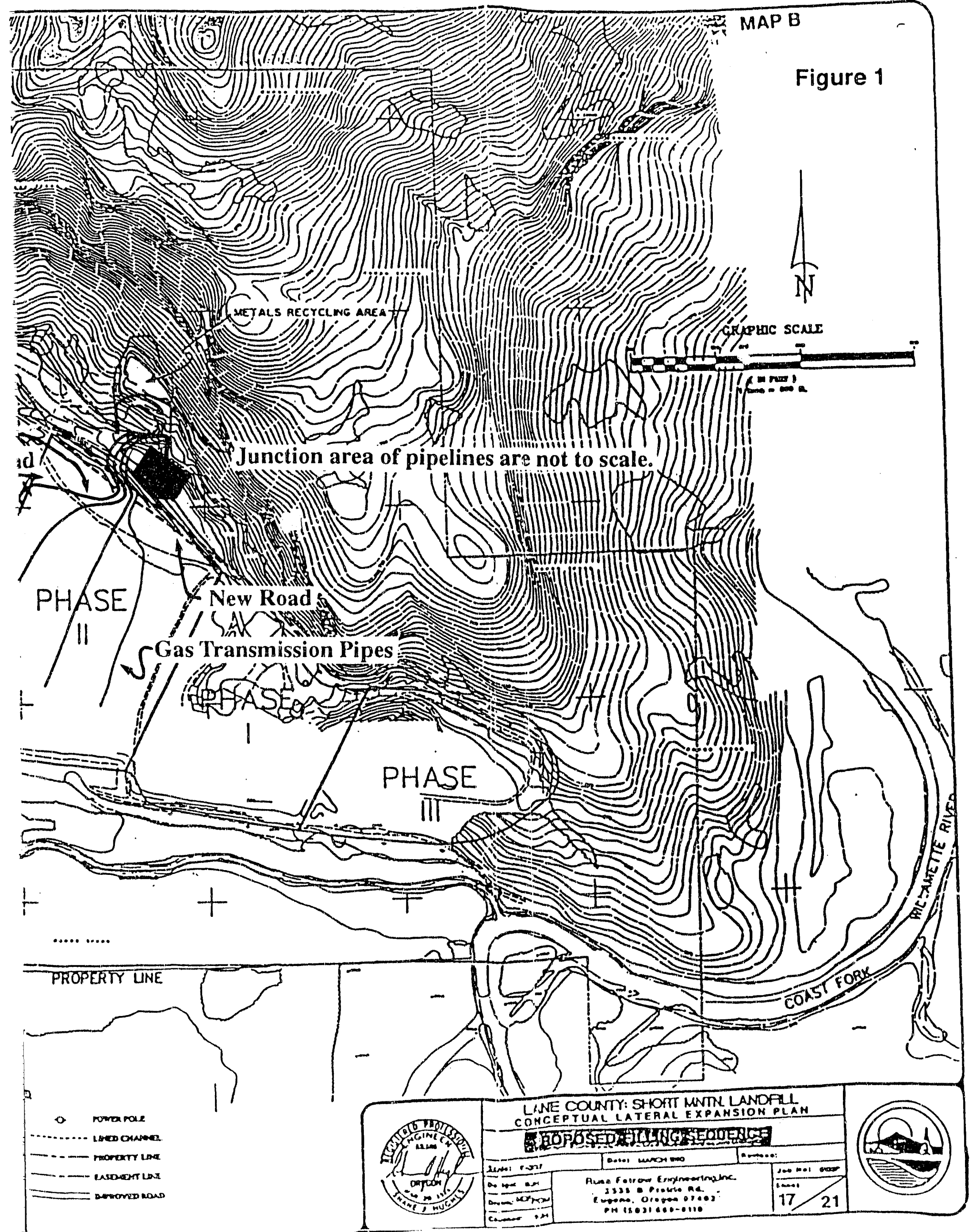




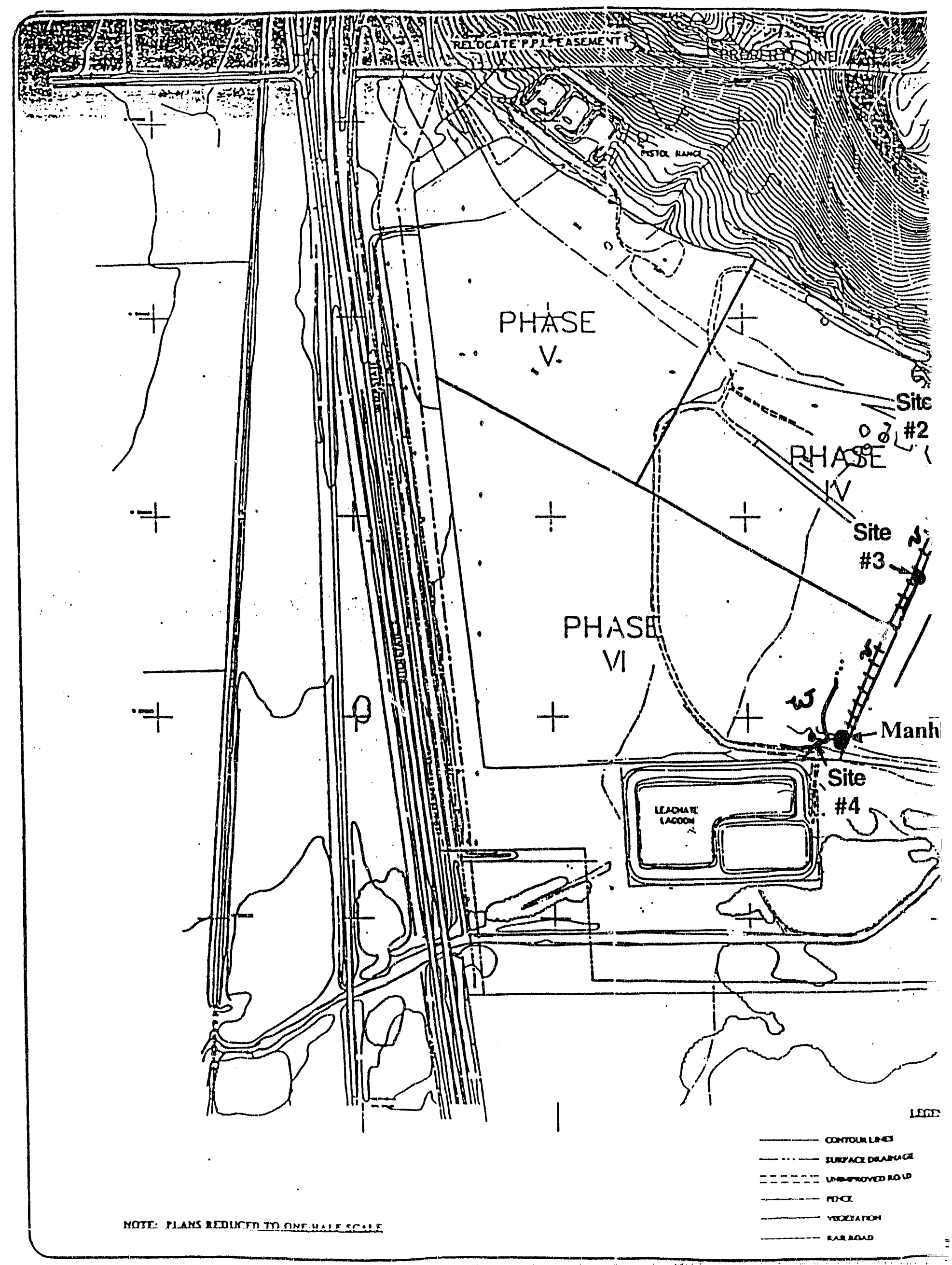




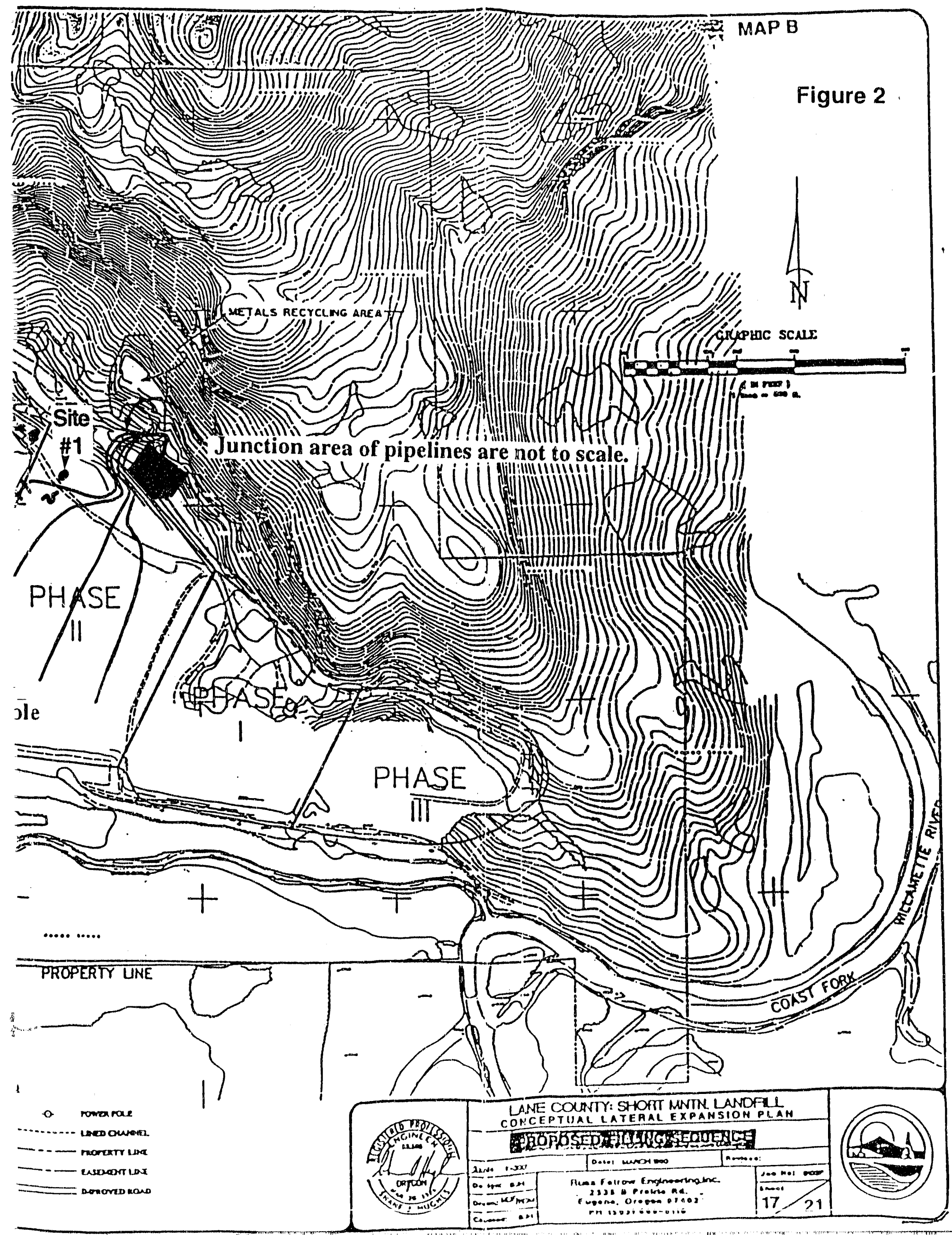




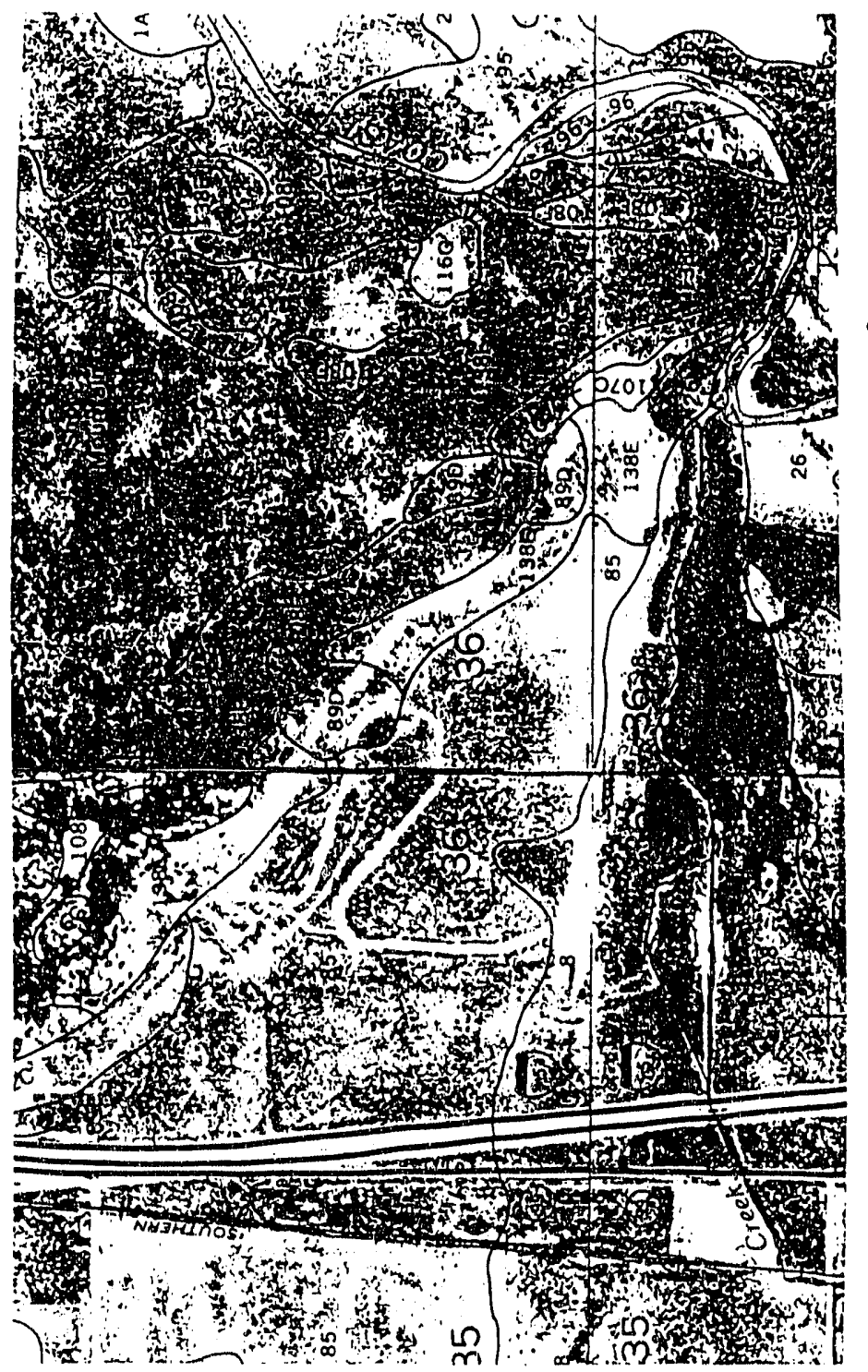




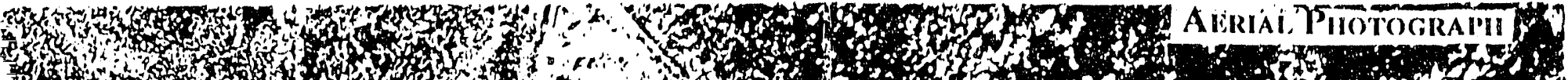

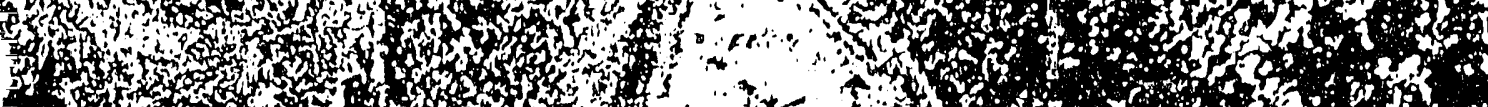

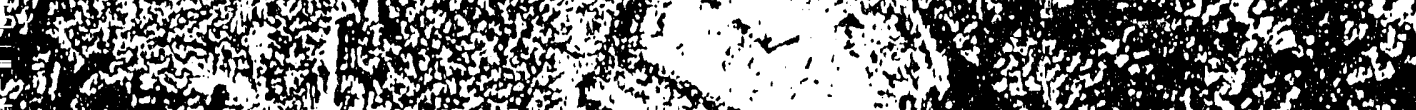

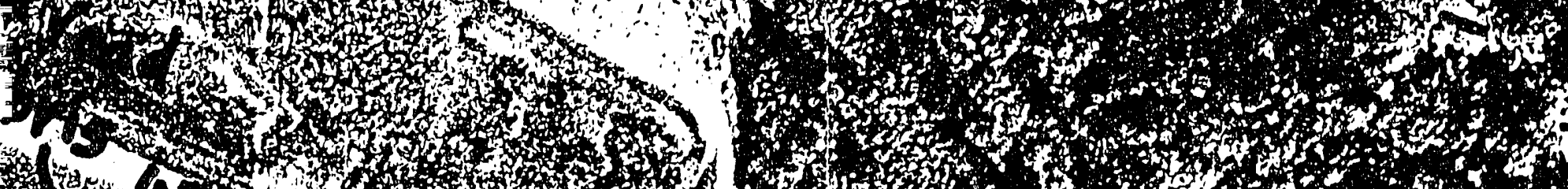

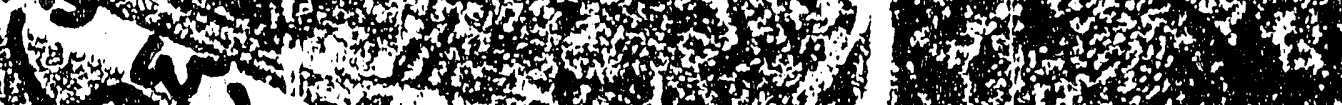

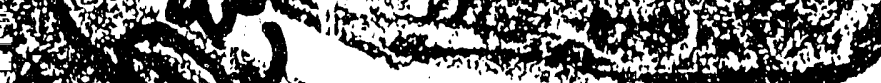

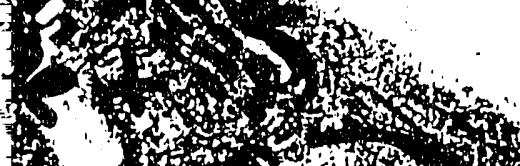

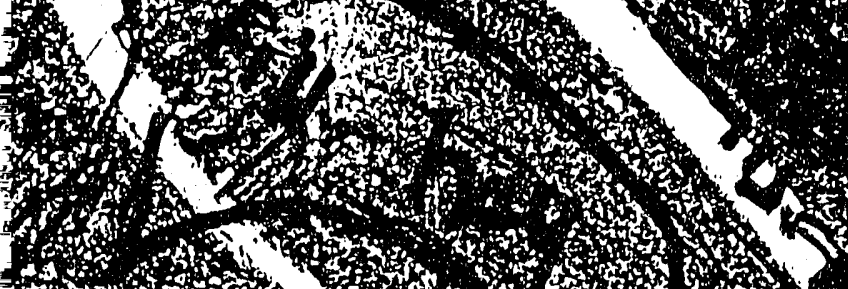
3.

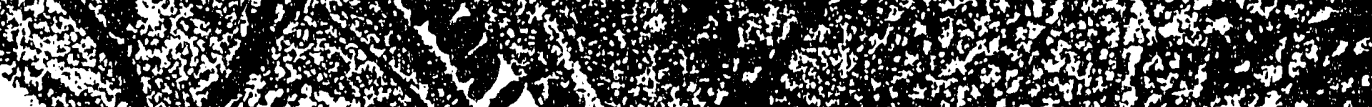

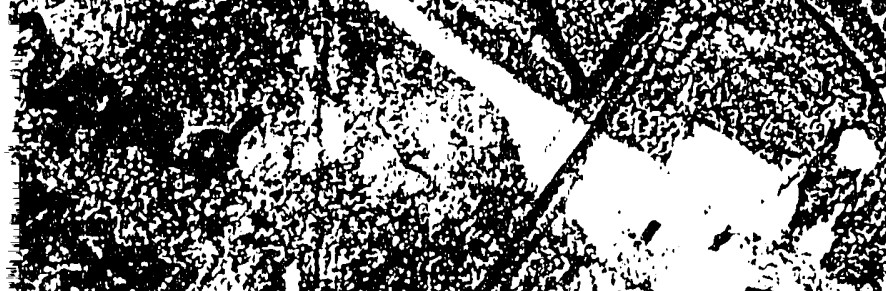
13.

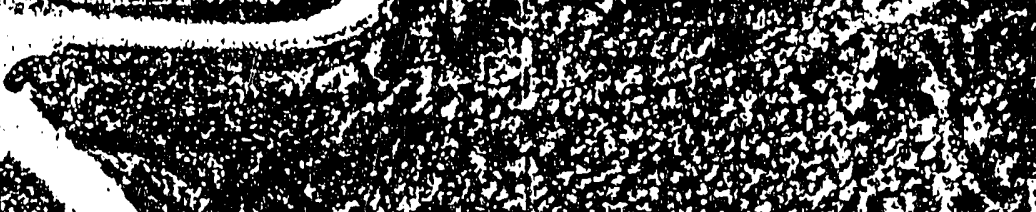

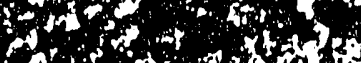
Ffsiving

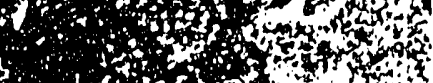
as (n)

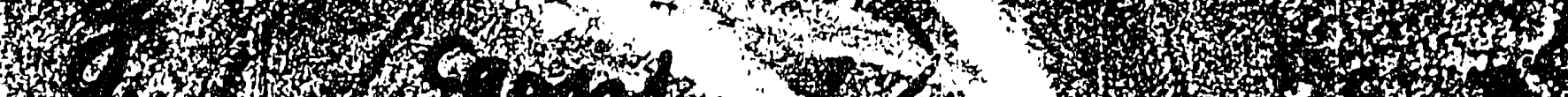

10

T.2

30

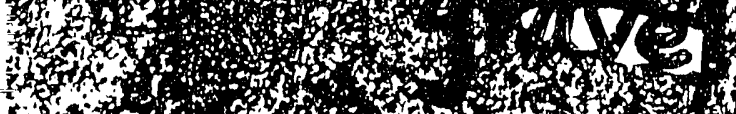

73y

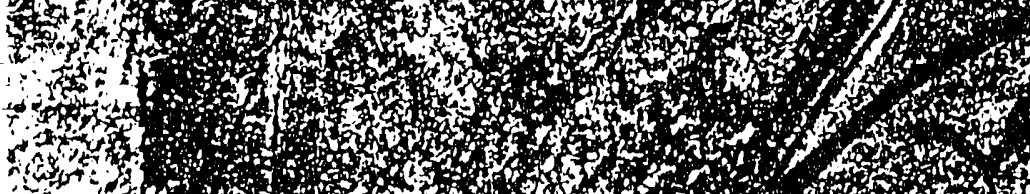

(1)

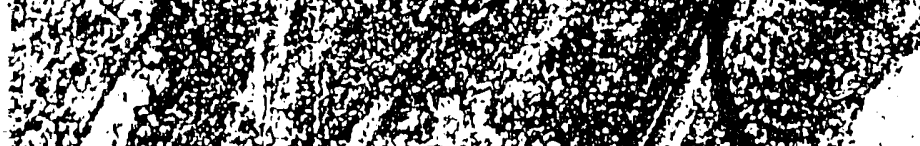

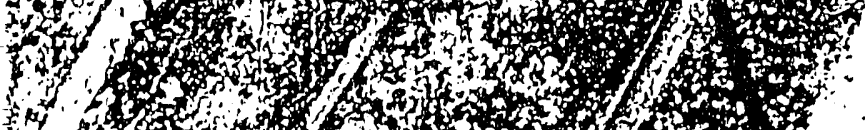

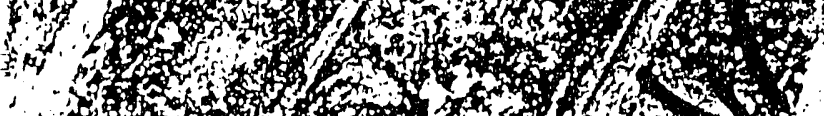

3.

mo

a s

Ho

然

4.

sistes 

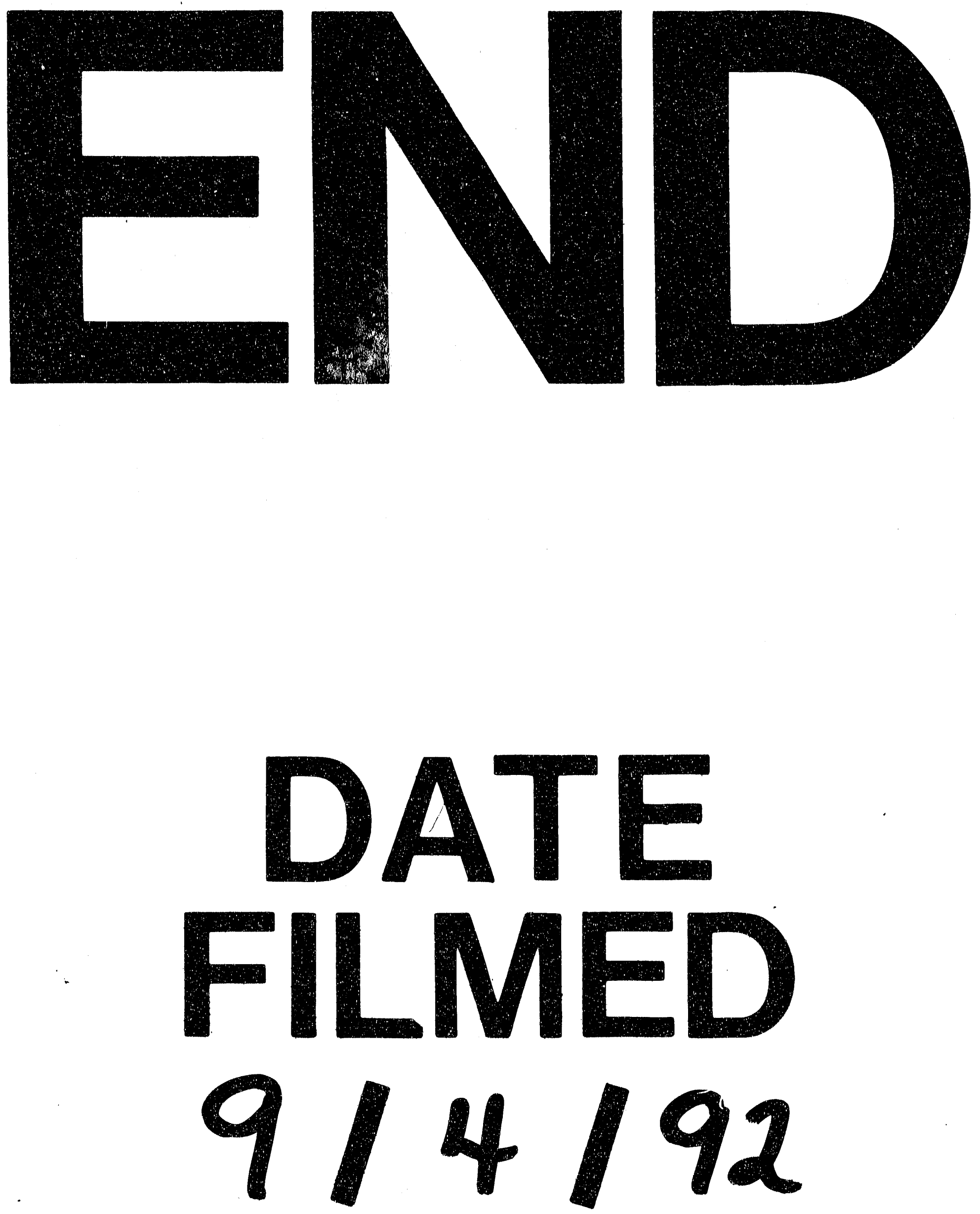
